\title{
Los ayubíes (564 h./1168-658 h./1260): un recorrido historiográfico
}

\section{The Ayyubids (564/1168-658/1260): a historiographical tour ${ }^{1}$}

\author{
Isabel CALLeJAS Martín \\ Licenciada por la Universidad Complutense de Madrid \\ isabel.callejas@gmail.com
}

Recibido: $29 / 06 / 2014$

Aceptado: 02/02/2015

\section{RESUMEN}

La historiografía sobre la dinastía ayubí ha experimentado un notable incremento a lo largo de los dos últimos siglos. Este trabajo pretende exponer un recorrido por los estudios publicados por los más destacados especialistas occidentales, además de una exhaustiva bibliografía.

Palabras clave: Historiografía, ayubíes, bibliografía, siglos XII-XIII.

\begin{abstract}
The historiography of the Ayyubid dynasty has been a notable increase grown significantly over the past two centuries. This work aims to present a tour of the studies published by leading Western specialists, along with a comprehensive bibliography.
\end{abstract}

Key words: Historiography, Ayyubids, Bibliography, $12 \mathrm{XII}^{\text {th }}-\mathrm{XIII} 13^{\text {th }}$ Centuries.

\footnotetext{
${ }^{1}$ El presente estudio es parte del Trabajo Académicamente Dirigido por el profesor del Departamento de Historia Medieval de la UCM. Dr. Martín Alvira Cabrer. 
El objetivo de este trabajo es presentar una panorámica de las investigaciones realizadas sobre la dinastía de los ayubíes por especialistas occidentales desde el siglo XIX hasta nuestros días. No conocemos una aportación similar en castellano (ni en otras lenguas), por lo que nos pareció interesante poner a disposición de estudiosos e interesados una amplia bibliografía comentada sobre esta importante etapa de la historia medieval islámica. El trabajo se compone de un recorrido historiográfico, un repertorio de bibliografía, tres apéndices y cuatro mapas ${ }^{2}$.

Los materiales manejados proceden de los fondos de la Biblioteca Nacional de España, la Casa de Velázquez y la Biblioteca Islámica de la Agencia Española para la Cooperación Internacional y el Desarrollo (AECID). También se han consultado portales de Internet, como los de la Bibliothèque Nationale de France, Persée, Mamluk Studies Resources -vinculado a The Middle East Documentation Center (MEDOC) de la Universidad de Chicago- o el Institut Français du Proche-Orient de Damasco (IFPO), entre otros.

La parte dedicada al estudio historiográfico está dividida en tres bloques. El primero corresponde al sigo XIX, época en que se publica el imprescindible Recueil des Historiens des Croisades, repertorio de traducciones al francés, casi siempre parciales, de obras de cronistas que vivieron las Cruzadas o que escribieron posteriormente sobre ellas. En el segundo bloque (1900-1970) se comentan las obras de los que podemos considerar precursores de la historiografía de la dinastía ayubí: Hamilton Gibb, Hans Ludwig Gottschalk, Emmanuel Sivan y, sobre todo, Claude Cahen. Entre 1970 y 2014 se produce un incremento de los estudios y comienzan a celebrarse congresos específicos sobre este periodo del Islam medieval. Dada la variedad de temas estudiados, esta última parte se ha organizado en epígrafes temáticos. Aunque el propósito del trabajo es recoger publicaciones originales, hemos considerado oportuno dedicar el primer epígrafe a las traducciones de las principales fuentes islámicas, imprescindibles para el estudio de los ayubíes. En los siguientes se relacionan los estudios de los expertos occidentales. Hemos procurado ubicar cronológicamente a cada uno de los autores, aunque algunas fechas de nacimiento nos han sido imposibles de determinar. Tampoco hemos podido conocer los directores de algunas tesis doctorales, dato que para el resto se indica sistemáticamente.

En el segundo apartado se incluye una bibiografía, en la que hemos reflejado todos los trabajos que hemos podido encontrar, además de las fuentes.

Tres apéndices componen la tercera parte. En el primero presentamos una relación de los principados ayubíes y sus dirigentes. Para su confección hemos partido de la monografía de Robert Stephen Humphreys, From Saladin to the Mongols, añadiendo al año de la Hégira el correspondiente a nuestro calendario para su mejor localización temporal. Aunque no tuvieron demasiada influencia en la historia familiar también incluimos a los gobernantes de Yemen. El segundo apéndice es un árbol genealógico, realizado a partir de los datos encontrados en el citado trabajo de Humphreys y en la obra The Mohammedan Dinasties de Stanley Lane-Poole. Hemos introducido, junto

\footnotetext{
${ }^{2}$ Quiero expresar mi agradecimiento a Anne-Marie Eddé, Maribel Fierro y Yaacov Lev por el interés que han mostrado en este estudio, su inestimable colaboración al resolver dudas y cuestiones idiomáticas y sus sugerencias. Agradezco también a los evaluadores anónimos de En la España Medieval sus comentarios y sugerencias.
} 
a cada príncipe, los territorios y años de su gobierno. De esta forma podemos comprobar cómo los principados fueron pasando de una rama familiar a otra.

El estudio se completa con cuatro mapas de autoría propia. El primero señala la situación de las principales ciudades de los actuales Turquía, Siria, Jordania, Israel y Líbano que pertenecieron en algún momento a los príncipes ayubíes. Otros dos recogen los límites del Sultanato en Siria y Palestina en el momento de la muerte de Saladino y tras la expansión territorial de al-'Ādil. En un cuarto mapa se muestran tres zonas de la región de Jazira mencionadas frecuentemente por los cronistas, pero no siempre fáciles de localizar: Diyār Muḍar, Diyār Bakr y Diyār Rabī‘ah.

\section{ABREVIATURAS UTILIZADAS}

$A I$

$B E O$

$B S O A S$

ES I

ES II

ES III

ES IV

$E S V$
$A M$

Annales Islamologiques

Al Masaq

\section{Bulletin d'Études Orientales}

Bulletin of the School of Oriental and African Studies

Vermeulen, U. y De Smet, D. (eds.), Egypt and Syria in the Fatimid, Ayyubid and Mamluk Eras: Proceedings of the $1^{\text {st }}, 2^{\text {nd }}$ and $3^{\text {rd }}$ International Colloquium organized at the Katholieke Universiteit Leuven (May 1992, 1993 and 1994), Lovaina, Uitgeverij Peeters, 1995.

Vermeulen, U. y De Smet, D.D. (eds.), Egypt and Syria in the Fatimid, Ayyubid and Mamluk Eras II: Proceedings of the $4^{\text {th }}$ and $5^{\text {th }}$ International Colloquium organized Colloquium organized at the Katholieke Universiteit Leuven (May 1995 and 1996), Lovaina, Uitgeverij Peeters, 1998.

Vermeulen, U. y Van Steenbergen, J. (eds.), Egypt and Syria in the Fatimid, Ayyubid and Mamluk Eras III: Proceedings of the $6^{\text {th }}$, $7^{\text {th }}$ and $8^{\text {th }}$ International Colloquium organized at the Katholieke Universiteit Leuven (May 1997, 1998 and 1999), Lovaina, Uitgeverij Peeters, 2001.

Vermeulen, U. y Van Steenbergen, J. (eds.), Egypt and Syria in the Fatimid, Ayyubid and Mamluk Eras IV: Proceedings of the $9^{\text {th }}$ and $10^{\text {th }}$ International Colloquium organized at the Katholieke Universiteit Leuven (May 2000 and 2001), Lovaina, Uitgeverij Peeters, 2005. Vermeulen, U. y D'hulster, K. (eds.), Egypt and Syria in the Fatimid, Ayyubid and Mamluk Eras V: Proceedings of the $11^{\text {th }}, 12^{\text {th }}$ and $13^{\text {th }}$ International Colloquium organized at the Katholieke Universiteit Leuven (May 2002, 2003 and 2004), Lovaina, Uitgeverij Peeters, 2008.

ES VI Vermeulen, U. y D'hulster, K. (eds.), Egypt and Syria in the Fatimid, Ayyubid and Mamluk Eras VI: Proceedings of the $14^{\text {th }}$ and $15^{\text {th }}$ 
International Colloquium organized at the Katholieke Universiteit Leuven (May 2005 and 2006), Lovaina, Uitgeverij Peeters, 2010.

IJKS International Journal of Kurdish Studies

JAOS Journal of American Oriental Society

MSR Mamluk Studies Review

REI Revue des Études Islamiques

\section{LA HISTORIOGRAFÍA DEL SIGLO XIX}

En este siglo encontramos pocas obras referentes al tema que nos ocupa, escritas en su mayoría por autores franceses. En 1824 Joseph Toussaint Reinaud (1795-1867) publica una pequeña biografía de cuarenta páginas sobre Saladino ${ }^{3}$. En 1872 aparece el primer volumen del famoso e importantísimo Recueil des Historiens des Croisades ( $R H C$ ), publicado por l'Académie des Inscriptions et Belles-Lettres. Se trata de una gran recopilación de crónicas y documentos medievales relativos a las Cruzadas. Esta obra facilitó nuevas vías de investigación a los historiadores posteriores. En la serie Historiens Orientaux, se tradujeron extractos de algunas crónicas árabes correspondientes al periodo ayubí ${ }^{4}$. Se encuentra aquí parte de la obra de Abū l-Fidā' (12731331), un historiador descendiente de Taqī l-Dīn 'Umar, cuya obra histórica en forma de anales, parcialmente publicada por Rieske en 1754, fue durante mucho tiempo la crónica musulmana de la época más conocida en Occidente $^{5}$. En el mismo volumen se recogen extractos de la obra de Ibn al-Ațīr (1160-1233), el célebre cronista sirio que acompañó al ejército de Saladino. El segundo tomo ofrece, en su primera parte, la continuación de la misma crónica y, en la segunda, otro de sus escritos en el que relata sus propias vivencias y las de su padre, un alto oficial de Nūr al-Dīn ${ }^{6}$. En el tercer volumen se incluye la traducción de la crónica de Bahā' l-Dīn ibn Šaddād (1145-1234), jurista muy cercano a Saladino, que fue testigo presencial de muchos de los hechos que narra? . En los volúmenes cuarto y quinto encontramos las biografías de Nūr alDīn y Saladino escritas por Abū Šāma (1203-1267), cronista de Damasco, en las que utilizó una gran cantidad de documentación oficial ${ }^{8}$.

Unos años más tarde, Hartwig Derenbourg (1844-1908), profesor de árabe y religión musulmana en la École Pratique des Hautes Études de París y autor de nume-

\footnotetext{
${ }^{3}$ Reinaud, J.t., Notice sur la vie de Saladin, sultan d'Egypte et de Syrie, París, Dondey Dupré, 1824.

${ }^{4}$ Recueil des Historiens des Croisades. Historiens Orientaux, 5 vols., París, Académie des Inscriptions et Belles-Lettres, 1872-1906 [en adelante RCH.HO].

${ }^{5}$ ABŪ L-FidĀ', Mukhtașar tā'rīkh al-Bashar ("Historia concisa de la Humanidad"), en RHC.HO, vol. I, pp. 1-163.

${ }^{6}$ IBN Al-AT̄īr, Al-Kāmil fi l-Ta'rīkh (“La historia completa”), en RHC.HO, vol. I, pp. 190-744 y vol II, pp. 3-180; Al-Tārīkh al-bāhir fì al-Dawlah al-Atābakīyah bi-al-Mawșil ("Crónica de los atabegs de Mosul”), en RHC.HO, vol. II-2, pp. 6-375.

${ }^{7}$ BAHA' L-Dīn, Al-Nawādir al-Sultāniyya wa 'l-Mahāsin al-Yūsufiyya (“Anécdotas y virtudes del sultán Yusuf"), en RHC.HO, vol. III, pp. 4-430.

${ }^{8}$ AвŪ Š̀̄ma, Kitāb al-Rawdatain fi Akhbār al-Dawlatain ("Libro de los dos jardines, historia de dos reinos"), en RHC.HO, vol. IV, pp. 4-522 y vol. V, pp. 4-206.
} 
rosas ediciones de documentos islámicos, publicó la primera traducción de la autobiografía del conocido noble sirio Usāma ibn Munqid (1138-1188). Es reseñable que Derenbourg realizara su trabajo partiendo de un manuscrito original que encontró en la Biblioteca de El Escorial ${ }^{9}$.

A mediados del siglo, encontramos los primeros estudios escritos en lengua inglesa. Entre 1843 y 1871, William MacGuckin de Slane (1801-1878) publica la traducción en cuatro tomos de la obra más conocida de Ibn Jallikān Kitāb wafayāt al-a yyān wa anbā' abnā' al-zamān ${ }^{10}$. Ibn Jallikān (1211-1282) fue un jurista, teólogo y gramático de origen iraquí, que tuvo importantes cargos en Damasco y El Cairo. En 1889 aparece la obra dedicada a Saladino de Stanley Lane-Poole (1854-1931), un arqueólogo y orientalista británico, profesor de árabe en el Trinity College de Dublín entre 1897 y $1904^{11}$. Se trata de una biografía, escrita a partir de un número importante de fuentes islámicas, en la que presenta al sultán como un hombre de gran nobleza y caballerosidad, algo muy propio del momento, dada la visión romántica de la época y la gran influencia que tuvo en ese sentido la célebre novela El Talismán de Walter Scott $^{12}$. En estos años, se publica un trabajo de Guy Le Strange (1854-1933), un destacado orientalista inglés, que podemos considerar pionero en la geografía histórica del Próximo Oriente, Palestine Under the Moslems: A Description of Syria and the Holy Land from A.D. 650 to $1500^{13}$.

\section{EL SIGLO XX HASTA 1970}

Durante los primeros años del siglo los estudios sobre los ayubíes son escasos, si bien la producción se va incrementando lentamente hasta llegar a los 70, cuando se producirá un aumento notable. Celestino Schiaparelli (1841-1919) publica en 1906 la traducción al italiano del Riḥla de Ibn Ŷbayr ${ }^{14}$. La traducción francesa de Maurice Gaudefroy-Demombynes (1862-1957) aparece en cuatro volúmenes entre 1949 y $1965^{15}$. Ibn Ŷubayr (1145-1217) fue un geógrafo y poeta andalusí que escribió este libro de viajes durante su peregrinación a La Meca entre 1183 y 1185, en el que describe, entre otras, las tierras que en aquel momento gobernaba Saladino. En 1929 Philip Khuri Hitti publica una nueva traducción de las memorias de Usāma ibn Munqid. Hitti (1886-1978) fue profesor en diversas universidades norteamericanas. Pode-

\footnotetext{
${ }^{9}$ Derenbourg, H., Ousama ibn Munqidh, un emir syrien au premier siècle des Croisades (1095-1188), Paris, Leroux, 1889.

${ }^{10}$ De Slane, M.g., Ibn Khallikan's Biographical Dictionary, (Kitāb wafayāt al-a 'yān wa anbā' abnā' alzamān), 4 vols., Paris-Londres, Oriental Translation Found, 1843-1871.

${ }^{11}$ Lane-Poole, S., Saladin and the Fall of the Kingdom of Jerusalem, Londres, G.P. Putnam's Sons, 1898.

12 Scott, W., The Talisman, Londres, Archibald Constable, 1825.

${ }^{13}$ Le Strange, G., Palestine Under the Moslems: A Description of Syria and the Holy Land from A.D. 650 to 1500, Londres, A.P. Watt, 1890.

${ }^{14}$ Schiapareldi, C., Viaggio in Ispagna, Sicilia, Siria e Palestina, Mesopotamia, Arabia, Egitto, compiuto nel secolo XII, Roma, Casa editrice italiana, 1906

${ }^{15}$ Gaudefroy-Demombynes, M., Voyages, “Rihlla”, Ibn Jubayr, 4 vol., Paris, P. Geuthner, 1949-1965.
} 
mos considerarle, además, el iniciador de los estudios islámicos en Estados Unidos ${ }^{16}$. En 1933, Johannes Hartmann defiende su tesis doctoral en la Universidad de Jena. En ella aborda la personalidad de Saladino a la luz de las fuentes ${ }^{17}$. La primera obra totalmente dedicada a otro miembro de la dinastía es otra tesis, defendida en París en 1939 por el egipcio Kamil Ismail, si bien este historiador no continuó trabajando en este campo, pues se especializó en el estudio de edificios religiosos y del folklore egipcios $^{18}$.

Pocos años después comenzó a publicar Hamilton Gibb (1895-1971), orientalista escocés y uno de los editores de la primera edición de la Encyclopaedia of Islam ${ }^{19}$. En 1950 llegó a Harvard como profesor visitante, dirigiendo después el Harvard Center for Middle Eastern Studies y destacando como uno de los impulsores del movimiento destinado a constituir centros de investigación regional en los campus norteamericanos. Sus trabajos sobre literatura árabe y traducción de crónicas le llevaron a escribir una biografía de Saladino basada en las obras de Bahā' l-Dīn e 'Imād al-Dīn, así como varios artículos sobre los ejércitos y las fuentes musulmanas. Además es autor de un capítulo de la célebre Historia de las Cruzadas publicada por la Universidad de Wisconsin bajo la dirección de Kenneth M. Setton ${ }^{20}$.

Una personalidad imprescindible en la historiografía de los ayubíes es Claude Cahen (1909-1991), medievalista francés que dedicó sus primeros trabajos al Occidente europeo para especializarse después en la historia de Siria y el principado latino de Antioquía en la Plena Edad Media. Podemos considerarle un pionero por su forma de enfocar de una manera novedosa los estudios sobre el mundo islámico medieval. Según Bernard Lewis, hasta entonces la historia del Islam de los siglos XII y XIII había sido escrita por dos grupos de investigadores occidentales: los filólogos, cuyos intereses eran literarios, lingüísticos o teológicos; y los que veían el Oriente Latino como una prolongación de Europa y a los musulmanes únicamente como el enemigo. Cahen fue el primer historiador de una nueva tendencia: la que comenzaron a seguir estudiosos que volcaron su atención en el Mediterráneo oriental con el mismo espíritu y los mismos medios que utilizaban para el estudio de cualquier parte de Europa, historiadores que asumían que, por ejemplo, si se quería estudiar la historia de Alemania, era necesario conocer el idioma alemán. En este sentido, el árabe fue siempre un obstáculo, y es relativamente reciente la aparición de una nueva generación de especialistas en el Próximo Oriente medieval bien preparados lingüísticamente. Cahen fue uno de los pioneros de esta aproximación, pues formó historiadores en Europa, Oriente Medio y África del Norte y, como los grandes eruditos, abrió nuevos caminos

${ }^{16}$ Hiтti, P.к., An Arab-Syrian Gentleman and warrior in the Period of the Crusades, Memoirs of Usāmah Ibn Munqidh, Nueva York, Columbia University Press, 1929.

${ }^{17}$ Hartmann, J., Die Persönlichkeit des Sultans Saladin im Urteil der abendländischen Quellen, Tesis Doctoral, Universität Jena, 1933; pub. Berlín, Verlag E. Ebering, 1933.

${ }^{18}$ Ismail, K., La biographie du sultan ayyoubide al-Malik al-Kamil, 615-635 de l'Hégire (1218-1238), Tesis Doctoral, Université Sorbonne, 1939.

${ }^{19}$ GiBB, H., et al. (eds.), Encyclopaedia of Islam, 4 vols., Leiden, Brill (1913-1936).

${ }^{20}$ GibB, H., "The Ayyubids", en Setton, K.м. (ed.), A History of the Crusades, 5 vols., Madison, University of Wisconsin Press, 1955, vol. II., pp. 693-714; y The Life of Saladin from the Works of Imad al-Din and Baha al-Din, Oxford, Clarendon Press, 1973. 
para futuras investigaciones ${ }^{21}$. Publicó numerosos estudios sobre diversos aspectos de la dinastía ayubí que comentaremos en los apartados correspondientes, aunque, sin duda, sus obras más destacables son La Syrie du Nord à l'époque des Croisades et la principauté franque d'Antioche (1940) y Orient et Occident au temps des Croisades $(1983)^{22}$.

Junto a estas tres personalidades, cabe destacar en Europa al alemán Hans Ludwig Gottschalk (1904-1981), profesor de árabe y estudios islámicos en la Universidad de Viena. En 1958 escribió una biografía del sultán al-Kāmil, además de traducir diversos manuscritos ${ }^{23}$.

Tras la constitución del Estado de Israel, los estudiosos de la Universidad Hebrea de Jerusalén comenzaron sus investigaciones sobre la historia judía y, por proximidad, también sobre la musulmana. Entre ellos destaca la figura de Emmanuel Sivan (1937), doctor en Historia por la Sorbona y profesor en varias universidades europeas y norteamericanas. Es especialista en el Islam y autor de diversos libros y artículos sobre el fundamentalismo y la política en Oriente Próximo. Su principal contribución a la historia de los ayubíes son dos capítulos de su obra L'Islam et la croisade. Idéologie et propagande dans les réactions musulmanes aux croisades $(1968)^{24}$.

\section{DE 1970 HASTA NUESTROS DÍAS}

La bibliografía sobre los ayubíes aumenta considerablemente en el último tercio del siglo pasado. Se tratan temas poco estudiados hasta entonces, como las biografías de los personajes menos conocidos de la dinastía. Se da una gran producción de trabajos sobre temas militares, especialmente en lo referente a fortificaciones, gracias a la contribución de los investigadores del Institut Français du Proche-Orient de Damasco (IFPO). Otro aspecto significativo es la celebración de congresos dedicados específicamente al Islam medieval.

Los estudiosos franceses continúan siendo los más activos en estos años. Podemos citar a Dominique Sourdel (1921), especialista en el Califato abasí y las instituciones políticas islámicas y maestro de historiadores que trabajarán más tarde sobre los ayubíes. Otra personalidad destacada es Janine Sourdel-Thomine (1925), experta en arte y epigrafía árabes, así como en el estudio de la mentalidad y la religiosidad popular islámicas en el siglo XII ${ }^{25}$. 220.

${ }^{21}$ Lewis, B., “Claude Cahen”, Proceedings of the American Philosophical Society, 141/2 (1977), pp. $217-$

${ }^{22}$ CAHen, C., La Syrie du Nord à l'époque des Croisades et la principaute franque d'Antioche, París, Paul Geuthner, 1940; y Orient et Occident au temps des Croisades, París, Aubier Montaigne, 1983.

${ }^{23}$ Gottschalk, H.L., Al-Malik al-Kamil von Egypten und seine Zeit: eine Studie zur Gestichte Vorderasiens und Egyptens in der ersten Hälfte des 7/13 Jahrhunderts, Weisbaden, O. Harrasowitz, 1958.

${ }^{24}$ Sivan, E., "L'apogée: Saladin (1174-1189)", en Sivan, E., L'Islam et la croisade, idéologie et propagande dans les reactions musulmans aux Croisades, París, Adrien Maisonneuve, 1968, pp. 93-130; y "Détente et opposition (1193-1260)", ibidem, pp. 131-165.

${ }^{25}$ Entre sus trabajos podemos destacar "L'état ayyoubide vu par un homme de réligion de cette époque", Israel Oriental Studies, 10 (1980), pp. 124-131. 
Unos años después encontramos a Anne-Marie Eddé, discípula de Claude Cahen. Se especializó en textos árabes de la época de las Cruzadas (ss. XII-XIII) y, en general, en la historia del Próximo Oriente medieval. Su tesis doctoral, leída en 1995, es un estudio del Alepo ayubíi ${ }^{26}$. Ha investigado aspectos militares, económicos, demográficos, etc. de ésta época y es autora de una reciente biografía de Saladino a la que ha dedicado casi diez años de trabajo ${ }^{27}$.

Aunque los estudiosos franceses seguirán siendo los más dedicados al periodo ayubí, en el último tercio del siglo XX se encuentra un número cada vez mayor de autores de otras nacionalidades que publican trabajos sobre aspectos muy variados del Próximo Oriente medieval. Por ello, hemos creído conveniente organizarlos a partir de ahora en apartados temáticos.

\section{Crónicas traducidas}

Además de las publicadas en el célebre Recueil des Historiens des Croisades, se han traducido algunas crónicas y obras de la época ayubí. Claude Cahen dedicó buena parte de su vida a la traducción de crónicas árabes, publicando ediciones y traducciones parciales de las más importantes. Así encontramos el tratado del experto militar al-Ṭarsūsī, escrito para Saladino, o extractos de la obra dedicada al sultán al-Șāliḥ por Ibn Wāșil, historiador muy cercano a los príncipes ayubíes, que fue testigo de la caida de la dinastía y la ascensión al poder de los mamelucos ${ }^{28}$.

Contamos con una traducción parcial de la historia escrita por Ibn al-Furāt a cargo de Ursula y Cameron Lyons y Jonathan Riley-Smith, publicada en 1971. Ibn al-Furāt (1334-1405) fue un historiador y erudito egipcio cuya obra se centra especialmente en las Cruzadas ${ }^{29}$. En 1972 se publica la traducción al francés de Henri Massé (18861969) de la obra de 'Imād al-Dīn al-Ișfahānī (1125-1201), titulada Kitāb al-fath alqussī fì l-fath al-quds $\bar{l}^{30}$. 'Imād al-Dīn fue un jurista que se instaló en Damasco en 1167. Debido a su trabajo en la cancillería se integró en el círculo íntimo de Nūr al-Dīn. Tras la muerte del sultán, encontró un nuevo protector en Saladino, algo que se le reprochó como una traición al heredero legítimo, al-Ṣāliḥ Ismā'îl, hijo de Nūr alDīn. Lo cierto es que 'Imād al-Dīn mantenía desde hacía tiempo una estrecha amistad con Naŷm al-Dīn Ayyūb y su hermano Šīrkūh, padre y tío de Saladino, respectivamente. 'Imād al-Dīn acompañó al sultán en casi todas sus expediciones, siendo testigo de la batalla de Hattin y la reconquista de Jerusalén. Massé, editor de su obra, fue un orientalista francés, profesor de literatura árabe y persa en la Universidad de

${ }^{26}$ EDDÉ, A.M., La principauté ayyoubide d'Alep (579/1183-658/1260), Tesis Doctoral, dir. Dominique Sourdel, Université Sorbonne-Paris IV, 1995; pub. Stuttgart, Franz Steiner Verlag, 1999.

${ }^{27}$ EDDÉ, A.M., Saladin, París, Flammarion, 2008.

${ }^{28}$ CAHEN, C., "Un traité d'armurerie composé pour Saladin", ed. y trad. parciales de Tabsirat arbāb al-al$b \bar{a} b$ de al-Tarsūsī, $B E O, 12$ (1947-48), pp. 103-163; "Une source pour l'histoire des croisades: les mémoires de Sa ‘d ad-Dīn Ibn Hamawiya Juwaīni”, Bulletin de la Faculté des Lettres de Strasbourg, 28/7 (1950), pp. 320337; y "Sur le Ta'rīkh Sālihī d'Ibn Wāsil. Notes et extraits", en Sharon, M. (ed.), Studies in Islamic History and Civilization in Honour of Professor David Ayalon, Leiden, Brill, 1986, pp. 507-516.

${ }^{29}$ Lyons V., Lyons, M.c. y Riley Smith, J.s.c., Ayyubids, Mamluks and Crusaders. Selections from the Tārīkh al-Duwal wa'l-Mulūk of Ibn al-Furāt, 2 vols., Cambridge, W. Heffer and Sons, 1971.

${ }^{30}$ Massé, H., Conquête de la Syrie et de la Palestine par Saladin, "Kitāb al-fath al-qussì fì l-fath alqudsī”, Imād al-Dīn al-Isfahāni, París, Académie des Inscriptions et Belles-Lettres, 1972. 
Argel y administrador entre 1927 y 1958 de la École Nationale des Langues Orientales Vivantes de París (ENLOV), actual Institut National des Langues et Civilisations Orientales (INALCO).

En 1980, Roland Broadhurst publicó la traducción de la obra de al-Maqrīzī que tituló A History of the Ayyubid Sultans of Egypt ${ }^{31}$. Al-Maqrīzī (1364-1442) fue un hombre de leyes y estaba especialmente interesado en el papel que desempeñó en la historia de Egipto la dinastía fatimí. El texto utilizado por Broadhurst es la parte dedicada a los ayubíes del Kitāb al-sulūk li-ma'rifat duwal al-mulūk. R. Stephen Humphreys apuntó en una reseña que ya existían traducciones anteriores de esta obra y que una de las fundamentales para conocer la historia de las cuatro décadas siguientes a la muerte de al-'Ādil en 1218, Mufarrî̀ al-kurūb fi akhbār Bañ̄ Ayyūb de Ibn Wāṣil, seguía sin traducirse totalmente a ninguna lengua occidental en 1983 (tampoco en la actualidad). Humphreys opinaba que Broadhurst podía haber utilizado los originales que se encuentran en la Bibliothèque nationale de France de París, en lugar de trabajar sobre algo ya conocido ${ }^{32}$.

En nuestro país destacaremos la traducción del libro de viajes, Rihla, de Ibn Ŷubayr a cargo del profesor de Estudios Árabes e Islámicos de la Universidad de Salamanca, Felipe Maíllo Salgado ${ }^{33 .}$

Françoise Micheau también se ha dedicado a la traducción de crónicas. Es profesora de la Universidad de París I, directora del Laboratoire Islam Médiéval y del grupo de investigación Orient et Méditerranée. Sus líneas de trabajo son la historia social y cultural del Próximo Oriente medieval, la transmisión a Occidente de la medicina árabe, las relaciones Islam-Cristiandad y la historia de las comunidades cristianas en países islámicos. Publicó junto a Anne-Marie Eddé la traducción de la Chronique des Ayyoubides de al-Makīn b. al- 'Amīd según las directrices del maestro Claude Cahen ${ }^{34}$. Como podemos leer en la introducción de la obra, éste relacionó una serie de autores cuya traducción consideraba indispensable. Además de al-Makīn, recomendaba que se tradujeran las crónicas de Ibn Abī Tayyi’, Ibn Naẓîf, Kamāl alDīn b. al-'Adīm, Sibṭ al-Ŷ̀awzī e Ibn Wāși ${ }^{35}$. El gran especialista ya había iniciado esta tarea, pero su avanzada edad y su pérdida de visión hicieron que delegara en sus discípulas más destacadas.

La crónica de Ibn Wāșil ha sido estudiada parcialmente por Mohamed Rahim en su tesis doctoral, leída en 2006 en la Universidad de Jena y publicada en $2010^{36}$. Ŷamāl al-Dīn ibn Wāṣil (1208-1298) fue un jurista sirio perteneciente a la escuela šăfíī que

${ }^{31}$ Broadhurst, R.J.C., A History of the Ayyubid Sultans of Egypt translated from the Arabic of al-Maqrizi, Boston, Twayne, 1980.

${ }^{32}$ Humphreys, R.s., "Broadhurst, R.J.C. A History of the Ayyubidd Sultans of Egypt translated from the Arabic of al-Maqrizi, Boston, Twayne, 1980”, Reseña, JAOS, 103/2 (1983), pp. 449-452.

${ }^{33}$ Maíllo Salgado, F., A través del Oriente: el siglo XII ante los ojos, Barcelona, Ediciones del Serbal, 1988; reed. 2007

${ }^{34}$ Eddé, A.m. y Micheau, F., Chronique des Ayyoubides de al-Makin ibn al- 'Amīd (602-658/1205-1260), París, Académie des Inscriptions et Belles-Lettres, 1994.

${ }^{35}$ CAHEN, C., "Pour un programme de traductions des chroniques arabes du Proche-Orient au temps des croisades", Journal des Savants, 1 (1987), pp. 13-26.

${ }^{36}$ Rahim, M., Die Chronik des Ibn Wasil, kritische Edition des letzten Tells (646/1248-659/1261) mit Kommentar; Untergand der Ayyubiden und Beginn der Mamlukenherrschaft. "Mufarrig al-kurub fi ahbar Bani 
ocupó puestos relevantes en Egipto y en su ciudad natal, Hama. Su obra más importante es el citado Mufarriŷ, que comprende los últimos años de Zangī, la totalidad del periodo ayubí y los primeros tiempos de los mamelucos en Siria y Egipto. Un autor muy estudiado por los historiadores franceses es Sibṭ al-Ŷawzī (¿1186?-1256), un religioso e historiador muy próximo a los ayubíes de Damasco, especialmente a al-Mu'azzam 'Īsā. Su obra titulada Mir'āt al-Zamān fì Ta'rīj al-A 'yān, fue objeto de estudio y traducida por parte de Salwa Sayde-Hajjar y Frédéric Monot en sus tesis doctorales ${ }^{37}$.

En 1994, David Morray, profesor de Árabe e Historia islámica en el University College de Dublín, publicó una traducción del diccionario biográfico de notables de Alepo, Bugyat al-talab fì ta' 'rij Halab, de Ibn al-'Adīm (1192-1262), miembro de una prestigiosa familia alepina, director de una madrasa y diplomático ${ }^{38}$.

Donald Sidney Richards (1935), profesor emérito del Instituto Oriental de la Universidad de Oxford, publica en 1993 la traducción al inglés de la última parte de la obra de Ibn Abī l-Damm Kitāb al-šamārīh fì l-tawārīj, conservada parcialmente en la Bodleian Library. Ibn Abī l-Damm (1187-1244) fue un jurista y diplomático de Hama, testigo de los sucesos de la Sexta Cruzada que se narran en este estudio $^{39}$. Posteriormente, Richards tradujo la obra de Bahā' 1-Dīn titulada al-Nawādir al-Sultāniyya wa-l-Mahāsin al-Yūsufiyya, que tituló The Rare and Excelent History of Saladin. Bahā' l-Dīn ibn Šaddād gozaba de la confianza de Saladino y fue juez del ejército ayubí desde 1188 hasta la muerte del sultán en 1193. Es, por tanto, una fuente esencial para conocer la historia de Egipto y del Próximo Oriente de la época, y complementa las muy conocidas crónicas del Reino Latino de Jerusalén ${ }^{40}$. También ha traducido la obra de Ibn al-Atīir (1160-1233), miembro de una familia de burócratas al servicio de Nūr al-Dīn. En 1188 pasó algún tiempo en Siria y fue testigo de las campañas de Saladino, aunque no hay constancia de que tuviesen contacto personal. En Mosul, donde vivió la mayor parte de su vida, trabajó bajo la protección del atabeg Badr al-Dīn Lu'lu'. En esta ciudad, que no fue atacada por los mongoles, murió en 1233. Richards divide su obra, al-Kāmil fì l-Ta'rîj, en tres periodos. Los dos últimos son los correspondientes a la época que nos ocupa: la de Nūr al-Dīn y Saladino y la posterior, desde la muerte del sultán hasta la llegada de los mongoles ${ }^{41}$.

Ayyub", Tesis Doctoral, dir. Tilman Seidensticker, Friedrich Schiller Universität Jena, 2006; pub. Die Chronik des Ibn Wasil, Wiesbaden, O.Harrasowitz, 2010.

${ }^{37}$ Sayde-HaJjar, S., Mir'at al-Zaman fi Ta'rikh al-A 'yan, traduction annotée (589-1193 à 654-1256), Tesis Doctoral, dir. Claude Cahen, Université Paris-Sorbonne I, 1982; у МоNoт, F., L'Orient islamique au $V I^{e}$-XII siècles à travers le "Mir'at al-Zaman fi Ta'rikh al-A yan", traduction annotée sur les annés 518569/1124-1175, Tesis Doctoral, dir. Dominique Sourdel, Université Paris-Sorbonne IV, 1992.

${ }^{38}$ Morray, D., An Ayyubid Notable and His World: Ibn al- 'Adim and Aleppo as Portrayed in His Biographycal Dictionary, "Bughyat al-talab fi ta'rik Halab”, Leiden, Brill, 1994.

${ }^{39}$ Richards, D.s., "The Crusade of Frederick II and the Hamāh Succesion. Extracts from the Chronicle of Ibn Abi l-Damm, Kitāb al-šamārīh fì l-tawārīj”’, BEO, 45 (1993), pp. 183-200.

${ }^{40}$ Richards, D.S., The Rare and Excelent History of Saladin or "al-Nawadir al-Sultaniyya wa'l-Mahasin al-Yusufiyya", Farham, Ashgate, 2002.

${ }^{41}$ Richards, D.S., The Chronicle of Ibn al-Atīir for Crusading Period from "al-Kamil fi l-Ta'rikh". Part. II: The Years 541-589/1146-1193: The Age of Nur al-Din and Saladin, Farham, Ashgate, 2010; y Part. III: The Years 589-629/1193-1231: The Ayyubids after Saladin and the Mongol Menace, Farham, Ashgate, 2010. 
Finalmente, encontramos una traducción de fuentes no árabes. Ephrem-Isa Youssif (1944), historiador iraquí, profesor de Literatura, Filosofía y lengua árabes en la Universidad de Toulouse, ha traducido las crónicas de autores sirios que hacen referencia en sus escritos a Saladino y los ayubíes, como el Anónimo de Edesa, Miguel el Sirio o Bar Hebraeus ${ }^{42}$.

\section{Biografias de sultanes}

Saladino fue el protagonista casi exclusivo de las obras biográficas sobre los ayubíes hasta finales del siglo XX. En 1972, Andrew Ehrenkreutz (1921-2008) publicó Saladin, un estudio que ofrecía una visión del sultán totalmente distinta a la habitual. No mencionaba apenas las guerras contra los cruzados, sino su ascensión al poder, llegando a la conclusión de que no era el enemigo caballeroso que refleja la leyenda occidental $^{43}$. Esta obra suscitó una gran polémica. El profesor Hans Eberhard Mayer (1932), un experto internacional en las Cruzadas, criticó en una reseña a Ehrenkreutz por utilizar términos modernos como "guerra química" o blitzkrieg en un contexto medieval, así como por mencionar bibliografía no consultada y por omitir hechos constatados de la vida del sultán ${ }^{44}$. Desde entonces, han aparecido numerosos trabajos sobre la vida del fundador de la dinastía ayubí. Uno de los más recientes es el publicado por Anne-Marie Eddé, una obra de gran calado en la que maneja un número muy importante de fuentes árabes no traducidas a fin de esclarecer la personalidad de Saladino. Esta especialista analiza el discurso que le presenta como adalid de la fe y llega a conclusiones interesantes, como que uno de sus mayores éxitos fue la imagen que creó de sí mismo o la dificultad del historiador moderno para distinguir al hombre devoto del político astuto ${ }^{45}$.

Una novedad importante es la aparición en el último tercio del siglo XX de obras sobre los ayubíes menos conocidos. Uno de los principales, al-'Ādil, fue estudiado en la tesis doctoral, leída en 1975, del alemán Franz-Josef Dahlmanns ${ }^{46}$. También Claude Cahen publicó un pequeño trabajo en 1977 sobre el testamento de al-Ṣālih Ayyūb, nieto de al-'Ādil, conocido por la campaña contra el reino de Jerusalén que provocó la Séptima Cruzada ${ }^{47}$. El ya mencionado Donald Sidney Richards investigó la muerte del mismo príncipe, publicando su trabajo en $2000^{48}$. Es también autor de un capítulo dedicado a los principales miembros de la dinastía incluido en una obra colectiva sobre la Jerusalén de la época ${ }^{49}$. También trabajó en este tema Joseph Drory

${ }^{42}$ Youssif, E., Saladin et l'epopée des Ayyoubides: chroniques syriaques, París, L’Harmattan, 2010.

${ }^{43}$ Ehrenkreutz, A., Saladin, Albany, State University of New York Press, 1972.

${ }^{44}$ MaYer, H.E., "Saladin by Andrew Ehrenkreutz", Reseña, Speculum, 49/4 (1974), pp. 724-727.

${ }^{45}$ EddÉ, A.M., Saladin, París, Flammarion, 2008.

${ }^{46}$ Dahlmanns, F.J., Al-Malik al-'Adil: Ägypten und der Vordere orient in den Jahren 589/1193 bis 615/1218: ein Beitrag zur ayubidischen Geschichte, Tesis Doctoral, Universität Giessen, 1975.

${ }^{47}$ CAHEN, C., "Le testament d'al-Malik as-Salih Ayyub, mélanges offerts a H. Laoust", BEO, 29 (1977), pp. 97-114.

${ }^{48}$ Richards, D.s., "More on the Death of the Ayyubid Sultan al-Salih Najm al-Din Ayyub", en BAHM-HARDING, Ç. e IMBER, C. (eds.), The Balance of Truth: Essays in Honour of Professor Geoffrey Lewis, Estambul, The Isis Press, 2000, pp. 269-274.

${ }^{49}$ Richards, D.s., "Biographies of Ayyubid Sultans", en Hillenbrand, R. y Auld, S. (eds.), Ayyubid Jerusalem: The Holy City in Context 1187-1250, Londres, Altajir Trust, 2009, pp. 441-455. 
(1945), profesor de la Universidad de Bar Han. Especialista en historia política de Siria y Egipto en la Edad Media, y autor de varios artículos sobre Jerusalén medieval, ha publicado en 2003 un estudio sobre al-Nāṣir Dāwūd de Damasco ${ }^{50}$.

Son reseñables las investigaciones recientes sobre dos mujeres que tuvieron un protagonismo notable en la historia ayubí: Dayfa Jātūn y Šaŷar al-Durr. La primera era una de las hijas de al-'Âdil, casada con al-Z̄āhir Gāzī, gobernante de Alepo. Tras la muerte de su esposo, ejerció la regencia durante la minoría de su nieto al-Nāṣir Yūsuf (634 H./1236-640 H./1242) $)^{51}$. En cuanto a Šaŷar al-Durr, fue la viuda del último sultán ayubí de Egipto, al-Șālih Ayyūb, muerto en Mansurah durante la Séptima Cruzada. Šaŷar tomó el título de sultana, con el mameluco 'Izz al-Dīn Aybeg como atabeg, hecho que desencadenó la guerra con los príncipes de Siria, finalizada por mediación del califa de Bagdad. Posteriormente, contrajo matrimonio con 'Izz alDīn, pero ambos fueron asesinados cuando los mamelucos tomaron el poder definitivamente en Egipto en $1250^{52}$.

\section{Aspectos políticos, administración y gobierno}

No existen demasiados estudios sobre estos temas, tal vez por el predominio ejercido por los historiadores que trabajan sobre la historia social, económica o de las mentalidades. En 1977, Richard Stephen Humphreys (1942), profesor de Historia de la Universidad de California y uno de los mayores expertos mundiales en la historia de los mamelucos, publicó una magnífica monografía sobre los ayubíes de Damasco, basada en su tesis doctoral, que tuvo una excelente acogida en círculos académicos ${ }^{53}$. Peter Holt destacó en una reseña la necesidad de una obra como ésta, que, pese a centrarse en la capital, ofrece una visión global de la situación en Siria y Egipto, de las relaciones no siempre pacíficas entre los príncipes, sus alianzas, de la organización política y militar de sus estados y de su contexto histórico ${ }^{54}$. En Europa cabe citar las obras de Peter Malcolm Holt (1918-2006), catedrático de Historia del Próximo Oriente en la Universidad de Londres. Inicialmente se interesó por Sudán y Egipto en la Edad Moderna, aunque en sus últimos años se especializó en la Edad Media. Colaboró activamente con Jonathan Riley-Smith en el estudio de las Cruzadas, organizando seminarios como el celebrado en la Escuela de Estudios Orientales y Africanos de

${ }^{50}$ Drory, J., “Al-Nasir Dawud: A Much Frustrated Ayyubid Prince”, AM, 15/2 (2003), pp. 161-187.

${ }^{51}$ El-Azhari, T.K., "Dayfa Khatun, Ayyubid Queen of Aleppo (1236-1242)", Annals of Japan Association for Middle East Studies, 15 (2000), pp. 27-55; y TABBAA, Y., "Dayfa Khatun: Regent Queen and Architectural Patron", en Ruggles, D.f. (ed.), Women, Patronage and Self-Representation, Nueva York, State University of New York Press, 2000, pp. 17-34.

52 Sobre algunos aspectos de la vida de Šaŷar al-Durr, véase SoEtens, S., "Sagarat al-Durr: A Comparative Study of Three Historical Sources", Orientalia Lovaniensia Periodica, 30 (1999), pp. 97-112; DuncAN, D.L., "Scholary Views of Shajarat al-Durr: A Need of Consensus", Arab Studies Quarterly, 22/1 (2000), pp. 51-69; y Levanoni, A., "Sagar al-Durr, a Case of Female Sultanate in Medieval Islam", en ES III, pp. 194-209; y ThORAU, P., "Shadschar ad-Durr, Sultanin von Ägypten", en Wieczorek, A., Fansa, M. y Meller, H. (eds.), en Saladin und die Kreuzfahrer, Maguncia, Verlag Philipp von Zabern, 2005, pp. 167-170.

${ }^{53}$ Humphreys, R.S., The Ayyubids of Damascus, 589-658/1193-1260: a Principality in Medieval Syria, Tesis Doctoral, dir. Andrew Ehrenkreutz, University of Michigan, 1969; pub. From Saladin to the Mongols, the Ayyubids of Damascus, 1193-1260, Albany, University of New York Press, 1977.

${ }^{54}$ Holt, P.M., "From Saladin to the Mongols, the Ayyubids of Damascus, 1193-1260 by R. Stephen Humphreys", BSOAS, 41/3 (1978), pp. 592-595. 
Londres en 1975, cuyas actas se publicaron en $1978^{55}$. Unos años más tarde escribió una monografía sobre las Cruzadas en la que dedicó un capítulo a las instituciones políticas ayubíes ${ }^{56}$.

Encontramos algunos especialistas en Oriente Próximo, como el profesor de la Universidad de Qatar, Taef Kamel el-Azhari (1963), experto en la Siria medieval, que ha investigado la influencia de los diversos grupos de poder en los principados ayubíes $^{57}$; también Mohamed Hawari (1950), profesor de la Universidad Ain Shams de El Cairo, especialista en religión judía que estudió las relaciones judeo-musulmanas en época medieval ${ }^{58}$. Eli Alshech, doctor en Estudios Islámicos por Princeton, experto en leyes islámicas y asesor del gobierno norteamericano en asuntos de terrorismo global y yiha $\bar{d}$, publicó un trabajo sobre la exención del pago de la ŷizyah a los pobres durante el periodo que tratamos ${ }^{59}$. Entre los historiadores israelíes, el ya mencionado David Ayalon publicó en 1998 una monografía en la que se analiza la influencia de los eunucos sobre los dirigentes ${ }^{60}$. Debemos destacar a Yaacov Lev, profesor de la universidad Bar Ilan. Su línea de investigación es la historia social, económica y militar del Próximo Oriente medieval, especialmente la de Siria y Egipto de los siglos IXXII. Participó en uno de los congresos de la universidad de Lovaina con una ponencia sobre la emergencia de la élite ayubí en Egipto publicada en $2007^{61}$.

La contribución alemana corresponde en primer lugar a Hannes Möhring (1949), profesor de Historia Medieval en la Universidad de Bayreuth. Su tesis doctoral abordó la diplomacia de Saladino durante la Tercera Cruzada ${ }^{62}$. Es, además, autor de la primera biografía en alemán del sultán dirigida al gran público ${ }^{63}$. Stefan Heidemann (1961), profesor de Estudios Islámicos en la Universidad de Hamburgo, ha centrado sus investigaciones en los periodos de transición y cambio en las sociedades islámicas de los siglos XII y XIII. También se interesa por la numismática musulmana. Publicó un estudio de un decreto de al-'Ādil en el que el sultán confirmaba otros anteriores de Saladino, aunque la mayor parte de este trabajo es un análisis diplomático del texto ${ }^{64}$. Konrad Hirschler, que imparte clase actualmente en la Universidad de Londres, es experto en historiografía islámica, especialmente en la del tiempo de las Cruzadas, e investiga grupos minoritarios y extranjeros en el Próximo Oriente medieval. En

${ }^{55}$ Holt, P.M., Eastern Mediterranean Lands in the Period of Crusades, Oxford, Aris \& Phillips Imprint, 1978

${ }^{56}$ Holt, P.M., "Institutions from the Seljukids to the Ayyubids" en HOLT, P.M., The Age of Crusades: The Near East from the Eleventh Century to 1517, Londres, Longman, 1986, pp. 67-81.

${ }^{57}$ El-Azhari, T.K., "The Office of atabeg in Syria under the Nurids and the Ayyubids", AM, 11 (1999), pp. 47-66; y "The Influence of Eunuchs in the Ayyubid Kingdom", en ES IV, pp. 127-142.

${ }^{58}$ Hawari, M., "Muslim-Jewish Relations in Ayyubid Egypt, 1171-1250", en MA'OZ, M. (ed.), The Meeting of Civilizations: Muslims, Christians and Jewish, Brighton, Sussex Academic Press, 2009, pp. 66-74.

${ }_{59}$ Alsech, E., "Islamic Law, Practice and Legal Doctrine: Exempting the Poor from the Jizya under the Ayyubids (1171-1250), Islamic Law and Society, 10/3 (2003), pp. 348-375.

${ }^{60}$ Ayalon, D., Eunuchs, Caliphs and Sultans: A Study in Power Relationships, Jerusalén, Magnes Press, 1998.

${ }^{61}$ LEV, Y., "The Dismemberment of the Fatimid State and the Emergence of the New Ayyubid Elite in Egypt”, en ES V, pp. 129-152.

${ }^{62}$ MöHring, H., Sultan Saladin und der Dritte Kreuzzug: Aiyubidische Strategie und Diplomatie in Vergleich vornehmlich der arabisches mit laleinischen Quellen, Tesis Doctoral, Universität Frankfurt am Main, 1977.

${ }^{63}$ Möhring, H., Saladin: Der Sultan und seine Zeit, 1138-1193, Munich, C.H. Beck, 2005.

${ }^{64}$ Heidemann, S., 'Un décret d'al-Malik al-’Adil relatif aux moines du Mont Sinaï’, AI, 31 (1997), pp. 81-107. 
2007 publicó un trabajo sobre la legislación ayubí relativa a la minoría de los jóvenes príncipes $^{65}$. Recientemente se ha publicado la traducción al inglés de un estudio de Michael Köhler (1958) sobre las relaciones diplomáticas entre francos y musulmanes en Tierra Santa durante los siglos XI al XIII. Uno de los capítulos está dedicado a los tratados y alianzas realizados en época de Nūr al-Dīn y Saladino, y otro a la diplomacia de sus sucesores ${ }^{66}$. Esta misma cuestión es abordada por Jay Harris Nierman en su tesis doctoral, leída en 1971, y un estudio publicado unos años después ${ }^{67}$. La política de los ayubíes respecto a sus enemigos cristianos ha sido estudiada también por Laila Atrache en su tesis, publicada en $1996^{68}$.

También contamos con trabajos sobre los cancilleres y su labor, la tesis de Ibrahim Hafsi versa sobre la corresponencia de al-Fāḍil, jefe de la cancillería de Saladino ${ }^{69}$. Actualmente, están en preparación un estudio sobre su documentación por parte de especialistas del Orient Institut de Beirut ${ }^{70}$ y una tesis doctoral dirigida por JeanMichel Mouton ${ }^{71}$.

No hemos encontrado demasiados trabajos sobre política económica y la mayoría corresponden a autores ya mencionados. Claude Cahen publicó en 1977 un estudio sobre las finanzas del Egipto medieval ${ }^{72}$ y, unos años después, un artículo sobre la reforma monetaria llevada a cabo por al-Kāmil ${ }^{73}$. Yaacov Lev expuso una ponencia en el congreso de Lovaina de 2007 sobre la economía egipcia en época ayubí ${ }^{74}$, mien-

${ }^{65}$ Hirschler, K., "He is a Child and this Land is a Borderland of Islam: Under-age Rule and the Quest for Political Stability in the Ayyubid Period”, AM, 19/1 (2007), pp. 29-46.

${ }^{66}$ KöHLER, M., "Frankish-Muslim Relations in the Period of Nur al-Din and Saladin (1158-1192)" en KÖHLER, M., Allianzen und Verträge zwischen fränkischen und islamischen Herrschern in Vorderen Orient, Berlín, De Gruyter, 1991, trad. inglesa Alliances and Treaties between Frankish and Muslim Rulers in the Middle East. Cross-Cultural Diplomacy in the Period of the Crusades, Leiden, Brill, 2013, pp. 175-275; e "Instruments and Implications of Frankish-Muslim Relations in the Middle East during the Twelfth and Thirteenth Centuries", ibidem, pp. 277-319.

${ }^{67}$ Nierman, J.H., Aimery II of Jerusalem and His Relations with His Ayyubid Neighbors, Tesis Doctoral, New York University, 1971; y "Levantine Peace following the Third Crusade: A New Dimension in Frankish-Muslim Relations", The Muslim World, 65/2 (1975), pp. 107-118.

${ }^{68}$ Atrache, L., Die Politik der Ayyūbiden: die fränkisch-islamischen Beziehungen in der ersten Hälfte des 7./13. Jahrhunderts unter besonderer Berücksichtigung des Feindbildes, Tesis Doctoral, Universität Göttingen, 1994, pub. Münster, Rhema, 1996.

${ }^{69}$ Hafsi, I., Correspondence officielle et privée d'al-Qadi al-Fadil, Tesis Doctoral, dir. Mohammed Arkoun, Université Sorbonne-Paris IV, 1979.

${ }^{70}$ Leder, S., Dorpmueller, S. y Helmy, M., Chancery and Diplomatics Exemplified by the Correspondence of al-Qadi al-Fadil, Orient Institut Beirut, en preparación: http://www.orient-institut.org/index.php?id=93.

${ }^{71}$ Haddad, K., Les lettres de chancellerie du Qadi al-Fadil (529/1134-597/1199), secrétaire de Saladin, Tesis Doctoral, dir. Jean-Michel Mouton, École Pratique des Hautes Études, en preparación.

${ }^{72}$ CAHEN, C., Makhzūmiyyāt. Études sur l'histoire économique et financière de l'Égypte médiévale, Leiden, E.J. Brill, 1977.

${ }^{73}$ CAhen, C., "Monetary Circulation in Egypt at the Time of Crusades and the Reform of al-Kamil", en Udovitch, A. (ed.), The Islamic Middle East, 700-1900: Studies in Economic and Social History, Princeton, Darwin Press, 1981, pp. 315-333.

${ }^{74}$ Lev, Y., "Saladin's Economic Policies and the Economy in the Ayyubid Egypt", en ES V, pp. 307-348. 
tras que Heidemann participó en una obra colectiva sobre Jerusalén (2009) con un capítulo sobre el crecimiento económico en Palestina ${ }^{75}$.

\section{Historias locales}

A mediados de los años 70, Michael Lawrence Bates (1941) se doctoró con una tesis sobre la conquista de Yemen por los ayubíes ${ }^{76}$, aunque dedicó sus investigaciones posteriores a la numismática, siendo en la actualidad conservador emérito de monedas islámicas de la American Numismatic Society. El ya mencionado Richard Stephen Humphreys realizó un estudio sobre Alepo y Damasco en época medieval, aparecido en $1998^{77}$.

Entre los historiadores franceses, Jean-Michel Mouton (1963) publicó en 2001 un trabajo sobre el Sinaí que incluye un apartado sobre las relaciones entre Saladino y los beduinos locales ${ }^{78}$. Guy Ducatez, especialista en técnicas de navegación en el Indico durante la Edad Media y los geógrafos árabes de la época, escribió en 2004 un artículo para Annales Islamologiques sobre Adén en los siglos XII y XIII ${ }^{79}$.

Hay que señalar también la historia de Damasco de Ross Burns, doctor por la Universidad de Sidney y diplomático que vivió muchos años en el Próximo Oriente. Fue publicada en 2005, e incluye capítulo dedicado a la dinastía ${ }^{80}$. Finalmente, debemos mencionar la ya citada obra colectiva Ayyubid Jerusalem: The Holy City in Context $(2009)^{81}$. En ella podemos encontrar referencias a distintos aspectos de la Ciudad Santa en el periodo que nos ocupa (culturales, religiosos, económicos, etc.) a cargo de algunos de los más reputados especialistas. Actualmente se encuentra en preparación una historia de la ciudad de Ramla, en la que Donald Sidney Richards es responsable del capítulo correspondiente a la época ayubíi ${ }^{82}$.

${ }^{75}$ Heidemann, S., "Economic Growth and Currency in Ayyubid Palestine", en Hillenbrand, R. y. Auld, S. (eds.), Ayyubid Jerusalem: The Holy City in Context, 1187-1250, Londres, Altajir Trust, 2009, pp. $276-300$.

${ }^{76}$ Bates, M.L., Yemen and its Conquest by the Ayyubids of Egypt (AD 1137-1202), Tesis Doctoral, University of Chicago, 1975.

${ }^{77}$ Humphreys, R.s., Towards a History of Aleppo and Damascus in the Early Middle Ages (635-1260) Tokio, University of Tokyo, 1998.

${ }^{78}$ Mouton, J.M., "Saladin et les bédouins du Sinaï”, Cahiers des Annales Islamologiques, 21 (2001), pp. 197-206.

${ }^{79}$ Ducatez, G., "Aden aux XII ${ }^{\mathrm{e}}$ et XIII' siècles selon Ibn al-Mugawir: son passé légendaire, son histoire sour les Zuray’ïdes et les Ayyoubides, son site, ses monuments et ses aménagements”, AI, 38 (2004), pp. 158200.

${ }^{80}$ Burns, R., "Saladin and the Ayyubids", en BURNS, R., Damascus: A History, Londres, Routledge, 2005, pp. 170-194.

${ }^{81}$ Hillenbrand, R. y AULD, S. (eds.), Ayyubid Jerusalem: The Holy City in Context, 1187-1250, Londres, Altajir Trust, 2009.

${ }^{82}$ Richards, D.s., "Ramla in the Ayyubid and Mamluk Periods", en Pringle, D. y Petersen, A. (eds.), Ramla: A City of Muslim Palestine, AD.c. 715/1917: Studies in History, Architecture and Archaeology, Oxford, British Academy Monographs in Archaeology, en preparación. 


\section{Guerra y organización militar}

\section{Fortalezas}

Este campo es uno de los más estudiados gracias a la contribución de arqueólogos especializados en fortificaciones medievales del Próximo Oriente que trabajan, en su mayoría, sobre el propio terreno. En este sentido, ha sido fundamental la contribución del Institut Français du Proche-Orient (IFPO) de Damasco, que ha desarrollado misiones en varios enclaves sirios, como Sahyūn, Marqab, Salkhad, Masyāf o la propia ciudadela de la capital. En ellas han participado dos especialistas franceses que han publicado sus experiencias en fechas recientes: Benjamin Michaudel y Cyril Yovitchitch.

Benjamin Michaudel (1975) es doctor en Arqueología con la tesis Les fortifications ayyoubides et mameloukes en Syrie côtière de la fin du XII au début du XIVe siècle $(2005)^{83}$. Tras doctorarse, se traslada a Siria, donde participa en numerosas excavaciones y llega a ser director entre 2007 y 2010 de la misión sirio-francesa para el estudio del castillo de Sahyūn (Saône). Como miembro del IFPO ha desarrollado un inventario de los lugares fortificados sirios y una investigación sobre la guerra y la paz en el Próximo Oriente medieval (ss. X-XV). Fruto de estos trabajos son numerosos estudios sobre arquitectura militar y técnicas de asedio en la época de los ayubíes y los primeros mamelucos ${ }^{84}$.

Cyril Yovitchitch se doctora también en Arqueología con otra tesis sobre las fortificaciones ayubíes ${ }^{85}$. Su labor investigadora en el IFPO se enfoca hacia las características de la arquitectura militar islámica, las técnicas de construcción y la relación entre las formas arquitectónicas y la expresión del poder. Ha participado en el estudio arqueológico de la fortaleza de Salkhad y ha colaborado con Michaudel en el inventario mencionado anteriormente. Es autor de numerosas publicaciones y ponencias sobre la época que nos ocupa ${ }^{86}$.

${ }^{83}$ Michaudel, B., Les fortifications ayyoubides et mameloukes en Syrie côtière de la fin du XII au début du XIV siècle, Tesis Doctoral, dir. Marianne Barrucand, Université Sorbonne-Paris IV, 2005.

${ }^{84}$ Michaudel, B., "Le château de Saône (Sayün-Qal'at Salah al-Din) et ses défenses", Architecture Islamique, 11 (2001), pp. 201-206; "Étude historique de Qal'at Salah al-Din (Sayün-Château de Saône)", [http:// castellorient.fr] [en línea] (2002) (consulta:10/10/2013); "Les refortifications ayyoubides et mameloukes en Syrie du Nord (fin XII e-début XIVe siècles), en Faucherre, N., Mesqui, J. y Prouteau, N. (eds.), La fortification au temps des Croisades. Actes du Colloque International de Phartenay. (2002), Rennes, Presses Universitaires de Rennes, 2004, pp. 179-189; "The Development of Islamic Military Architecture during the Ayyubid and Mamluk Reconquest of Frankish Syria", en Kennedy, H. (ed.), Muslim Military Architecture in Greater Syria, Leiden, Brill, 2006, pp. 106-121; "The Use of Fortification as a Political Instrument by the Ayyubids and the Mamluks in Bilad al-Sham and in Egypt (Twelfth-Thirtheenth Centuries)", MSR, 11/1 (2007), pp. 55-67; y "La poliorcétique au temps de Saladin, l'exemple de la campagne militaire de 1188 en Syrie côtiére", $A I, 43$ (2009), pp. 245-272.

${ }^{85}$ Yovitchiтch, C., Forteresses ayyoubides de la principauté de Damas: contribution à l'histoire des fortifications médiévales proche-orientales en terre d'Islam, Tesis Doctoral, dir. Marianne Barrucand, Université Sorbonne-Paris IV, 2007; pub. Forteresses du Proche-Orient, l'architecture militaire des Ayyoubides, París, Presses de 1'Université Paris-Sorbonne, 2011.

${ }^{86}$ Yovitchiтch, C., "An Early Ayyubid Fortification in the North of Jordan: 'Aljun Castle”, International Conference on Islamic Fortification in Bilad al-Sham (Alepo,16/19 de septiembre de 2003), inédito; "Les fortifications ayyoubides et mameloukes sur la route du Damas au Caire", Communication pour le Centre d'Étude d'Histoire de la Défense (Château de Vincennes, París, 13 de marzo de 2004), inédito; "The Tower of 
Otro especialista importante es el ya citado Jean-Michel Mouton, director de estudios de Historia y Arqueología del mundo musulmán en la École Pratique des Hautes Études de París. Elabora su tesis doctoral sobre una época anterior a la ayubíi ${ }^{87}$, investigando después sobre el sistema de fortificación, el análisis del suministro de agua y la función religiosa de la fortaleza de Sadr, construida por Saladino en el Sinaí a finales del siglo XII ${ }^{88}$. Entre 2010 y 2012 ha trabajado en la historia, arquitectura y epigrafía de las puertas de Damasco ${ }^{89}$, colaborando también con otros expertos en este mismo campo $^{90}$.

Entre los autores de habla inglesa podemos destacar a Marcus Milwright, profesor escocés de Arte y Arquitectura islámicos en la Universidad de Victoria (Canadá), que ha trabajado en la fortaleza de Kerak y publicado una monografía sobre su historia ${ }^{91}$. También citaremos a Denys Pringle (1950), docente en la Universidad de Cardiff y especialista en fortalezas del mundo mediterráneo desde el periodo bizantino a los primeros años de la Edad Moderna. Participó en uno de los congresos de Lovaina con una ponencia sobre el castillo de Ayla ${ }^{92}$.

La israelí Sarah Kate Raphael, doctora en Arqueología islámica por la Universidad Hebrea de Jerusalén con una tesis sobre el concepto de defensa musulmán en época ayubí ${ }^{93}$, es autora de estudios sobre temas militares del Próximo Oriente medieval. Ha participado en numerosas excavaciones en zonas fortificadas de Israel. En su mo-

Aybak in 'Ajlun Castle: An Exemple of the Spread of an Architectural Concept in Early $13^{\text {th }}$ Century Ayyubid Fortification", en Kennedy, H. (dir.), Muslim Military Architecture in Greater Syria, Leiden, Brill, 2006, pp. 225-242; "La tour maîtresse dans la sphére ayyoubide: mirage ou réalité ?", Intervention pour le Conseil International des Monuments et de Sites, rencontre "Un patrimoine méditerranéen partagé: forteresses de l'époque des croisades" (Aigues Mortes, 26/27 de enero de 2007), inédito; "Die Befestigung der Tore aiyubidischer Burgen-Herausbildung eines Standards", en Piana, M. (ed.), Burgen und Städte der Kreuzzugszeit, Petersberg, Michael Imhof Verlag, 2008, pp. 110-117; "Die aiyubidische Burg "Ajlun”, ibídem, pp. 118-125; "Architecture militaire et représentaton du pouvoir dans la Syrie ayyoubide (XIII siècle)", $17^{\text {th }}$ Colloquium on the History of Egypt and Syria in the Fatimid, Ayyubid and Mamluk Eras (Gante, 14/16 de mayo de 2008), inédito; "Qal'at Najm and the Ayyubid Fortifications", Conférence pour l'Institut Français d'Études Annatoliennes dans le cycle "Fortifier un lieu, une ville, un territoire entre le $X^{e}$ et le $X V^{e}$ siècles: exemples anatoliens et des villes voisines", (Estambul, mayo de 2009), inédito; "Hammams et fortifications: quelques remarques sur trois bains des périodes ayyoubide et mamelouke", Actes du colloque "Balaneia, thermes et hammams, 25 siècles de bain collectif (Proche-Orient, Egypte et Peninsule Arabique)", (Damasco, 2/6 de noviembre de 2009), inédito; y "Les tours maîtresses ayyoubides", Histoire et images médiévales, 20 (2010), pp. 26-33.

${ }^{87}$ Mouton, J.M., Damas et sa principauté sous les Saljoukides et les Bourides (468-549/1076-1154), Tesis Doctoral, dir. Dominique Sourdel, Université Sorbonne-Paris IV, 1993.

${ }^{88}$ Mouton, J.M., Sadr, une forteresse de Saladin au Sinaï. Histoire et Archéologie, París, De Boccard, 2010.

${ }^{89}$ Mouton, J.M., "Damas. Portes et mourailles millénaires", Archéologia, 473 (2010), pp. 38-50.

${ }^{90}$ Mouton, J.M.; Sourdel, D.; Sourdel-Thomine, J. y Dayoub, B.,"Témoignages épigraphiques damascains sur un sayh méconnu d'époque ayyoubide”, Der Islam, 87/1 (2012), pp. 185-203.

${ }^{91}$ MiLwright, M., The Fortress of the Raven: Karak in the Middle Islamic Period (1100-1650), Leiden, Brill, 2008.

${ }^{92}$ Pringle, D., "The Castles of Ayla (al-'Aqaba) in the Crusader, Ayyubid and Mamluk Period", en ES IV, pp. 333-354.

${ }^{93}$ Raphael, S.K., The Muslim Concept of Defense in Greater Syria in the Late $12^{\text {th }}$ and $13^{\text {th }}$ Centuries in the Light of Historical, Archaeological and Architectural Analysis of Ayyubid and Early Mamluk Fortifications, Tesis Doctoral, dirs. Reuven Amitai y Ronnie Ellenblum, The Hebrew University of Jerusalem, 2008. 
nografia Muslim Fortresses in the Levant, Between Crusaders and Mongols (2010) dedica un capítulo a las fortalezas ayubíes ${ }^{94}$.

La fortaleza de Shawak ha sido estudiada por Michele Nucciotti (1972), profesor de Arqueología en la Universidad de Florencia, que ha publicado varios trabajos en los últimos años ${ }^{95}$. Por su parte, Yasser Tabbaa, profesor en diversas universidades norteamericanas, es autor de estudios sobre las fortificaciones ayubíes en Jerusalén y Alepo ${ }^{96}$

\section{Ejércitos y técnicas militares}

Jean Richard (1921), célebre medievalista francés, miembro de la Académie des Inscriptions et Belles-Lettres desde 1987 y especialista en historia del Oriente Latino, publicó en 1952 un estudio sobre los mercenarios francos en los ejércitos musulmanes $^{97}$. En esta década comenzó a publicar también David Ayalon (1914-1998), bien conocido por sus estudios sobre la esclavitud militar en el Islam medieval y la historia del Sultanato Mameluco. Es autor de algunos artículos sobre la presencia de estos esclavos en el ejército, su progresivo aumento e influencia durante el periodo ayubí y la forma en la que los mamelucos conservaron buena parte de la organización militar de sus predecesores ${ }^{98}$. También Richard Stephen Humphreys analizó esta cuestión en dos extensos artículos aparecidos en $1977^{99}$.

Los discípulos de Cahen trabajaron igualmente en los aspectos militares del periodo ayubí. Anne-Marie Eddé, como especialista en el principado de Alepo, estudió los asedios que sufrió la ciudad en la época. Sobre estos últimos expuso una ponencia en el $18^{\circ}$ Congreso de la Sociedad de Historiadores Medievalistas celebrado en

${ }^{94}$ RaPHAel, S.K., "Ayyubid Fortresses in the Late Twelfth and Early Thirteenth Centuries", en RaPhaEL, S.K., Muslim Fortresses in the Levant, Between Crusaders and Mongols, Londres, Routledge, 2010, pp. 4-51.

${ }^{95}$ Nucсіотті, M., "Analisi stratigrafiche degli elevati a Shawbak: primi risultati”, en VANNINI, G. (ed.), Archeologia dell'insediamento crociato-ayyubide in Transgiordania: il Progetto Shawbak, Florencia, Edizioni All'Insegna del Giglio, 2007, pp. 29-57; "Shawbak and South Transjordan in the Ayyubid Epoch", en VANNINI, G. y Nucciotтi, M. (eds.), From Petra to Shawbak, Archeology of a Frontier, Florencia, Giunti Editore, 2009, pp. 110-125; e "Il palazzo Ayyubide di Shawak, analisi archeologica e contestualizzazione storica", en Changes and Challenges - 11th International Conference on the History and Archeology of Jordan, París, 7-14 de junio 2010, inédito.

${ }^{96}$ TABBAA, Y., "Defending Ayyubid Aleppo: The Fortifications of al-Zahir Ghazi (1186-1216)", en KeNNEDy, H. (dir.), Muslim Military Architecture in Greater Syria, Leiden, Brill, 2006, pp. 176-183; y "An Image of What Once Was: The Ayyubid Fortifications of Jerusalem", en Hillenbrand, R. y Auld, S. (eds.), Ayyubid Jerusalem: The Holy City in Context, 1187-1250, Londres, Altajir Trust, 2009, pp. 460-468.

${ }^{97}$ Richard, J., "An Account of the Battle of Hattin Referring to the Frankish Mercenaries in Oriental Muslem States", Speculum, 27/2 (1952), pp. 168-177.

${ }^{98}$ Ayalon, D., "Studies on the Structure of the Mamluk Army I", BSOAS, 15/2 (1953), pp. 203-228; "Studies on the Structure of the Mamluk Army II", BSOAS, 15/3 (1953), pp. 448-476; "Studies on the Structure of the Mamluk Army III", BSOAS, 16/1 (1954), pp. 57-90; y "Aspects of the Mamluk Phenomenon, Ayyubids, Kurds and Turcs", Der Islam, 54 (1977), pp. 1-32.

${ }^{99}$ HumphreYs, R.S., "The Emergence of the Mamluk Army”, Studia Islamica, 45 (1977), pp. 67-99; y “The Emergence of the Mamluk Army (Conclusion)”, Studia Islamica, 46 (1977), pp. 147-182. 
Montpellier en $1987^{100}$. Posteriormente, investigó la composición de los ejércitos, sus unidades y rangos ${ }^{101}$.

A finales de los años 80 comenzaron a aparecer trabajos de nuevos especialistas. Se celebraron congresos en Israel sobre los estados cruzados en los que se trató la historia musulmana. Un ejemplo es el celebrado en Haifa y Jerusalén entre el 2 y el 6 de julio de 1987, coincidiendo con el ochocientos aniversario de la gran batalla de Hattin, cuyas ponencias fueron publicadas en $1992^{102}$. Entre los participantes podemos destacar a Benjamin Z. Kedar (1938), profesor de la Universidad Hebrea de Jerusalén y presidente entre 1995 y 2002 de la Society for the Study of the Crusades and the Latin East (SSCLE). Una de sus líneas de investigación se centra en las actividades culturales de los establecimientos latinos de Levante, comparándolas con el desarrollo de los países europeos de origen y el entorno islámico ${ }^{103}$. También ha estudiado el sitio de Acre por parte de Saladino ${ }^{104}$. Otro de los ponentes, William J. Hamblin (1952), profesor de la Brigham Young University (Utah) y analista de Oriente Medio del Departamento de Defensa norteamericano, participó con un estudio de la influencia de algunos tratados de estrategia en la técnica militar de Saladino ${ }^{105}$.

El ya citado Yacov Lev, miembro del Departamento de Estudios del Próximo Oriente de la Universidad Bar Ilan de Ramat Gant, trabaja actualmente en un proyecto de la Universidad de Lovaina denominado Qadis, Courts and Society in Medieval Egypt, $7^{\text {th }}-13^{\text {th }}$ Centuries. Es especialista en el Egipto fatimí y de los primeros ayubíes, así como autor de una obra en la que se tratan los primeros años del gobierno de Saladino ${ }^{106}$. Ha publicado estudios sobre el tratamiento dispensado a los prisioneros de guerra y aspectos militares islámicos en la época de las Cruzadas ${ }^{107}$. También ha estudiado este tema Yvonne Friedman, profesora de la Universidad Bar-Ilan y especialista en las relaciones entre cristianos y musulmanes en Tierra Santa. Es autora

${ }^{100}$ EdDÉ. A.M., "Sous les mourailles d'Alep: assaillants et défenseurs de 351/962 à 658/1260”, en Le combattant au Moyen Age, Actes du XVIII Congrés de la Societé des Historiens Médiévistes de l'Enseignement Supérieur Public (Montpellier, 1987), Nantes, CDI Editions, 1991, pp. 63-75.

${ }^{101}$ EdDÉ, A.M., "Quelques institutions militaires ayyoubides”, en ES I, pp. 163-174; y "Kurdes et Turcs dans l'armée ayyoubide de Syrie du Nord", en LEV, Y. (ed.), War and Society in the Eastern Mediterranean, $7^{\text {th }}-15^{\text {th }}$ Centuries, Leiden, Brill, 1997, pp. 225-236.

${ }^{102}$ Kedar, B.Z. (ed.), The Horns of Hattin: Proceedings of the $2^{\text {nd }}$ Conference of the Society for the Study of Crusades and the Latin East, (Jerusalem and Haifa, 2/6 July 1987), Jerusalén, Yad Izhak Ben-Zvi, 1992.

${ }^{103}$ Kedar, B.Z., Crusade and Mission: European Approaches toward the Muslims, Princeton, Princeton University Press, 1988.

${ }^{104}$ Kedar, B.Z., “A Western Survey of Saladin's Forces at the Siege of Acre”, en KedAr, B.Z., RILEY-SMITH, J. e Hiestand, R. (eds.), Montjoie. Studies in Crusade History in Honour of Hans Eberhard Mayer, Aldershot, Ashgate Publishing Ltd., 1997, pp. 113-122.

${ }^{105}$ Hamblin, W.J., "Saladin and Muslim Military Theory", en Kedar, B. (ed.), The Horns of Hattin: Proceedings of the $2^{\text {nd }}$ Conference of the Society for the Study of Crusades and the Latin East, (Jerusalem and Haifa, 2/6 July 1987), Jerusalén, Yad Izhak Ben-Zvi, 1992, pp. 228-238.

${ }^{106}$ Lev, Y., Saladin in Egypt, Leyden, Brill, 1998.

${ }^{107}$ LeV, Y., "Prisoners of War during the Fatimid-Ayyubid Wars with the Crusaders", en GERVERS, M. y Powell, J.M. (eds.), Tolerance and Intolerance: Social Conflict in the Age of Crusades, Nueva York, Syracuse University Press, 2001, pp. 11-27; e "Infantry in Muslim Armies during the Crusades", en PRYOR, J. (ed.), Logistics of Warfare in the Age of the Crusades: Proceedings of a Workshop held at the Centre for Medieval Studies (University of Sydney, 30 September to 4 October 2002), Aldershot, Ashgate, 2006, pp. 185-208. 
de varios trabajos sobre los cautivos y las formas de rescate ${ }^{108}$. Otro estudioso de la problemática de los prisioneros de guerra y el trato que recibían en tiempos de Saladino es Giuseppe Ligato (1959), miembro de la Society for the Study of the Crusades and the Latin East, del que contamos con dos trabajos publicados en 2000 y $2005^{109}$.

Los especialistas ingleses y norteamericanos han publicado asimismo trabajos sobre temas militares. Destaca el historiador David Nicolle (1944), que se interesó en un principio por Bizancio y la historia turca medieval. Después de viajar durante unos años por el Próximo Oriente debido a su trabajo en la BBC, comenzó a estudiar el mundo islámico de los siglos XII al XIV, doctorándose en Edimburgo en 1983 con la tesis The Military Technology of Classical Islam ${ }^{110}$. Es uno de los más reconocidos especialistas en armamento e historia militar del mundo musulmán medieval y autor de numerosas obras científicas ${ }^{111}$ y divulgativas ${ }^{112}$.

Sobre la conquista del Norte de África por parte de Saladino, menos estudiada que el resto de expediciones, contamos con algunos trabajos, como el de Jean-Michel Mouton, en el que presenta la posibilidad de que esta empresa fuera una iniciativa personal del emir Qarāqū šs ${ }^{113}$. Amar Baadj publica en 2013 un artículo sobre las cam-

${ }^{108}$ Friedman, Y., "Women in Captivity and their Ransom in the Crusader Period", en Goodich, M., Menasche, S. y Schein, S. (eds.), Cross Cultural Convergences in the Crusader Period, Nueva York, Peter Lang, 1995, pp. 75-87; “The Ransom of Captives in the Latin Kingdom of Jerusalem”, en Balard, M.(ed.), Autour de la Première Croisade, Paris, Publications de la Sorbonne, 1996, pp. 177-189; "Captivity and Ransom-The Experience of Women", en LAmbert, S. y Edgington, S. (eds.), Gendering the Crusades, Cardiff: University of Wales Press, 2001, pp. 121-139; Encounter between Enemies: Captivity and Ransom in the Latin Kingdom of Jerusalem, Leiden E.J.Brill, 2002; "Between Prayer and Action: Responsibility for Prisoners of War", Rivista di Storia del Christianesimo 5 (2008), pp. 73-91; "Christian-Muslim Peacemaking in the Medieval Latin East", en Dülffer, J. y Frank, R. (eds.), Peace, War and Gender from Antiquity to the Present: Cross Cultural Perspectives, Essen: Klartext Verlag, 2009, pp. 45-63; y "Peacemaking: Perceptions and Practices in the Medieval Latin East", en Kostick, C. (de.), The Crusades and the Near East: Cultural Histories, Londres y Nueva York, Routledge, 2011, pp. 229-257.

${ }^{109}$ Ligato, G., "Saladino e i prigioneri di guerra", en Cipollone, G. (ed.), La liberazione dei "captivi" tra Cristianitá e Islam: oltre la crociata e il Gihad: tolleranza e servizio umanitario, Roma, Archivio Segreto Vaticano, 2000, pp. 649-654; y La croce in catene: prigionieri e ostaggi cristiani nelle guerre di Saladino (1169-1173), Spoleto, Fondazione CISAM, 2005.

${ }^{110}$ Nicolle, D., The Military Technology of Classical Islam, Tesis Doctoral, dir. Robert Hillenbrand, University of Edinburgh, 1983.

${ }^{111}$ Nicolle, D., "Wounds, Military Surgery and the Reality of Crusading Warfare; the Evidence of Usamah's Memories", Journal of Oriental and African Studies, 5 (1993), pp. 33-46; Arms and Armour of the Crusading Era, 1050-1350: Islam, Eastern Europe and Asia (Vol. II), Londres, Greenhill Books, 1999; Medieval Warfare Source Book: Christian Europe and its Neighbours (Vol. II), Londres, Brockhampton Press, 1996; "The Manufacture and Importation of Military Equipment in the Islamic Eastern Mediterranean, $10^{\text {th }}$ to $14^{\text {th }}$ Centuries", en ES III, pp. 139-162; y Warriors and Their Weapons Around the Time of Crusades: Relationships between Byzantium, the West and the Islamic World, Burlington, Aldershot, 2002.

112 Nicolle, D., Saladin and the Saracens, Oxford, Osprey Publishing, 1986 (Men-at-Arms, 171); Hattin 1187. Saladin's Greatest Victory, Oxford, Osprey Publishing, 1993 (Campaign, 19); trad. Hattin, 1187, Madrid, Ediciones del Prado, 1999; y The Third Crusade 1191, Richard the Lionheart, Saladin and the Struggle for Jerusalem, Oxford, Osprey Publishing, 2005 (Campaign, 161); trad. La batalla por Jerusalén, Barcelona, RBA, 2011.

${ }^{113}$ Mouton, J.M., "La conquête de la Cyrénaïque et de la tripolitaine par Qaraqush: initiative individuelle ou entreprise d'État?", en Chanson-Jabeur, C., Gallet, D., Laronde, A. y Lochon, C. (eds.), Aux rivages des Syrtes: la Libye, espace et développement de l'Antiquité à nos jours, París, Centre des hautes études sur l'Afrique et l'Asie modernes, 2000, pp. 59-69. 
pañas dirigidas por los mamelucos del sultán, así como la guerra que mantuvieron con los almohades en Túnez ${ }^{114}$.

Señalaremos finalmente dos tesis doctorales de nuevos especialistas franceses en cuestiones militares. Alan Tami estudió la evolución del arte de la guerra en el periodo comprendido entre la Primera Cruzada y la muerte de Saladino, subrayando las influencias mutuas entre cruzados y musulmanes ${ }^{115}$. Mirvat Iskandar prepara su tesis sobre este mismo tema, extendiéndose hasta el final de la dinastía ayubí, basándose en las crónicas islámicas de la época ${ }^{116}$.

\section{Sociedad, aspectos religiosos y vida intelectual}

A finales del siglo XX comienza a publicar Yehoshua Frenkel, profesor del Departamento de Historia del Próximo Oriente de la Universidad de Haifa. Sus estudios están enfocados hacia el impacto de las Cruzadas en las sociedades rurales y los aspectos políticos de las fundaciones religiosas de Saladino ${ }^{117}$.

En este campo vuelve a destacar la aportación de la especialista Anne-Marie Eddé. Ha investigado aspectos tan diversos como el espacio público de Alepo, los médicos en la sociedad siria medieval, los orígenes de la población alepina en el siglo XIII y la imagen de la mujer en la época que nos ocupa ${ }^{118}$. Una parte importante de estos estudios se refiere a la cuestión religiosa. Así, podemos encontrar trabajos suyos sobre el discurso del ŷihād en tiempos de Saladino, nuevas hipótesis sobre las fundaciones piadosas en Damasco, los círculos religiosos de Jerusalén durante la dominación ayubí, o una ejecución por herejía ${ }^{119}$. Ira M. Lapidus (1937), profesor

${ }^{114}$ BAAdj, A., "Saladino y las campañas ayyubíes en el Magreb”, Al-Qantara, 34/2 (2013), pp. 267-295.

115 TAMI, A., L'art de la guerre au temps des croisades (491/1098 - 589/1193): Du théocentrisme irrationnel aux influences mutuelles et adaptations pragmatiques dans le domaine militaire, Tesis Doctoral, dirs. Sobhi Boustani y Samaha Koury, Université Bordeaux Montaigne, 2012.

${ }^{116}$ IsKandar, M., Le développement de l'art de la guerre chez les zengides et les ayyoubides (1126-1260). Syrie et Égypte à travers la vision des historiens musulmans, Tesis Doctoral, dir. Gabriel Martínez-Gros, École des Hautes Études en Sciences Sociales, en preparación.

117 Frenkel, Y., "The Impact of Crusades on Rural Society and Religious Endowments: The Case of Medieval Syria (Bilad al-Sham)", en Lev, Y. (ed.), War and Society in the Easter Mediterranean, $7^{\text {th }}-15^{\text {th }}$ Centuries, Leiden, Brill, 1997, pp.237-248; y "Political and Social Aspects of Islamic Religious Endowments (awqaf): Saladin in Cairo (1169-1173) and Jerusalem (1187-1193), BSOAS, 62/1(1999), pp. 1-20.

${ }^{118}$ EdDÉ, A.M., "L'espace public à Alep de la fin du XII ${ }^{\mathrm{e}}$ au milieu du XIII ${ }^{\mathrm{e}}$ siècle”, en HeErs, J. (ed.), Fortifications, portes de villes, places publiques dans le monde méditerranéen, París, Presses de l'Université Paris-Sorbonne, 1985, pp. 13-40; "Les médecins dans la societé syrienne du VII' /XIII' siècle", AI, 29 (1995), pp. 91-109; "Origines géographiques et ethniques de la population alépine au XIII" siècle”, en ES II, pp. 191208; e "Images de femmes en Syrie à l'époque ayyoubide", en Henriet, P. y Legras, A.M. (eds.), Au cloître et dans le monde. Femmes, hommes et societés (IXe-XV'siècle). Mélanges en l'honneur de Paulette L'Hermite-Leclercq, París, Presses de 1'Université Paris-Sorbonne, 2000, pp. 65-77; y “Hérésie et pouvoir politique en Syrie au XII ${ }^{\mathrm{e}}$ siècle: l'exécution d'al-Suhrawardī en 1191", en La religion civique à l'époque médiévale et moderne (chrétienté et islam), Roma, École Française de Rome, 1995, pp. 235-244.

119 EDDÉ, A.M., "Le paradis à l'ombre des sabres: discours sur le jihad à l'époque de Saladin", Mélanges de l'Université Saint-Joseph, 62 (2009), pp. 325-354; "Religious Circles in Jerusalem in the Ayyubid Period", en Hillenbrand, R. y Auld, S. (eds.), Ayyubid Jerusalem: The Holy City in Context, 1187-1250, Londres, Altajir Trust, 2009, pp. 195-201; y "Saladin Pious Foundations in Damascus: Some New Hypotheses", en Suleiman, Y. (ed.), Living Islamic History: Studies in Honour of Professor Carole Hillenbrand, Edimburgo, Edinburgh University Press, 2010, pp. 62-76. 
emérito de Historia Islámica en la Universidad de Berkeley también ha investigado acerca de la política religiosa en El Cairo, publicando en 1972 un estudio sobre este tema $^{120}$. Para conocer la religiosidad judía en los dominios ayubíes es imprescindible el estudio de Shelomo Dov Goitein (1900-1985), etnógrafo y arabista, especialmente conocido por su investigación de los documentos conocidos como El Cairo Geniza, hallados en una antigua sinagoga de la capital egipcia ${ }^{121}$. También es autor de un estudio sobre el desarrollo urbano en época fatimí y ayubí ${ }^{122}$. Miriam Frenkel, profesora de la Universidad Hebrea de Jerusalén y especialista en la historia del pueblo judío bajo dominio islámico, aborda en su tesis doctoral la vida de la comunidad judia en Egipto $^{123}$. También participó en uno de los congresos de Lovaina con una ponencia sobre los santuarios de Alepo y, más recientemente, ha publicado un artículo sobre la vida cotidiana en Alejandría ${ }^{124}$.

Otros expertos ya mencionados han trabajado también sobre aspectos sociales. Humphreys estudió a las mujeres de las élites de Damasco en su papel de patrocinadoras de la arquitectura religiosa, en especial su actividad fundacional ${ }^{125}$. También Yasser Tabbaa investigó la relación de la arquitectura con los círculos de poder, realizando su tesis doctoral sobre este aspecto del reinado de Nūr al-Dīn ${ }^{126}$. Posteriormente, ha publicado estudios sobre las construcciones ayubíes en Alepo ${ }^{127}$. Un estudio más reciente sobre el mecenazgo en la capital siria en los siglos XII y XIII es la tesis doctoral de François Bogard, defendida en 2011 ${ }^{128}$.

De Hirschler es un artículo sobre la aparición de una nueva élite civil en Hama ${ }^{129}$. Jean-Michel Mouton ha realizado un análisis de dos documentos inéditos sobre la pobreza en Damasco y ha estudiado la vida cotidiana en la fortaleza de Sadr ${ }^{130}$. También

${ }^{120}$ Lapidus, I.M., "Ayyubid Religious Policy and the Development of Schools of Law in Cairo", en Raymond, K. (ed.), Colloque International sur l'histoire du Cairo (27 mars-5 avril 1969), El Cairo, General Egyptian Book Organization, 1972, pp. 279-286.

${ }^{121}$ Goitein, S.D., "Religion in Everyday Life as Reflected in the Documents of the Cairo Geniza", en GoITEIN, S.D., Religion in a Religious Age, Cambridge, Association for Jewish Studies, 1974, pp. 3-17.

122 Goltein, S.D., "Urban Housing in Fatimid and Ayyubid Times", Studia Islamica, 47 (1978), pp. 5-24.

${ }^{123}$ Frenkel, M., The Jewish Community of Alexandria in the Fatimid-Ayyubid Periods: The Portrait of a Leading Elite, Tesis Doctoral, The Hebrew University, 2002.

${ }^{124}$ Frenkel, M., "Constructing the Sacred: Holy Shrines in Aleppo and its Environs", en ES VI, pp. 63-78; y "Medieval Alexandria-Life in a Port City", $A M, 26 / 1$ (2014), pp. 5-35.

${ }^{125}$ Humphreys, R.S., "Women as Patrons of Religious Architecture in Ayyubid Damascus", Muqarnas, 11(1994), pp. 35-54.

126 TABBAA, Y., The Architectural Patronage of Nur al-Din, 1146-1174, Tesis Doctoral, Institute of Fine Arts of New York University, 1983.

127 TabBaA, Y., "Circles of Power: Palace, Citadel, and City in Ayyubid Aleppo", Ars Orientalis, 23 (1993), pp. 181-200; y Constructions of Power and Piety in Medieval Aleppo, Filadelfia, Pennsylvania University Press, 1997.

${ }^{128}$ Bogard, F., Décor architectural et mécénat à Damas aux XII et XIII siècles, Tesis Doctoral, dir. Yves Porter, Université d'Aix-Marseille, 2011.

${ }^{129}$ Hirschler, K., "The Formation of the Civilian Elite in the Syrian Province: the Case of Ayyubid and Early Mamluk Hamah", MSR, 12/2 (2008), pp. 95-132.

${ }^{130}$ Mouton, J.M., “A propos de la pauvreté à Damas à l'époque ayyoubide: deux documents inédits", Archiv für Papyrusforschung, 57/1 (2011), pp. 99-108; y "Vie quotidienne et société dans les forteresses ayyoubides: le cas de la forteresse de Sadr au Sinaï", $16^{\text {th }}$ Colloquium on the History of Egypt and Syria in the Fatimid, Ayyubid and Mamluk Eras (Gante, 9/11 de mayo de 2007), inédito. 
se ha interesado por la religión islámica, publicando un trabajo sobre los ulemas egipcios de la época ayubí ${ }^{131}$. El sentimiento religioso de Saladino respecto a Jerusalén se aborda en la tesis doctoral de Arzhela Rouxel, dirigida por el conocido John Tolan ${ }^{132}$. Los religiosos han sido estudiados por Eric Geoffroy (1956), profesor del Departamento de Estudios Árabes de la Universidad de Estrasburgo y experto en sufismo. Es autor de un capítulo dedicado a ellos en una obra colectiva publicada en $2003^{133}$.

El reconocido Louis Pouzet (1928-2002), arabista y profesor de la Universidad Saint-Joseph de Beirut, es autor de un gran número de obras relativas a aspectos sociales de la Siria medieval, en las que presentó sus estudios sobre la presencia de grupos extranjeros, la visión de la mujer o la estructura religiosa de Damasco ${ }^{134}$. Otra especialista en historia social y religiosa del Próximo Oriente medieval es Danie1la Talmon-Heller (1963), profesora de la Universidad Hebrea de Jerusalén. Su tesis doctoral es un estudio sobre la sociedad y la religión en Siria entre 1154 y $1260^{135}$. Actualmente investiga la islamización de Palestina desde la conquista árabe hasta la formación de una mayoría musulmana en el siglo XIV y realiza un estudio comparativo del Corán y la Torah. Es autora de varios trabajos sobre temas religiosos y su monografía Islamic Piety in Medieval Syria fue galardonada con el Tel Aviv Book Award ${ }^{136}$. La restauración del sunismo en Egipto ha sido investigada por Gary La Viere Leiser, que elaboró una tesis doctoral sobre este tema, leída en la Universidad de Pennsylvania en $1976^{137}$. Otro grupo religioso, los coptos, ha sido estudiado por

${ }^{131}$ Mouton, J.M., "Signes de reconnaissance et signes de distinction chez les ulémas égyptiens de l'époque ayyoubide", en DÉCOBERT, C. (ed.), Valeur et distance, identités et societés en Égypte, París, Maisonneuve et Larose, 2000, pp. 151-161.

${ }^{132}$ Rouxel, A., La place de Jerusalem dans l'idéologie de Saladin, Tesis Doctoral, dir. John Tolan, Université de Nantes, 1998.

${ }^{133}$ Geoffroy, E., "Les hommes de réligion dans le Moyen-Orient ayyoubide et mamelouk (XII'-XIV siècles)", en Iogna-Prat, D. y Veinstein, G. (dirs.), Histoire des hommes de Dieu dans l'Islam et le Christianisme, París, Flammarion, 2003, pp. 93-108.

134 Pouzet, L., "Maghrébins à Damas au VII'/XIII" siècle”, BEO, 28 (1975), pp. 167-199; "Deux grammairiens à Damas au VII'/XIII" siècle", Mélanges de l'Université Saint-Joseph, 49 (1975-1976), pp. 767-784; "La descendance de l'historien 'Ali Ibn 'Asakir et ses alliances à Damas au VII'/XIII' siècle", Mélanges de l'Université Saint-Joseph, 50, 1984, pp. 515-529; “Abu Shama (599-665/1203-1268) et la societé damascaine de son temps", BEO, 37-38 (1985/1986), pp. 115-126; Damas au VII'/XIII siècle: vie et structures religieuses d'une métropole islamique, Beirut, Dar el-Mahreq, 1988; "Les madrasas et leur professeurs au VII"-XIII" siècle", Mélanges de l'Université Saint-Joseph, 52 (1991-1992), pp. 121-196; "Vision populaire de la femme en Syrie aux VI ${ }^{\mathrm{e}}$ et VII"/XII e et XIII' siècles" en FODOR, A. (ed.), Proceedings of the 14th Congress of the UEAI (Budapest, 1988), 2 vols., Budapest, 1995, part. I, pp. 295-304; y "Deux figures controversées du mysticisme à Damas au Moyen Âge: 'Ali al-Hariri (m. 645/1244) et Ibn Isra'il (m. en 677/1278)", in Proceedings of the 20th Congress of the Union Européenne des Arabisants et Islamisants, 2 vols., Budapest, 2003, part. II, pp. 61-69.

135 Talmon-Heller, D., Society and Religion in Syria from the Reign of Nur al-Din to the Mamluk Occupation (1154-1260), Tesis Doctoral, The Hebrew University of Jerusalem, 1999.

136 Talmon-Heller, D., "Religion in the Public Sphere: Rulers, Scholars and Commoners in Zangid and Ayyubid Syria (1150-1260)", en Hoexter, M. (ed.), The Public Sphere in Muslim Societies, Albany, Suny, 2002, pp. 49-64; Islamic Piety in Medieval Syria. Mosques, Cemeteries and Sermons under the Zangids and the Ayyubids (1146-1260), Leiden, Brill, 2007; e "Ilm, Shafa'ah and Barakah: The Resources of Ayyubid and Early Mamluk Ulama”, MSR, 13/2 (2009), pp. 1-23.

${ }^{137}$ La Viere Leiser, G., The Restoration of Sunnism in Egypt. Madrasas and Mudarrisun 495-647/11011249, Tesis Doctoral, University of Pennsylvania, 1976. 
Kurt J. Werthmuller, profesor asistente en la Azusa Pacific University (California).En su monografía, publicada en 2010, aborda la identidad de este colectivo en la época ayubí $^{138}$. Más recientemente, Nathan C. Hofer ha elaborado su tesis doctoral investigando el sufismo y su relación con el estado y la sociedad egipcios ${ }^{139}$.

El encuentro entre san Francisco y al-Kāmil en Damieta (1219) a fin de negociar la paz entre musulmanes y cristianos, del que apenas hay referencias en las fuentes islámicas, ha sido estudiado por Monika Lüke (1958), investigadora en la Universidad Martin-Luther de Halle, que pubicó un artículo en $1990^{140}$. Sobre esta misma cuestión encontramos trabajos más recientes de Fareed Z. Munir, profesor de Estudios Religiosos en el Siena College de Nueva York ${ }^{141}$ y de John Tolan, docente en la Universidad de Nantes ${ }^{142}$.

No hemos encontrado muchos estudios sobre la vida intelectual del periodo ayubí. Yehoshua Frenkel presentó en Lovaina una ponencia sobre la transmisión del conocimiento en el Damasco medieval ${ }^{143}$. Y Lutz Richter-Bernburg (1945) ha hecho una aproximación a la figura de 'Abd al-Lațîf al-Bagdādī (1162-1231), médico, historiador, viajero y estudioso de los monumentos pre-islámicos en Egipto, que fue toda una celebridad en su tiempo ${ }^{144}$.

\section{Arte y cultura material}

En este apartado son más abundantes las contribuciones de los arqueólogos. Entre ellos encontramos a Lorenz Korn (1966), profesor de Historia y Arqueología islámicas en la Universidad de Bamberg y autor de una tesis doctoral sobre la arquitectura ayubí en Egipto y Siria ${ }^{145}$. En los congresos de Lovaina ofreció una ponencia, inédita, sobre los palacios ayubíes sirios y otra sobre la fachada de la madrasa de al-Ṣālị Ayyūb de El Cairo, que pasó de ser una dependencia real de los fatimíes a un centro de enseñanza con los ayubíes ${ }^{146}$. Posteriormente, participó en la obra colectiva

\footnotetext{
${ }^{138}$ Werthmuller, K.J., Coptic Identity and Ayyubid Politics in Egypt, 1218-1250, El Cairo, American University of Cairo Press, 2010.

${ }^{139}$ Hofer, N.C., Sufism, State and Society in Ayyubid and Early Mamluk Egypt, 1173-1309, Tesis Doctoral, dirs. David R. Blumenthal y Vincent Cornell, Emory University, 2011.

${ }^{140}$ LÜCKE, M., "Die Friedensbestrebungen im Mittelalter-Franz von Assisi und Sultan al-Kamil”, Wissenschaftliche Zeitschrift der Universität Halle-Wittenberg, 39/2 (1990), pp. 109-112.

${ }^{141}$ MunIR, F.Z., "Sultan al-Malik Muhammad al-Kamil and Saint Francis: Interreligious Dialogue and the Meeting at Damietta", Journal of Islamic Law and Culture, 10/3 (2008), pp. 305-314.

${ }^{142}$ Tolan, J., Le Saint chez le Sultan: la recontre de François d'Assise et de l'Islam: huit siècles d'interprétation, París, Seuil, 2007.

${ }^{143}$ Frenkel, Y., "The Chain of Traditions or Transmitting Knowledge in Medieval Damascus", en ES IV, pp. $165-184$.

${ }^{144}$ Richter-Bernburg, L., "Past Glory and Present Ignorance: Abd al-Atif al-Baghdadi on Ayyubid Egypt", en $E S V$, pp. 349-367.

${ }^{145}$ Korn, L., Ayyubidische Architektur in Ägypten und Syrien: Bautätigkeit im Kontext von Politik und Gesellschaft, Tesis Doctoral, Universität Tubingen, 1998.

${ }^{146}$ Korn, L., "Burg und Palast: Ayyubidische Fürsteresidenzen in Bilad ash-Sham", $6^{\text {th }}$ Colloquium on the History of Egypt and Syria in the Fatimid, Ayyubid and Mamluk Eras (Lovaina, 15/16 de mayo de 1997) (inédito); y "The Façade of as-Salih Ayyub Madrasa and the Style of Ayyubid Architecture in Cairo", en ES III, pp. 101-122.
} 
Ayyubid Jerusalem con dos capítulos dedicados a los mosaicos y la arquitectura de la época ${ }^{147}$.

Karim Beddek, arqueólogo responsable del grupo de conservación del Aga Khan Trust for Culture que estudió las estructuras del castillo de Sahyūn, publicó en 2001 su valoración de los hallazgos, intentando determinar la función exacta del comple$\mathrm{jo}^{148}$.

Andreas Hartmann-Virnich (1960), profesor de Historia del Arte y Arqueología en la Universidad de Provenza y experto en métodos de construcción medieval en el sur de Francia y el Próximo Oriente, ha estudiado en detalle las puertas de la ciudadela de Damasco, publicando varios trabajos sobre las mismas ${ }^{149}$. Finalmente, encontramos el estudio sobre la arquitectura palaciega siria en época ayubí de Jean-Claude David, historiador de los espacios urbanos. Durante muchos años perteneció al Institut Français d'Etudes Arabes de Damasco (IFEAD), ciudad en la que realizó proyectos para la conservación del casco antiguo ${ }^{150}$.

Existen numerosos trabajos relativos a la epigrafía, en este campo debemos destacar a Moshe Sharon (1937), profesor emérito de la Universidad Hebrea de Jerusalén y experto en epigrafía árabe, que ha recopilado la totalidad de las inscripciones islámicas en Tierra Santa ${ }^{151}$. Ha publicado además algunos estudios sobre epígrafes de la época de al-Mu'azzam de Damasco ${ }^{152}$. En la actualidad se encuentra en preparación la tesis doctoral de Olivier Huonnic, en la que hace un estudio comparativo de la epigrafía almohade y ayubí1 ${ }^{153}$.

En otros apartados de cultura material contamos con las aportaciones de Paul Ba$\log$ (1900-1982), uno de los mayores expertos en monedas islámicas. Es autor de varios estudios sobre las del periodo ayubí1 ${ }^{154}$. Una de sus grandes aportaciones son los catálogos que han servido de referencia durante mucho tiempo. El dedicado a la

${ }^{147}$ Korn, L., "Ayyubid Mosaics in Jerusalem”, en Hillenbrand, R. y Auld, S. (eds.), Ayyubid Jerusalem: The Holy City in Context, Londres, Altajir Trust, 2009, pp. 377-387; y "Ayyubid Jerusalem in Perspective: the Context of Ayyubid Architecture", ibidem, pp. 388-407.

${ }^{148}$ BEDDEK, K., "Le complexe ayyubide de la citadel de Salah al-Din: bain ou palais ?", Archeologie Islamique, 11 (2001), pp. 75-90.

${ }^{149}$ Hartmann-Virnich, A., "Les portes ayyoubides de la citadelle de Damas", en Faucherre, N., Mesqui, J. y Prouteau, N. (eds.), La fortification au temps des Croisades. Actes du Colloque International de Phartenay (2002), Rennes, Presses Universitaires de Rennes, 2004, pp. 287-311; y "Régards sur un grand chantier ayyoubide: les portes de la citadelle de Damas", Arqueología de la Arquitectura, 5 (2005), pp. 217-236.

150 David, J.C., "Ayyubid Palace Architecture in Syria”, en BiancA, S. (ed.), Syria, Medieval Citadels between East and West, Génova, The Aga Khan Trust for Culture, 2007, pp. 51-70.

151 Sharon, M., Corpus Inscriptionum Arabicarum Palaestinae, Leiden, Brill, 1997-2008.

152 Sharon, M., "The Ayyubid Walls of Jerusalem. A New Inscription from the Time of al-Mu'azzam Isa", en Rosen-Ayalon, M. (ed.), Studies in Memory of Gaston Wiet, Jerusalén, The Hebrew University Magnes Press, 1977, pp. 179-193; y “Two Inscriptions of the Time of al-Mu'azzam Isa", Jerusalem Studies in Arabic and Islam, 24 (2000), pp. 508-518.

153 HuonNic, O., Etude comparative du matériel épigraphique arabe dans les centres de pouvoir almohades et ayyoubides aux VIe - VII / XII $I^{e}$ XIII $I^{e}$ siècles, Tesis Doctoral, dir. Pascal Buresi, París, EHESS, en preparación.

154 Balog, P., "Deux dinars inédits du dernier roi ayyoubide d'Égypte al-Malik al-Ashraf Abou-1-Fath Moussa”, Bulletin de l'Institut d'Egypte, 31 (1949), pp. 188-190; y "Dinars of al-Mu'azzam Shams al-Din Turanshah and al-'Aziz Tughtegin, Ayyubid Princes of the Yemen", American Numismatic Society Museum Notes, 9 (1960), pp. 237-240. 
numismática de la época que nos ocupa se publicó en $1980^{155}$. En 2001 se publica un estudio sobre las monedas conservadas en la Universidad de Chicago. Su autor, Warren C. Schultz, profesor asociado de la Universidad DePaul, es especialista en numismática islámica ${ }^{156}$. Una investigación más reciente es la realizada por Abdulsalam Albachkami en su tesis doctoral, leída en 2009, analizando colecciones inéditas de monedas ayubíes de los museos sirios ${ }^{157}$.

Las cerámicas han sido objeto de estudio por parte de Julia Gonnella, conservadora del Museo de Arte Islámico de Berlín. Participó en las excavaciones sirio-alemanas en la ciudadela de Alepo, publicando en 2000 el resultado de estos trabajos ${ }^{158}$. Y Marilyn Jenkins-Madina, conservadora emérita de Arte Islámico en el Metropolitan Museum of Art de Nueva York, ha realizado hace pocos años una obra dedicada a las cerámicas ayubíes descubiertas en Raqqa ${ }^{159}$. Podemos encontrar varias tesis doctorales que estudian este aspecto como la de Julie Monchamp, que analiza la tipología de los hallazgos realizados en la muralla ayubí de El Cairo ${ }^{160}$. Finalmente, contamos con dos tesis muy recientes, leídas ambas en 2014, que investigan sobre estos temas, la de Onas al-Salty Alkrad, que lo hace sobre las cerámicas ayubíes de Bosra ${ }^{161}$ y la de Ibrahim Shaddoud, que se centra en las de las fortalezas de Siria del norte ${ }^{162}$.

\section{REFLEXIONES FINALES}

Como se ha podido observar, los estudios sobre los ayubíes son abundantes a partir del siglo XX. Hasta entonces, y salvo por las crónicas traducidas en el Recueil, los setenta años transcurridos entre el ascenso de Saladino y la fundación del Sultanato Mameluco habían sido poco investigados. La historiografía occidental despega gracias, sobre todo, a los especialistas de la escuela francesa y se consolida definitivamente desde el último tercio de la centuria. Prueba de ello es la continuidad de los congresos organizados desde 1992 por las universidades de Lovaina y Gante, punto de encuentro de los grandes especialistas mundiales en el estudio de la historia ayubí. En sus actas podemos encontrar información realmente valiosa.

155 BALOG, P., The Coinage of the Ayyubids, Londres, Royal Numismatic Society, 1980.

156 Schultz, W.C., "Ayyubid and Mamluk Coins Preserved in the Oriental Institute of the University of Chicago”, Journal of Near Eastern Studies, 60/4 (2001), pp. 269-273.

157 Albachкаmi, M., Contribution à l'étude des monnaies ayyoubides: deux collections inédites aux musées de Damas et d'Alep, Tesis Doctoral, dir. Alastair Northedge, Université Sorbonne-Paris I, 2009.

158 Gonnella, J., "Eine neue zangidisch-aiyubidische Keramikgruppe aus Aleppo", Damaszener Mitteilungen, 11 (2000), pp. 163-177.

159 Jenkins-Madina, M, Raqqa Revisited: Ceramics of the Ayyubid Syria, Nueva York, The Metropolitan Museum of Art, 2006.

160 Monchamp, J., Contribution à l'étude de la céramique médiévale égyptienne. Chronotypologie des céramiques issues des fouilles de la muraille ayyoubide du Caire (fin Xe-début XVI siècles), Tesis Doctoral, dir. Jean-Pierre van Staëvel, Université Paris-Sorbonne IV, 2011.

161 Al-Salti Alkrad, O., Les céramiques islamiques de Bosra en Syrie du sud, VII ${ }^{e}-X V I^{e}$ siècles. Contribution à l'étude des Céramiques Islamiques dans le Bilàd al-Shàm, Tesis Doctoral, dir. Alastair Northedge, Université Sorbonne-Paris I, 2014.

162 Shaddoud, I., Céramiques des forteresses croisées, ismaïliennes, ayyoubides et mameloukes de Syrie $d u$ Nord, Tesis Doctoral, dir. Veronique Francois, Université Aix-Marseille, 2014. 
Un aspecto a destacar es la traducción de crónicas. Pese a que podemos leer muchas de ellas en idiomas occidentales, dos de las más importantes, Mufarriy al-kurūb fì akhbār Banī Ayyūb de Ibn Wāșil y Mir'āt al-Zamān fi Ta'rīj al-A 'yān de Sibț alŶawzī, siguen sin estar traducidas en su totalidad. Se ha estudiado el Mir'àt al-Zamān en tesis doctorales, pero de forma parcial.

Tampoco contamos con muchos trabajos sobre las biografías de los príncipes ayubíes. A excepción de Saladino, al-'Ādil o al-Kāmil, el resto de la familia es prácticamente desconocido en Occidente, pese al gran protagonismo que tuvieron gobernantes como al-Mu'āẓam de Damasco o al-Ašraf Mūsā, que llegó a ser uno de los miembros más poderosos de la dinastía. En los últimos tiempos se ha investigado bastante sobre algunas de sus mujeres, como Šaŷar al-Durr, sultana de Egipto, o Ḍayfa Jātūn, regente de Alepo, debido seguramente a su excepcionalidad.

En relación con la organización política de los principados ayubíes, hemos encontrado pocos estudios. Los más numerosos son los dedicados a los círculos de poder y su influencia en la administración del estado. Debemos destacar la mejor monografía, a nuestro juicio, sobre las relaciones políticas entre los sucesores de Saladino, obra de Robert Stephen Humphreys, reconocido especialista en la historia del Sultanato Mameluco. También pueden señalarse las obras de los expertos alemanes, más centradas en las relaciones diplomáticas entre francos y musulmanes de la época.

Como hemos podido comprobar en el epígrafe correspondiente, la producción bibliográfica sobre la guerra y la organización militar es abundante. A raíz del ochocientos aniversario de la batalla de Hattin se celebró en Israel un importante congreso, en el que se trataron muchos aspectos de este acontecimiento crucial. Hay que reseñar la gran labor divulgativa sobre las fortificaciones realizada por los arqueólogos de IFPO de Damasco, resultado de sus excavaciones en los antiguos territorios de la dinastía. En este campo son especialmente relevantes los estudios de Benjamin Michaudel y Cyril Yovitchitch. También contamos con las aportaciones de reputados especialistas en armamento, tácticas militares o la composición y jerarquía de los ejércitos ayubíes, como Benjamin Kedar, David Nicolle, David Ayalon o Yaacov Lev.

La sociedad y la religión de la época también han sido investigadas en profundidad. Los estudios más numerosos son los dedicados a las élites. Su patronazgo religioso se analiza en varios trabajos, entre los que destaca el que dedicó Humphreys a las damas ayubíes de Damasco. En el ámbito religioso, hemos encontrado trabajos sobre la religiosidad de Saladino, el conocido encuentro de al-Kāmil y san Francisco o la reinstauración del sunismo en Egipto, entre otros.

En el campo historiográfico, y para terminar, pueden señalarse dos obras de publicación reciente, Medieval Muslim Historians and the Franks in the Levant, trabajo colectivo editado por el británico Alex Mallet, en el que grandes estudiosos occidentales examinan la vida, los escritos y la influencia de siete historiadores árabes fundamentales para el estudio de la época ayubí; y Muslims and Crusaders: Christianity's Wars in the Middle East, 1095-1382, from the Islamic Sources del especialista Niall Christie.

Hemos realizado este trabajo pensando en su posible utilidad como punto de partida para posteriores investigaciones. Lamentablemente, aún hay algunos obstáculos en este camino. Sería fundamental que se tradujeran las grandes crónicas árabes de la 
época. Con seguridad ayudarían a conocer mejor los acontecimientos que se desarrollaron entre la formación del gran Sultanato ayubí y su desintegración total. Las excavaciones arqueológicas en Oriente Próximo han supuesto un avance considerable, pero todos conocemos la situación actual de la zona, por lo que es difícil esperar descubrimientos a corto plazo. Esperamos que el aumento de los estudios que se ha dado en los últimos años continúe y que el presente trabajo pueda contribuir a despertar el interés en nuestro país por esta importante etapa de la historia del Islam medieval.

\section{BIBLIOGRAFÍA}

AbBas, H., Le décor du stuc en Syrie à l'époque des Zengies et Ayyoubides pendant le XII et le XIII siècle, Tesis Doctoral, dir. Alastair Northedge, Université Sorbonne-Paris I, en preparación.

Abbu, A.N., The Ayyubid Domed Buildings of Syria, Tesis Doctoral, The University of Edinburgh, 1975.

Abdel-Hamid, T.G., "The Citadel of Cairo in the Ayyubid Period and the Development of Thirteenth-Century Fortifications", en O'KANE, B. (ed.), Creswell Photographs Re-examined: New Perspectives on Islamic Architecture, El Cairo, American University in Cairo Press, 2009, pp. 1-42.

Abdellatif, R., Les mosquées ayyoubides à prône au Proche-Orient, Tesis Doctoral, dir. JeanPierre van Staëvel, Université Sorbonne-Paris IV, en preparación.

Abeilen, M., The Ayyubid and Mamluk Architecture in the 'Ajlun Governorate of Jordan: an Archeological Study, Tesis Doctoral, King Saud University, 2006.

Abound, A., Anonymi auctoris chronicon ad A.C. 1234 pertinens, t. II, Corpus scriptorum christianorum orientalium, vol. 354, Scriptores Syri, t.154, Lovaina, Peeters Publishers, 1974.

Abudahesh, A., Commercial Activities in Ayyubid and Early Rasulid Yemen (569-694/11731295), Tesis Doctoral, dir. Ronald Buckley, The University of Manchester, 2004.

ABū L-FIDĀ', Taqwīn al-buldān, trad. francesa de M. Reinaud y G. de Slane, Géographie d'Aboulféda. Text arab publié d'aprés les manuscrits de Paris et de Leyde, au frais de la Société Asiatique, París, Imprimerie Nationale, 1840.

Abu-Munshar, M., "Salah al-Din's Treatment of Christians", en ABU-MUNSHAR, M. Islamic Jerusalem and its Christians. A History of Tolerance and Tensions, Londres, Tauris Academic Studies, 2007, pp. 119-142.

Abu-Munshar, M., "Salah al-Din and the Christians of Islamic Jerusalem", ibídem, pp. 143174.

Aigle, D., "Les correspondances adressées par Hülegü au prince ayyoubide de Syrie al- Malik al-Nasir Yusuf. La construction d'un modèle", en MOEZZI, M.A. y DUBOIS, J.D. (eds.), Sagesses orientales. Mélanges offerts à Michel Tardieu, Turnhout, Brepols, 2010, pp. 1-21.

Alazzam, I.M., "The Economic and Social Life in Egypt during the Reign of Ayyubid Sultan Saladin (567 AH/1171 AD-589 AH/1193 AD). A Vision through the Journey (Rihlat) of Ibn Jubayr", Asian Culture and History, 6/1 (2014), pp. 64-71.

Albachkami, A., Contribution à l'étude des monnaies ayyoubides: deux collections inédites aux musées de Damas et d'Alep, Tesis Doctoral, dir. Alastair Northedge, Université Sorbonne-Paris I, 2009.

Albertini, G., L'ultima battaglia dei Templari: Hattin e la caduta di Gerusalemme, Roma, Newton Compton, 2012. 
Allen, T., Ayyubid Architecture, Occidental (California), Solipsits Press, 1999.

Al-MaKīn, Al-mă̆mū al-mubārak, trad. francesa de A.M. Eddé y F. Micheau, Chronique des Ayyoubides de al-Makin ibn al-'Amid (602- 658/1205-1260), París, Académie des Inscriptions et Belles-Lettres, 1994.

AL-MaqRīZī, Al-Sulūk fì marifat al-duwal wa-l-mulūk, trad. inglesa de R.J.C. Broadhurst, $A$ History of the Ayyubid Sultans of Egypt translated from the Arabic of al-Maqrizi, Boston, Twayne, 1980.

Almayman, A., Richard the Lionheart and Salah al-Din al-Ayyubi: A Historical Comparative Study, Tesis Doctoral, Florida State University, 1993.

Alsalti Alkrad, O., Les céramiques islamiques de Bosra en Syrie du sud, VII -XVI siècles. Contribution à l'étude des Céramiques Islamiques dans le Bilàd al-Shàm, Tesis Doctoral, dir. Alastair Northedge, Université Sorbonne-Paris I, 2014.

AL-ŠSAYZAR̄, Kitāb nihāyat al-rutba fi țalab al-hisba, trad. francesa de W. Behrnauer, "Mémoire sur les institutions de police chez les Arabes, les Persans et les Turcs", Journal Asiatique, 16 (1860), pp. 347-392 y 17 (1861), pp. 5-76; trad. inglesa de R.P. Buckley, The Book of Islamic Market Inspector, Oxford University Press, 1999.

Alshech, E., "Islamic Law, Practice and Legal Doctrine: Exempting the Poor from the Jizya under the Ayyubids (1171-1250), Islamic Law and Society, 10/3 (2003), pp. 348-375.

AL-TARsūsī, Tabsirat arbāb al-albāb, trad. francesa de C. Cahen, "Un traité d'armurerie composé pour Saladin", BEO, 12 (1947-48), pp. 103-163.

AL-'UMARĪ, Masālik al-Abșār, trad. inglesa de E.R. Lunquist, Saladin and Richard the Lionheart. Selected Annals from "Masalik al-absar fi mamalik alamsar" by al-Umari, Lund, Lund University Press, 1996.

Amitai-Preiss, R., "Notes on the Ayyubid Inscriptions at al-Subayda (Qal'at Nimrud), Dumbarton Oaks Papers, 43 (1989), pp. 113-119.

Amitai-Preiss, R., "Hülegü and the Ayyubid Lord of Transjordan (More on the Mongol Governor of al-Karak", Archivum Eurasiae Medii Aevi, 9 (1997), pp. 5-17.

Amr, A.J., "Some Ayyubid Pottery Lamps from Rujm al-Kursi and other Related Mamluke Examples", Berytus, 32 (1984), pp. 201-210.

Amr, A.J., "A New Ayyubid Inscription from “al-Karak," Jordan", Zeitschrift des Deutschen Palästina-Vereins, 105 (1989), pp. 166-

Antrim, Z., Place and Belonging in Medieval Syria, $6^{\text {th }} / 12^{\text {th }}$ to $8^{\text {th }} / 14^{\text {th }}$ Centuries, Tesis Doctoral, Harvard University, 2005.

Antrim, Z., "Watan before al-Wataniyya; Loyalty to Land in Ayyubid and Mamluk Syria", Am, 22/2 (2010), pp. 173-190.

Arce, F., "Francisco de Asís y el sultán al-Kamil en Damieta", Tierra Santa, 51 (1976), pp. 333-342.

Asbridge, T., "Talking to the Enemy: the Role and Purpose of Negotiations between Saladin and Richard the Lionheart during the Third Crusade", Journal of Medieval History, 39/3 (2013), pp. 275-296.

Ashtor, E.,“ L'administration urbaine en la Syrie médiévale”, Rivista degli Studi Orientali, 31 (1956), pp. 73-128.

Ashtor, E., "Saladin and the Jews", Hebrew Union College Annual, 27 (1956), pp. 310-313.

Atrache, L., Die Politik der Ayyübiden: die fränkisch-islamischen Beziehungen in der ersten Hälfte des 7./13. Jahrhunderts unter besonderer Berücksichtigung des Feindbildes, Tesis Doctoral, Universität Göttingen, 1994, pub. Münster, Rhema, 1996.

Aubin-Boltanski, E., "Salah al-Din, un héros à l'épreuve: mythe et pélerinage en Palestine", Annales, Histoire, Sciences Sociales, 60/1 (2005), pp. 91-107. 
Auld, S., "Cross-Currents and Coincidences: A Perspective on Ayyubid Metalwork", en HILlenbrand, R. y Auld, S. (eds.), Ayyubid Jerusalem: The Holy City in Context, 1187-1250, Londres, Altajir Trust, 2009, pp- 45-71.

Auld, S., "The Minbar of Nur al-Din in Context", ibidem, pp. 72-93.

AUld, S., y Hillenbrand, R. (eds.), Ayyubid Jerusalem: The Holy City in Context 11871250, Londres, Altajir Trust, 2009, pp. 348-359.

Avvisar, M., Pottery of the Crusader, Ayyubid and Mamluk Periods in Israel, Jerusalén, Israel Antiquities Autority, 2005.

Ayalon, D., "Studies on the Structure of the Mamluk Army I", BSOAS, 15/2 (1953), pp. 203228.

Ayalon, D., "Studies on the Structure of the Mamluk Army II", BSOAS, 15/3 (1953), pp. 448-476.

Ayalon, D., "Studies on the Structure of the Mamluk Army III", BSOAS, 16/1 (1954), pp. 57-90.

Ayalon, D., The Impact of Firearms on the Muslim World, Princeton, Princeton University Press, 1975.

Ayalon, D., “Aspects of the Mamluk Phenomenon, Ayyubids, Kurds and Turcs”, Der Islam, 54 (1977), pp. 1-32.

Ayalon, D., "From Ayyubids to Mamluks", REI, 49 (1981), pp. 43-57.

Ayalon, D., Eunuchs, Caliphs and Sultans: A Study in Power Relationships, Jerusalén, Magnes Press, 1998.

Azimabasdi, B. The Life of Saladin, Nueva Delhi, Adam Publishers \& Distributions, 2007.

BAADJ, A., "Saladino y las campañas ayyubíes en el Magreb", Al-Qantara, 34/2 (2013), pp. 267-295.

BAER, E., Ayyubid Metalwork with Christian Images, Leiden, Brill, 1989.

BAHĀ L-Dīn, Al-Nawādir al-Sultāniyya wa'l-Mahāsin al-Yūsufiyya, trad. inglesa de D. S. Richards, The Rare and Excelent History of Saladin or "al-Nawadir al-Sultaniyya wa'lMahasin al-Yusufiyya”, Farham, Ashgate, 2002.

BALOG, P., "Deux dinars inédits du dernier roi ayyoubide d'Égypte al-Malik al-Ashraf Abou1-Fath Moussa”, Bulletin de l'Institut d'Egypte, 31 (1949), pp. 188-190.

BALOG, P., 'Dinars of al-Mu'azzam Shams al-Din Turanshah and al-'Aziz Tughtegin, Ayyubid Princes of the Yemen", American Numismatic Society Museum Notes, 9 (1960), pp. 237240.

BAlog, P., "The Ayyubid Glass Jetons and Their Use", Journal of the Economic and Social History of the Orient, 9/3 (1966), pp. 242-256.

BALOG, P., “Ayyubid Divisional Currency Issued in Egypt by al-Kamil Muhammad I", Gazette Numismatique Suisse, 27 (1977), pp. 62-67.

Balog, P., The Coinage of the Ayyubids, Londres, Royal Numismatic Society, 1980.

Bar Hebraeus, Chronicon Siryacum, trad. inglesa de E.W. Budge, The Chronography of Gregory Abu'l Faraj the Son of Aaron, the Hebrew Physician Commonly Known as Bar Hebraeus, 2 vols. Londres, Oxford University Press, 1932, reed. 1976; trad. francesa de E. Youssif, Saladin et l'epopée des Ayyoubides: chroniques syriaques, París L'Harmattan, 2010.

BARrucAnd, M., "La citadel de Damas: travaux et perspectives archèologiques", Archèologie Islamique, 11 (2001), pp. 181-187.

Barrucand, M., "Damaskus und Saladin", en WIECZOREK, A., FANSA, M. y MELLER, H. (eds.), Saladin und die Kreuzfahrer, Maguncia, Verlag Philipp von Zabern, 2005, pp. 261-264.

BARrucand, M., "Das Kairo Saladins”, ibidem, pp. 265-268. 
Bates, M.L., "Thirteenth Century Crusader Imitations of Ayyūbid Silver Coinage: a Preliminary Survey", en Kouymuan, D. K. (ed.), Near Eastern Numismatics, Iconography, Epigraphy and History (Studies in Honor of George C. Miles), Beirut American University of Beirut, 1974, pp. 393-409.

Bates, M.L., Yemen and its Conquest by the Ayyubids of Egypt (AD 1137-1202), Tesis Doctoral, University of Chicago, 1975.

Bates, M.L., "The Function of Fatimid and Ayyubid Glass Weights", Journal of the Economic and Social History of the Orient, 24/1 (1981), pp. 63-92.

Bauden, F., “Taqī al-Dīn Aḥmad ibn 'Alī al-Maqrīzī”, en Mallet, A. (ed.), Medieval Muslim Historians and the Franks in the Levant, Leiden, Brill, 2014, pp.161-200.

BeDDek, K., "Le complexe ayyoubide de la citadel de Salah al-Din: bain ou palais ?", Archeologie Islamique, 11 (2001), pp. 75-90.

Bellver, J., "Ibn Barrağān and Ibn 'Arabī on the prediction of the capture of Jerusalem in 583/1187 by Saladin", Arabica, 61/3-4 (2014), pp. 252-286.

Blair, S., "The Power of the Word: Ayyubid Inscriptions in Jerusalem", en Hillenbrand, R. y Auld, S. (eds.), Ayyubid Jerusalem: The Holy City in Context, 1187-1250, Londres, Altajir Trust, 2009, pp. 118-128.

Blaum. P., "Eagles in the Sun: the Ayyubids after Saladin", IJKS, 13/1 (1999), pp. 105-180.

Bogard, F., Décor architectural et mécénat à Damas aux XII et XIII ${ }^{e}$ siècles, Tesis Doctoral, dir. Yves Porter, Université d'Aix-Marseille, 2011.

Bosworth, C.E., "Recruitment, Muster and Review in Medieval Islamic Armies", en Parry, V.J. y YAPP, M.E. (eds.), War, Technology and Society in the Middle East, Londres, Oxford University Press, 1975, pp. 59-77.

Boudot-Lamotte, A, Contribution à l'étude de l'archerie musulmane principalement d'après le manuscrit d'Oxford Bodléienne Huntington no 264, Damasco, IFEAD, 1968.

Brand, C.M., "The Bizantines and Saladin, 1185-1192: Opponents of the Third Crusade", Speculum, 37/2 (1962), pp. 167-181.

Brentues, S., "Orthodoxy”, Ancient Sciences, Power and the Madrasa (college) in Ayyubid and Early Mamluk Damascus, Berlín, Max Planck Institut für Wissenschaftsgeschichte, 1997.

Brentjes, S., “Ayyubid Princes and Their Scholarly Clients from the Ancient Sciences", en Fuess, A. y Hartung, H.P. (eds.), Court Cultures in the Muslim World: Seventh to Nineteenth Centurie, Londres, Routledge, 2011, pp- 326-356.

Bresc, C., "Quseir al-Qadim: A Hoard of Islamic Coins from the Ayyubid Period", Revue Numismatique, 164 (2008), pp. 407-436.

BrinNER, W.J., "Some Ayyubid and Mamluk Documents from Non-Archival Sources", Israel Oriental Studies, 2 (1972), pp. 117-143.

Brown, R.B., "Faunal Remains from Excavations in the Ayyubid Palace at Shawbak Castle in Southern Transjordan", Berytus, 52 (2009), pp. 169-198.

Burgoyne, M.H., "1187-1260: The Furtest Mosque (al-Masjid al-Aqsa) under Ayyubid Rule", en Grabar, O. y Kedar, B.Z. (eds.), Where Heaven and Earth Meet: Jerusalem's Sacred Esplanade, Jerusalén, Yad Ben-Zvi Press, 2009, pp. 151-174.

Burns, R., "Saladin and the Ayyubids", en Burns, R., Damascus: A History, Londres, Routledge, 2005, pp. 170-194.

Bylinski, J., "Qal'at Shirkuh at Palmyra. A Medieval Fortress Reinterpreted", BEO, 51 (1999), pp. 151-208.

Bylinski, J., "Three Minor Fortresses in the Realm of Ayyubid Rulers of Homs in Syria: Shumaimis, Tadmur (Palmyra) and al-Rahba", en Faucherre, N., Mesqui, J. y Prouteau, N. 
(eds.), La fortification au temps des Croisades, Actes du Colloque International de Phartenay. (2002), Rennes, Presses Universitaires de Rennes, 2004, pp. 151-164.

CAHEN, C., "La Djazira au milieu du treizième siècle d'après 'Izz ad-Dīn Ibn Chaddad", REI, 8 (1934), pp. 109-128.

CAHEN, C., "Indigènes et croisés. Quelques mots à propos d'un médecin d'Amaury et de Saladin", Syria, 15/4 (1934), pp. 351-360.

CAHEN, C., "Une chronique chiite au temps des croisades", Comptes rendus des séances de l'Académie des Inscriptions et Belles-Lettres, 79/3 (1935), pp. 258-269.

CAhen, C., La Syrie du Nord à l'époque des Croisades et la principauté franque d'Antioche, París, Paul Geuthner, 1940.

Cahen, C., "Une source pour l'histoire des croisades: les mémoires de Sa'd ad-Dîn Ibn Hamawiya Juwaïni”, Bulletin de la Faculté des Lettres de Strasbourg, 28/7 (1950), pp. 320337.

CAHEN, C., "L'évolution de l'iqtā du IX ${ }^{\mathrm{e}}$ au XIII" siècle: Contribution à une histoire comparée des sociétés médiévales", Annales, Economies, Sociétés, Civilisations, 8/1 (1953), pp. 2552.

Cahen, C., "Le régime des impôts dans le Fayyum ayyoubide", Arabica, 3 (1956), pp. 8-30.

CAhen, C., "La Chronique des Ayyoubides d'al-Makīn b. al-“Amīd”, BEO, 15 (1958), pp. 109-184.

CAHEn, C., "Un traité financier inédit d'époque fatimide-ayyoubide", Journal of the Economic and Social History of the Orient, 5/1 (1962), pp. 139-159.

CAHEn, C., "Abdallatīf al-Baghdādī, portraitiste et historien de son temps", BEO, 23 (1970), pp. 101-128.

CAHEN, C., "Les marchands étrangers au Caire sous les Fatimides et les Ayyubides", Colloque international sur l'histoire du Caire, 1969, El Cairo, General Egyptian Book Organization, 1972, pp. 97-101.

CAHEN, C., "Les changements techniques militaires dans le Proche-Orient médiéval et leur importance historique", en PARRY, V.J. y YAPP, M.E. (eds.), War, Technologie and Society in the Middle East, Londres, Oxford University Press, 1975, pp. 113-124.

CAHEn, C., "Le testament d'al-Malik as-Salih Ayyub, mélanges offerts a H. Laoust", BEO, 29 (1977), pp. 97-114.

CAHEN, C., Makhzūmiyyāt. Études sur l'histoire économique et financière de l'Égypte médiévale, Leiden, E.J. Brill, 1977.

CAHEN, C., Les peuples musulmans dans l’histoire médiévale, Damasco, Institut Français, 1977.

CAHEn, C., "Monetary Circulation in Egypt at the Time of Crusades and the Reform of alKamil", en Udovitch, A. (ed.), The Islamic Middle East, 700-1900: Studies in Economic and Social History, Princeton, Darwin Press, 1981, pp. 315-333.

Cahen, C., Orient et Occident au temps des Croisades, París, Aubier Montaigne, 1983.

CAHEn, C., "La circulation monétaire en Egypte des Fatimides aux Ayyubides", Revue Numismatique, 26 (1984), pp. 208-217.

Cahen, C., "Sur le Ta'rīkh Șāliḥ̄i d'Ibn Wāṣil. Notes et extraits”, en Sharon, M. (ed.), Studies in Islamic History and Civilization in Honour of Professor David Ayalon, Leiden, Brill, 1986, pp. 507-516.

CAHEN, C., "Pour un programme de traductions des chroniques arabes du Proche-Orient au temps des croisades", Journal des Savants, 1 (1987), pp. 13-26.

Chamberlain, M., Knowledge and Social Practice in Medieval Damascus, 1190-1350, Cambridge, Cambridge University Press, 1994. 
Chamberlain, M., "The Crusader Era and the Ayyubid dinasty", en Petry, C.F. (ed.), The Cambridge History of Egypt, vol. 1: Islamic Egypt, 640-1517, Cambridge, Cambridge University Press, 1998, pp. 211-241..

Christie, N., Muslims and Crusaders: Christianity's Wars in the Middle East, 1095-1382, from the Islamic Sources, Abington, Routledge, 2014.

Christie, N., "Cosmopolitan Trade Centre or Bone of Contention? Alexandria and the Crusades", 487-857/1095-1453", AM, 26/1 (2014), pp. 49-61.

Claverie, P.V., "Un domaine controversé de l'histoire des croisades: les relations d'estime de Saladin avec les chrétiens au XII ${ }^{\mathrm{e}}$ siècle", $21^{\text {st }}$ Colloquium on the History of Egypt and Syria in the Fatimid, Ayyubid and Mamluk Eras (Gante, 9/11 de mayo de 2012), inédito.

Coвb, P.M., Usama ibn Munqidh. Warrior Poet of the Age of Crusades, Oxford, Oneworld Publications, 2005.

Contadini, A., "Ayyubid Illustrated Manuscripts and Their North Jaziran and Abbasid Neighbours", en Hillenbrand, R. y Auld, S. (eds.), Ayyubid Jerusalem: The Holy City in Context, 1187-1250, Londres, Altajir Trust, 2009, pp. 179-194.

Creswell, K.A.C., The Muslim Architecture of Egypt II. Ayyubids and Early Bahrite Mamluks, AD. 1171-1326, Oxford, Clarendon Press, 1959.

Cutler, A., "St. Francis and the "Noble Heathen": Notes on Gift Practice in the Ayyubid Era", en Schmidt, K. y Wolf, G. (eds.), Islamic Artefacts in the Mediterranean World: Trade, Gift Exchange and Artistic Transfer, Venecia, Marsilio Editori, 2010, pp. 45-52.

Da'Adli, T., Kedar, B.Z. y Weksler-Bdolah, S., "La Madrasa Afdaliyya/Maqam alShaykh'id: un exemple de l'architecture ayyoubide à Jerusalem", Revue Biblique, 119/2 (2012), pp. 271-287.

Dabboura, G. y Umran, H., The Citadel of Damascus. A Thirteenth Century Fortress of the Sultan al-'Adil, Damasco, H. Umram y G. Dabboura, 1997.

Dahlmanns, F.J., Al-Malik al-'Adil: Ägypten und der Vordere orient in den Jahren 589/1193 bis 615/1218: ein Beitrag zur ayubidischen Geschichte, Tesis Doctoral, Universität Giessen, 1975.

DAngles, P., "La refortification d'Afamiyya-Qal'at al-Mudiq sous le sultanat ayyoubide d'Alep (fin XII ${ }^{\mathrm{e}}$ - mi. XIII ${ }^{\mathrm{e}}$ s.)", en Faucherre, N., Mesqui, J. y Prouteau, N. (eds.), La fortification au temps des Croisades, Actes du Colloque International de Phartenay. (2002), Rennes, Presses Universitaires de Rennes, 2004, pp. 189-204.

DAvid, J.C., "Ayyubid Palace Architecture in Syria”, en BIANCA, S. (ed.), Syria, Medieval Citadels between East and West, Génova, The Aga Khan Trust for Culture, 2007,pp. 51-70.

Dayoub, B., Sourdel, D., Sourdel-Thomine, J. y Mouton, J.M., “Témoignages epigraphiques damascains sur un sayh méconnu d'époque ayyoubide", Der Islam, 87/1 (2012), pp. 185 203.

Den Heiser, J., "Coptic Historiography in the Fatimid, Ayyubid and Early Mamluk Periods", Medieval Encounters, 2/1 (1996), pp. 67-98.

Denoix, S., "Le Caire des ayyoubides et des mamelouks (1174-1517)", en RaYmond, A. (dir.), Le Caire, París, Citadelles et Mazenod, 2000, pp. 147-275.

De Vries, B., "Hesban in the Ayyubid and Mamluk Periods", en Merling, D. y Geraty, L. (eds.), Hesban after 25 Years, Berrien Springs, Andrews University, 1994, pp. 151-166.

Drory, J., "Al-Nāsir Dāwūd: A Much Frustrated Ayyubid Prince”, AM, 15/2 (2003), pp. 161187.

Drory, J., "The Early Decades of Ayyubid Rule", en Kraemer, J. (ed.), Perspectives on Maimonides: philosophical and historical Studies, Oxford, The Littman Library of Jewish Civilization, 2008, pp. 295-302. 
Drory, J., "The 1229 Agreement between Friedrich II and al-Malik al-Kamil: New Data", $19^{\text {th }}$ Colloquium on the History of Egypt and Syria in the Fatimid, Ayyubid and Mamluk Eras, (Gante, 5/7 de mayo de 2010), inédito.

DucAtez, G., "Aden aux XII et XIII" siècles selon Ibn al-Mugawir: son passé légendaire, son histoire sous les Zuray'ïdes et les Ayyoubides, son site, ses monuments et ses aménagements", $A I, 38$ (2004), pp. 158-200.

DuCÊNE, J.C., "Méthodes d'arpentages en Egypte ayyoubide et mamelouke", $21^{\text {st }}$ Colloquium on the History of Egypt and Syria in the Fatimid, Ayyubid and Mamluk Eras (Gante, 9/11 de mayo de 2012), inédito.

Duncan, D.L., "Scholary Views of Shajarat al-Durr: A Need of Consensus", Arab Studies Quarterly, 22/1 (2000), pp. 51-69.

EDDÉ, A.M., "L'espace public à Alep de la fin du XII e au milieu du XIII" siècle”, en HeERS, J. (ed.), Fortifications, portes de villes, places publiques dans le monde méditerranéen, París, Presses de l'Université de Paris-Sorbonne, 1985, pp. 13-40.

EdDÉ, A.M., “La prise d'Alep par les Mongols en 1260”, Quaderni di Studi Arabi, 5-6 (19871988), pp. 226-240.

EdDÉ, A.M.,"Sous les mourailles d'Alep: assaillants et défenseurs de 351/962 à 658/1260", en Le combattant au Moyen Age, Actes du XVIII Congrés de la Societé des Historiens Médiévistes de l'Enseignement Supérieur Public (Montpellier, 1987), Nantes, CDI Éditions, 1991, pp. 63-75.

EDDÉ, A.M.,"Les relations commerciales entre Alep et Venise au VII -XIII' siècles", REI, 59 (1991), pp. 165-186.

EDDÉ, A.M.,"Une grande famille de shafiites alépins: les Banū 1-'Ağamī aux XII'-XIII' siècles", Revue du Monde Musulman et de la Méditerranée, 62, 1991, pp. 61-71.

EDDÉ, A.M.,"Notes sur la fiscalité de l'état ayyoubide d'Alep au XIII siècle", en ConTAMine, P. (ed.), Commerce, Finances et Societé (XIe-XIVe siècles), París, Presses de l'Université Paris-Sorbonne, 1993, pp. 247-262.

EDDÉ, A.M.,"Les attributs de la souveraineté ayyoubide en Syrie du Nord", en $3^{\text {rd }}$ International Colloquium on the History of Egypt and Syria in the Fatimid, Ayyubid and Mamluk Eras, (Lovaina 5/6 de mayo de 1994), inédito.

EDDÉ, A.M., "Villes en fête au Proche-Orient au XIII" siècle", en Villes et sociétés urbaines au Moyen Âge, Hommage à M. le Professeur Jacques Heers, París, Presses de l'Université de Paris Sorbonne, 1994, pp. 71-79.

EDDÉ, A.M.,"Hérésie et pouvoir politique en Syrie au XII" siècle: l'exécution d'al-Suhrawardī en 1191", en La religion civique à l'époque médiévale et moderne (chrétienté et islam), Roma, École Française de Rome, 1995, pp. 235-244.

EDDÉ, A.M.,"Les médecins dans la societé syrienne du VII" /XIII" siècle”, AI, 29 (1995), pp. 91-109.

EDDÉ, A.M., “Quelques institutions militaires ayyoubides”, en ES I, pp. 163-174.

EDDÉ, A.M.,La principauté ayyoubide d'Alep (579/1183-658/1260), Tesis Doctoral, dir. Dominique Sourdel, Université Sorbonne-Paris IV, 1995; pub. Stuttgart, Franz Steiner Verlag, 1999.

EdDÉ, A.M., “Claude Cahen et les sources arabes des croisades”, Arabica, 43 (1996), pp. 8997.

EdDÉ, A.M., "Saint Louis et la Septième Croisade vus par les auteurs arabes", Cahiers de Recherches Médiévales (XII" $/ X V^{E}$ s.), 1 (1996), pp. 65-92.

EdDÉ, A.M.,"Kurdes et Turcs dans l'armée ayyoubide de Syrie du Nord”, en LEV, Y. (ed.), War and Society in the Eastern Mediterranean, $7^{\text {th }}-15^{\text {th }}$ Centuries, Leiden, Brill, 1997, pp. 225-236. 
EDDÉ, A.M., “Origines géographiques et ethniques de la population alépine au XIII" siècle”, en ES II, pp. 191-208.

EDDÉ, A.M.,"La vision des Francs dans les sources musulmanes à l'époque des croisades (1099-1250)", en Islam et monde latin (milieu Xe-milieu XIII ${ }^{e}$ ), Espaces et enjeux, París, ADHE, 2000, pp. 61-80.

EDDÉ, A.M.,"Images de femmes en Syrie à l'époque ayyoubide”, en HENRIET, P. y LEGRAS, A.M.(eds.), Au cloître et dans le monde. Femmes, hommes et societés (IXe- $X V^{e}$ siècle). Mélanges en l'honneur de Paulette L'Hermite-Leclercq, París, Presses de l'Université Paris-Sorbonne, 2000, pp. 65-77.

EdDÉ, A.M.,L'Orient au temps des Croisades, présentation, traduction et notes, París, Flammarion, 2002.

EdDÉ, A.M.,Saladin, París, Flammarion, 2008, trad. inglesa Harvard University Press, 2011.

EDDÉ, A.M.,"Le paradis à l'ombre des sabres: discours sur le jihad à l'époque de Saladin", Mélanges de l'Université Saint-Joseph, 62 (2009), pp. 325-354.

Eddé, A.M.,"Religious Circles in Jerusalem in the Ayyubid Period", en Hillenbrand, R. y Auld, S. (eds.), Ayyubid Jerusalem: The Holy City in Context, 1187-1250, Londres, Altajir Trust, 2009, pp. 195-201.

EdDÉ, A.M., "Saladin, l'image du prince dans les textes arabes du Moyen Âge", Microscoop, 4 (2009), pp. 16-17.

Eddé, A.M., "Saladin Pious Foundations in Damascus: Some New Hypotheses", en Suleiman, Y. (ed.), Living Islamic History: Studies in Honour of Professor Carole Hillenbrand, Edimburgo, Edinburgh University Press, 2010, pp. 62-76.

EdDÉ, A.M.,"Bilad al-Sham, from the Fatimid Conquest to the Fall of the Ayyubids (359658/970-1260)", en FIERRO, M. (ed.), New Cambridge History of Islam. Vol. II: The Western Islamic World, Eleventh to Eighteenth Centuries, Cambridge, Cambridge University Press, 2010, pp. 159-200.

EdDÉ, A.M.,"Saladin, le Syrien”, L'Histoire, 375 (2012), pp. 54-57.

EdDÉ, A.M.,"Kamāl al-Dīn 'Umar Ibn al-“Adīm”, en MALlet, A. (ed.), Medieval Muslim Historians and the Franks in the Levant, Leiden, Brill, 2014, pp. 109-135.

Ehrenkreutz, A., "Extracts from the Technical Manual on the Ayyubid Mint in Cairo", $B S O A S, 15 / 3$ (1953), pp. 423-447.

Ehrenkreutz, A., "The Place of Saladin in the Naval History of the Mediterranean Sea in the Middle Ages", JAOS, 75 (1955), pp. 100-116.

Ehrenkreutz, A., "The Crisis of the Dinar in the Egypt of Saladin", JAOS, 76 (1956), pp. 178-184.

Ehrenkreutz, A., "Saladin's coup d'état in Egypt", en Hanna, S. (ed.), Medieval and Middle Eastern Studies in Honour of Aziz Suryal Atiya, Leiden, Brill, 1972, pp. 144-157.

Ehrenkreutz, A., Saladin, Albany, State University of New York Press, 1972.

Ehrenkreutz, A., "Saladin as homo oeconomicus", Hamdard Islamicus, 22 (1999), pp. 7-16.

Ehrlich, M., "The Battle of Hattin: A Chronicle of a Defeat Foretold?", Journal of Medieval Military History, 5 (2007), pp. 16-32.

Ehrlich, M., "Saint Catherine's Day Miracle - the Battle of Montgisard", Journal of Medieval Military History, 11 (2013), pp. 95-105.

Elad, A., Medieval Jerusalem and Islamic Worship: Holy Places, Ceremonies, Pilgrimage, Leiden, Brill, 1995.

EL-AzHARI, T. "The Office of atabeg in Syria under the Nurids and the Ayyubids", AM, 11 (1999), pp. 47-66.

El-Azhari, T. "Dayfa Khatun, Ayyubid Queen of Aleppo (1236-1242)", Annals of Japan Association for Middle East Studies, 15 (2000), pp. 27-55. 
El-AzHARI, T. "The Influence of Eunuchs in the Ayyubid Kingdom”, en ES IV, pp. 127-142.

Elbeheiry, S., Les Institutions de l'Egypte au temps des Ayyoubides, Tesis Doctoral, dir. Claude Cahen, Université Sorbonne-Paris IV, 1971.

El-IskANDARI, M., L'enseignement et le pouvoir dans la societé musulmane à l'époque des Fatimites et des Ayyoubides (358-648/969-1250), Tesis Doctoral, dir. Djafar Moinfar, Université Sorbonne-Paris VII, 1988.

Ellis, R.W., L'historiographie almohade et ayyoubide: une étude comparative, Tesis Doctoral, dir. Ludvik Kalus, Université Sorbonne-Paris IV, 2001.

El-Moctar, M., "Saladin in the Sunni and Shi'a Memories”, en Paul, N. y Yeager, S. (eds.), Remembering the Crusades. Myth, Image and Identity, Baltimore, The Johns Hopkins University Press, 2012, pp. 197-214.

Ephrat, D. y KabHA, M.D., "Muslim Reactions to the Frankish Presence in Bilād al-Shām: Intensifying Religious Fidelity within the Masses", AM, 15/1 (2003), pp. 47-58.

FourdRIN, J.P., "L'association de la niche et de l'archère dans les fortifications élevées en Syrie entre le VI et le XII siècle", Syria. Archéologie, Art et Histoire, 75 (1998), pp. 279-294.

Franz, K., "The Ayyubid and Mamluk Revaluation of the Hinterland and Western Historical Cartography", MSR, 12/2 (2008), pp. 133-158.

Franz, K., "Tribes, Castles and Beyond: Mapping Spatial Relations in Ayyubid Syria", 20"th Colloquium on the History of Egypt and Syria in the Fatimid, Ayyubid and Mamluk Eras, (Gante, 11/13 de mayo de 2011), inédito.

Frenkel, M., The Jewish Community of Alexandria in the Fatimid-Ayyubid Periods: The Portrait of a Leading Elite, Tesis Doctoral, The Hebrew University, 2002.

Frenkel, M., "Constructing the Sacred: Holy Shrines in Aleppo and its Environs", en ES VI, pp. 63-78.

Frenkel, M., "Al-Raqqa in Fatimid and Ayyubid Times: Evidences from the Cairo Geniza", $22^{\text {th }}$ Colloquium on the History of Egypt and Syria in the Fatimid, Ayyubid and Mamluk Eras (Gante, 15/17 de mayo de 2013), inédito.

Frenkel, M., "Medieval Alexandria-Life in a Port City”, AM, 26/1 (2014), pp. 5-35.

Frenkel, Y., "The Impact of Crusades on Rural Society and Religious Endowments: The Case of Medieval Syria (Bilad al-Sham)", en LEV, Y. (ed.), War and Society in the Eastern Mediterranean, $7^{\text {th }}-15^{\text {th }}$ Centuries, Leiden, Brill, 1997, pp. 237-248.

Frenkel, Y., "Political and Social Aspects of Islamic Religious Endowments (awqāf): Saladin in Cairo (1169-1173) and Jerusalem (1187-1193), BSOAS, 62/1(1999), pp. 1-20.

Frenkel, Y., "The Chain of Traditions or Transmitting Knowledge in Medieval Damascus", en $E S I V$, pp. 165-184.

Frenkel, Y., "Ayyubid and Mamluk Historiography, Eyewitness Account by Several Contemporaries", en Van Steenbergen, J. y D'Hulster, K. (eds.), Continuity and Change in the Realms of Islam: Studies in Honour of Professor U. Vermeulen, Lovaina, Uitgeverij Peeters, 2008, pp. 245-261.

Friedman, Y., "Women in Captivity and their Ransom in the Crusader Period", en Goodich, M., Menasche, S. y Schein, S. (eds.), Cross Cultural Convergences in the Crusader Period, Nueva York, Peter Lang, 1995, pp. 75-87.

Friedman, Y., "The Ransom of Captives in the Latin Kingdom of Jerusalem", en BaLARD, M.(ed.), Autour de la Première Croisade, Paris, Publications de la Sorbonne, 1996, pp. 177-189.

Friedman, Y., "Captivity and Ransom-The Experience of Women”, en LAMBERT, S. y EdGIngton, S. (eds.), Gendering the Crusades, Cardiff: University of Wales Press, 2001, pp. 121-139. 
Friedman, Y., Encounter between Enemies: Captivity and Ransom in the Latin Kingdom of Jerusalem, Leiden E.J.Brill, 2002.

Friedman, Y., "Between Prayer and Action: Responsibility for Prisoners of War", Rivista di Storia del Christianesimo 5 (2008), pp. 73-91.

Friedman, Y., "Christian-Muslim Peacemaking in the Medieval Latin East", en DülfFer, J. Y Frank, R. (eds.), Peace, War and Gender from Antiquity to the Present: Cross Cultural Perspectives, Essen: Klartext Verlag, 2009, pp. 45-63.

Friedman, Y., "Peacemaking: Perceptions and Practices in the Medieval Latin East", en Kosтіск, C. (de.), The Crusades and the Near East: Cultural Histories, Londres y Nueva York, Routledge, 2011, pp. 229-257.

Gabrieli, F., Il Saladino, Florencia, Fussi, 1948.

Gabrieli, F., Storici arabe delle Crociate, Turín, Einaudi Editore, 1963; trad. ing. E. Costello, Arab historians of the Crusades, Nueva York, Routledge, 2010; trad. francesa V. Pâques, Chroniques arabes des Croisades, París, Sindbad-Actes Sud, 2014.

GaL, Z., "Saladin's Dome of the Victory at the Horns of Hattin", en en KedAr, B.Z. (ed.), The Horns of Hattin: Proceedings of the $2^{\text {nd }}$ Conference of the Society for the Study of Crusades and the Latin East, (Jerusalem and Haifa, 2/6 July 1987), Jerusalén, Yad Izhak Ben-Zvi, 1992, pp. 213-215.

Garcin, J.C. (ed.), États, sociétés et cultures du monde musulman médiéval, $X^{e}$-XVe siècle, 3 vols., París, P.U.F., 1995-2000.

GARDiol, J.B., "Le palais ayyoubide de la citadelle de Damas, premières données archéologiques et nouvelles observations", BEO, suplemento 53/54 (2003), pp. 47-59.

Gaube, H., "Der islamischen Grabbau und das Mausoleum des Salah al-Din in Damaskus", en Bollman, B. (ed.), Damaskus-Aleppo: 5000 Jahre Stadtentwicklung in Syrien, Maguncia, Philipp von Zabern, 2000, pp. 246-249.

Gaudefroy-Demombynes, M., "Une lettre de Saladin au calife almohade", en Mélanges René Basset. Études nord-africaines et orientales, 2 vols., París, E. Leroux, 1923-1925, vol. II, pp. 279-304.

Geoffroy, E., "Les hommes de réligion dans le Moyen-Orient ayyoubide et mamelouk (XII XIV siècles)", en Iogna-Prat, D. y Veinstein, G. (dirs.), Histoire des hommes de Dieu dans l'Islam et le Christianisme, París, Flammarion, 2003, pp. 93-108.

GibB, H., "The Arabic Sources for the Life of Saladin", Speculum, 25 (1950), pp. 58-72.

GiBB, H., "The Achievement of Saladin", Bulletin of the John Rylans Library, 35 (1952), pp.25-52.

Gibb, H., "The Ayyubids", en Setton, K.M. (ed.), A History of the Crusades, 5 vols., Madison, University of Wisconsin Press, 1955, vol. II, pp. 693-714.

Gibb, H., "The Armies of Saladin", en Shaw, S.J. y Polk, W.R. (eds.), Studies on the Civilization of Islam, Boston, Beacon Press, 1962, pp. 74-90.

GiBB, H., The Life of Saladin from the Works of Imad al-Din and Baha al-Din, Oxford, Clarendon Press, 1973.

GibB, H., Saladin: Studies in Islamic History, Beirut, Arab Institute for Research and Publishing, 1974.

GiBB, H. et al. (eds.) Encyclopaedia of Islam, 4 vols., Leiden, Brill (1913-1936).

Gilbert, J.E., "Institutionalization of Muslim Scholarship and Professionalization of the 'Ulamā' in Medieval Damascus”, Studia Islamica, 52 (1980), pp. 105-134.

Gillingham, J., Richard I, Bury St. Edmunds, St. Edmondsbury Press, 2002: trad., Ricardo Corazón de León, Madrid, Sílex, 2012. 
GoiteIn, S.D., "Religion in Everyday Life as Reflected in the Documents of the Cairo Geniza”, en Goitein, S.D., Religion in a Religious Age, Cambridge, Association for Jewish Studies, 1974, pp. 3-17.

GorteIn, S.D., "Urban Housing in Fatimid and Ayyubid Times", Studia Islamica, 47 (1978), pp. 5-24.

Goitein, S.D., "Geniza Sources for the Crusader Period: A Survey", en Outremer: Studies in the History of the Crusading Kingdom of Jerusalem Presented to Joshua Prawer, Jerusalén, Yad Izhak Ben-Zvi Publications, 1982, pp. 306-323.

Gonnella, J., "Eine neue zangidisch-aiyubidische Keramikgruppe aus Aleppo”, Damaszener Mitteilungen, 11 (2000), pp. 163-177.

Gonnella, J., "The Citadel of Aleppo: Recent Studies", en Kennedy, H. (ed.), Muslim Military Architecture in Greater Syria, Leiden, Brill, 2006, pp. 176-183.

Gonnella, J., "Die aiyubidische und mamluken Zitadelle von Aleppo, Residenzstadt und Begestigung”, en Piana, M. (ed.), Burgen und Städte der Kreuzzugszeit, Petersberg, Michael Imhof Verlag, 2008, pp. 139-148.

Gottschalk, H.L., Al-Malik al-Kamil von Egypten und seine Zeit: eine Studie zur Gestichte Vorderasiens und Egyptens in der ersten Hälfte des 7/13 Jahrhunderts, Weisbaden, O. Harrasowitz, 1958.

Gril, D., La Risāla de Șafì al-Dīn Ibn Abī l-Manșūr Ibn Zāfir. Biographies des maîtres spirituels connus par un cheikh égyptien du VIIe/XIIIe siècle, El Cairo, Institut Français d'Archéologie Orientale du Caire, 1986.

Gubser, P., Saladin: Empire and Holy War, Piscataway, Gorgias Press, 2010.

HADDAD, K., Les lettres de chancellerie du Qadi al-Fadil (529/1134-597/1199), secrétaire de Saladin, Tesis Doctoral, dir. Jean-Michel Mouton, École Pratique des Hautes Études, en preparación.

Hafsi, I., Correspondence officielle et privée d'al-Qadi al-Fadil, Tesis Doctoral, dir. Mohammed Arkoun, Université Sorbonne-Paris IV, 1979.

Halm, H., "The Re-establishment of Sunni fiqh in Jerusalem under Ayyubid Rule", en The Third International Conference on Bilad al-Sham (19/24 april 1980), 3 vols., Amán, Yarmouk University, 1983, vol. I, pp. 111-115.

Hamblin, W.J., "Saladin and Muslim Military Theory", en Kedar, B.Z. (ed.), The

Horns of Hattin: Proceedings of the $2^{\text {nd }}$ Conference of the Society for the Study of Crusades and the Latin East, (Jerusalem and Haifa, 2/6 July, 1987), Jerusalén, Yad Izhak Ben-Zvi, 1992. pp. 228-238.

Hanisch, H., Die ayyubidischen Toranlangen der Zitadelle von Damaskus. Ein Beitrag zur Kenntnis des mittelalterlichen Festungsbauwesen in Syrien, Wiesbaden, Ludwig Reichert, 1996.

Hanisch, H., "Die ayyubidischen Wehranlagen der Zitadelles von Harran und Damaskus. Ein Vergleich", en ES III, pp. 61-87.

HANisch, H., "The Works of al-Malik al-'Adil in the Citadel of Harran", en FAUCHERRE, N., Mesqui, J. y Prouteau, N. (eds.), La fortification au temps des Croisades. Actes du Colloque International de Phartenay. (2002), Rennes, Presses Universitaires de Rennes, 2004, pp. 165-178.

Hanisch, H., "Bauweisen und Maßarten der aiyubidischen Wehrbauten der Zitadelle von Kairo", $16^{\text {th }}$ Colloquium on the History of Egypt and Syria in the Fatimid, Ayyubid and Mamluk Eras (Gante, 9/11 de mayo de 2007), inédito.

Hanisch, H., "Zu zwei Problemen bei der Untersuchung der ayyubidischen Torbauten der Zitadelle von Damaskus", en ES VI,pp. 79-94. 
Hartmann, J., Die Persönlichkeit des Sultans Saladin im Urteil der abendländischen Quellen, Tesis Doctoral, Universität Jena, 1933; pub. Berlín, Verlag E. Ebering, 1933.

Hartmann-Virnich, A., "Les portes ayyoubides de la citadelle de Damas", en Faucherre, N., Mesqui, J. y Prouteau, N. (eds.), La fortification au temps des Croisades. Actes du Colloque International de Phartenay. (2002), Rennes, Presses Universitaires de Rennes, 2004, pp. 287-311.

HARTMANN-VIRNich, A., "Régards sur un grand chantier ayyoubide: les portes de la citadelle de Damas", Arqueología de la Arquitectura, 5 (2005), pp. 217-236.

Hawari, M.K., Ayyubid Jerusalem (1187-1250), an Architectural and Archaeologic Study, Oxford, Archeopress, 2007.

HaWARI, M.K., "Muslim-Jewish Relations in Ayyubid Egypt, 1171-1250”, en MA'oz, M. (ed.), The Meeting of Civilizations: Muslims, Christians and Jewish, Brighton, Sussex Academic Press, 2009, pp. 66-74.

Hawari, M.K., “Ayyubid Monuments in Jerusalem”, en Hillendrand, R. y Auld, S. (eds.), Ayyubid Jerusalem: The Holy City in Context, 1187-1250, Londres, Altajir Trust, 2009, pp. 216-275.

Heidemann, S., “Un décret d'al-Malik al-'Adil relatif aux moines du Mont Sinaï”, AI, 31 (1997), pp. 81-107.

Heidemann, S., "Economic Growth and Currency in Ayyubid Palestine", en Hillenbrand, R. y Auld, S. (eds.), Ayyubid Jerusalem: The Holy City in Context, 1187-1250, Londres, Altajir Trust, 2009, pp. 276-300.

HeIn, H.A., Beiträge zur ayyubidischen Diplomatik, Tesis Doctoral, dir. H.R. Roemer, Universität Freiburg im Breisgau, 1968; pub. Freiburg im Breisgau, Schwartz, 1971.

Herde, P., "Historische Wendepunkte: die Schlachten von Hattin (3.-4. Juli 1187) und 'Ain Galut (3. September 1260)”, en PIANA, M. (ed.), Burgen und Städte der Kreuzzugszeit, Petersberg, Michael Imhof Verlag, 2008, pp. 43-46.

Hillenbrand, C., The Crusades. Islamic Perspectives, Edimburgo, Edinburgh University Press, 1999.

Hillenbrand, C., "The Evolution of the Saladin Legend in the West", Mélanges de l'Université Saint Joseph, 58 (2005), pp. 1-13.

Hillenbrand, C., “Ayyubid Jerusalem. Historial Introduction", en Hillenbrand, R. y Auld, S. (eds.), Ayyubid Jerusalem: The Holy City in Context, 1187-1250, Londres, Altajir Trust, 2009, pp. 1-21.

Hillenbrand, R., “The Art of Ayyubids. An Overview”, ibidem, pp. 22-44.

Hillenbrand, R., "The Ayyubid Aqsa: Decorative Aspects", ibídem, pp. 301-326.

Hillenbrand, R. y Auld, S. (eds.), Ayyubid Jerusalem: The Holy City in Context 1187-1250, Londres, Altajir Trust, 2009.

Hilmy, M., "Some Notes on Arabic Historiography during the Zengid and Ayyubid Periods (521/1127-648/1250)", en Lewis, B. y Holt, P.M. (eds.), Historians of the Middle East, Londres, Oxford University Press, 1962, pp. 79-97.

Hindley, G., Saladin, Nueva York, Barnes \& Noble Books, 1976.

Hirschler, K., "Social Contexts of Medieval Arabic Historical Writing: Court Scholars versus Ideal/Withdrawn Scholars -Ibn Wāsil and Abū Shāma", en ES IV, pp. 311-332.

Hirschler, K., Medieval Arabic Historiography: Autors as Actors, Londres, Routledge, 2006. Hirschler, K., "He is a Child and this Land is a Borderland of Islam: Under-age Rule and the Quest for Political Stability in the Ayyubid Period”, AM, 19/1 (2007), pp. 29-46.

Hirschler, K., "The Formation of the Civilian Elite in the Syrian Province: the Case of Ayyubid and Early Mamluk Hamah", MSR, 12/2 (2008), pp. 95-132. 
Hirschler, K., "Reading Certificates (sama'at) as a Prosopographical Source: Cultural and Social Practices of an Elite Family in Zangid and Ayyubid Damascus", en Görke, A. e Hirschler, K. (eds.), Manuscript Notes as Documentary Sources, Würzburg, Ergon Verlag, 2011, pp. 73-92.

Hirschler, K., "Ibn Wāșil: An Ayyūbid Perspective on Frankish Lordships and Crusades", en Mallet, A. (ed.), Medieval Muslim Historians and the Franks in the Levant, Leiden, Brill, 2014, pp. 136-160.

Hofer, N.C., Sufism, State and Society in Ayyubid and Early Mamluk Egypt, 1173-1309, Tesis Doctoral, dirs. David R. Blumenthal y Vincent Cornell, Emory University, 2011.

Hoffman, E.R., "Christian-Islamic Encounters on Thirteenth-Century Ayyubid Metalwork: Local Culture, Authenticity, and Memory," Gesta, 43/2 (2004), pp. 129-142.

Holt, P.M., Eastern Mediterranean Lands in the Period of Crusades, Oxford, Aris \& Phillips Imprint, 1978.

Holt, P.M., "From Saladin to the Mongols, the Ayyubids of Damascus, 1193-1260 by R. Stephen Humphreys", BSOAS, 41/3 (1978), pp. 592-595.

HoLt, P.M., "Saladin and His Admirers", BSOAS, 46 (1983), pp. 228-238.

Holt, P.M., The Age of Crusades: The Near East from the Eleventh Century to 1517, Londres, Longman, 1986.

Holt, P.M., "The Sultan as Ideal Ruler: Ayyubid and Mamluk Prototipes", en WoodHEAD, C. (ed.), Suleyman the Magnificent and His Age. The Ottoman Empire in the Early Modern World, Londres, Longman, 1995, pp. 122-137.

Humphreys, R.S., The Ayyubids of Damascus, 589-658/1193-1260: a Principality in Medieval Syria, Tesis Doctoral, dir. Andrew Ehrenkreutz, University of Michigan, 1969; pub. From Saladin to the Mongols, the Ayyubids of Damascus, 1193-1260, Albany, University of New York Press, 1977.

Humphreys, R.S., "The Emergence of the Mamluk Army”, Studia Islamica, 45 (1977), pp. 67-99.

Humphreys, R.S., "The Emergence of the Mamluk Army (Conclusion)", Studia Islamica, 46 (1977), pp. 147-182.

Humphreys, R.S., "Broadhurst, R.J.C. A History of the Ayyubidd Sultans of Egypt translated from the Arabic of al-Maqrizi, Boston, Twayne, 1980", Reseña, JAOS, 103/2 (1983), pp. 449-452.

Humphreys, R.S., "Politics and Architectural Patronage in Ayyubid Damascus", en Bosworth, C. (ed.), The Islamic World from Classic to Modern Times, Essays in Honour of Bernard Lewis, Princeton, Darwin Press, 1989, pp. 151-171.

Humphreys, R.S., "Legitimacy and Political Stability in Islam in the Age of the Crusades", en Messier, R. Y Dajani-Shakeel, H.(eds.), The Jihad and its Times: Dedicated to Andrew Stefan Ehrenkreutz, Michigan, University of Michigan Library, 1991, pp. 5-13.

Humphreys, R.S., "Women as Patrons of Religious Architecture in Ayyubid Damascus", Muqarnas, 11 (1994), pp. 35-54.

HumphreYs, R.S., "Ayyubids, Mamluks and the Latin East in the Thirteenth Century", MSR, 2 (1998), pp. 1-17.

Humphreys, R.S., Towards a History of Aleppo and Damascus in the Early Middle Ages (6351260), Tokio, University of Tokyo, 1998.

HumphrEYs, R.S., "The Origins of the Ayyubid Confederation”, IJKS, 13/1 (1999), pp. 63-93.

HuONNIC, O., Etude comparative du matériel épigraphique arabe dans les centres de pouvoir almohades et ayyoubides aux VI $I^{e} V I I^{e} / X I I^{e}-X I I I^{e}$ siècles, Tesis Doctoral, dir. Pascal Buresi, París, EHESS, en preparación. 
Iвn Aві̄ L-DAmm, Kitāb al-šamārīhh fì l-tawārīh, trad. inglesa de D. S. Richards, "The Crusade of Frederick II and the Hamāh Succesion. Extracts from the Chronicle of Ibn Abī alDamm, Kitāb al-šamārīh fì l-tawārīh̆”, BEO, 45 (1993), pp. 183-200.

IBN Al-'ADīm, Bughyat al-țalab fì tarīj Halab, trad. inglesa de D. Morray, An Ayyubid Notable and His World: Ibn al- 'Adìm and Aleppo as Portrayed in His Biograpical Dictionary, "Bughyat al-talab fi ta'rik Halab”, Leiden, Brill, 1994.

IBN AL-AT̄īe, Al-Kāmil fì l-Ta'rìj, trad. inglesa de D.S. Richards, The Chronicle of Ibn al-Athīr for Crusading Period from “al-Kämil fi l-Ta'rīkh”. Part. II: The Years 541-589/1146-1193: The Age of Nur al-Din and Saladin, Farham, Ashgate, 2010 y Part. III: The Years 589629/1193-1231: The Ayyubids after Saladin and the Mongol Menace, Farham, Ashgate, 2010.

IBn Al-Furāt, Ta'rīj al-Duwal wa'l-Mulūk, trad. inglesa de V. Lyons, M.C. Lyons y J.S.C. Riley Smith, Ayyubids, Mamluks and Crusades. Selections from the Tärīkh al-Duwal wa'lMulūk of Ibn al-Furāt, 2 vols., Cambridge, W. Heffer \& Sons, 1971.

IBN JALLIKĀN, Kitāb wafayāt al-a yān wa anbā' abnā' al-zamān, trad. inglesa de M.G. De Slane, Ibn Khallikan's Biographical Dictionary, (Kitāb wafayāt al-a 'yān wa anbā' abnā', al-zamān), 4 vols., Paris-Londres, Oriental Translation Found, 1843-1871.

IBN ŠSADDĀD 'Izz Al-Dīn, Al-A 'lāq al-hnațīra fì dikr umarā' al-Šām wa l-Ğazīra, trad. francesa de A.M. Eddé, Description de la Syrie du Nord, Damasco, IFEAD, 1984.

IBN WĀṣıL, Mufarrîy al-kurūb fì akhbār Banī Ayyūb, trad. alemana de M. Rahim, Die Chronik des ibn Wasil. Gamal ad-Din Muhammad ibn Wasil. Mufarrig al-Kurub fi Ahbar Bani Ayyub. Kritische Edition des letzten Tells (646/1248-659/1261) mit Kommentar; Untergand der Ayyubiden und Beggin der Mamlukenherrschaft, Tesis Doctoral, dir. Tilman Seidensticker, Friedrich Schiller Universität Jena, 2006, pub. Die Chronik des Ibn Wasil, Weisbaden, O. Harrasowitz, 2010.

Ibn Ŷubar, Rihla, trad. italiana de Celestino Schiaparelli, Viaggio in Ispagna, Sicilia, Siria e Palestina, Mesopotamia, Arabia, Egitto, compiuto nel secolo XII, Roma, Casa editrice italiana, 1906; trad. francesa de M. Gaudefroy-Demombynes, Voyages, "Rihla”, Ibn Jubayr, 4 vols., Paris, P. Geuthner, 1949-1965; trad. inglesa de R.J.C. Broadhurst, The Travels of Ibn Jubayr, Londres, Cape, 1952; trad. española de F. Má́llo Salgado, A través del Oriente: el siglo XII ante los ojos, Rihla, Barcelona, Ediciones del Serbal, 1988; reed. 2007.

'IMĀD Al-Dīn Al-IșFahĀNī, Al-Fath al-qussī fì'l-fath al-qudsī, trad. alemana de J. Kraemer, Der Sturz Königreichs Jerusalem (583/1187): in der Darstellung des Imad ad-Din al-Katib al-Isfahan, Wiesbaden, O. Harrasowitz, 1952; trad. francesa de H. Massé, Conquête de la Syrie et de la Palestine par Saladin, "al-Fath al-Qussi fi al-Fath al-Qudsī”, Imād al-Dīn al-Isfahāni, París, Académie des Inscriptions et Belles-Lettres, 1972.

ImAMudDin, S.M., "Diwan al-Insha (Chancery in Later Medieval Egypt), with Special Reference to Later Fatimid, Ayyubid and Mamluk Decrees Dated 528-894 H./1134-1489 A.C.", Journal of the Pakistan Historical Society, 28 (1980), pp. 63-77.

Imbert, F., "Une nouvelle inscription de Saladin sur la muraille ayyoubide du Caire", AI, 42 (2008), pp. 409-421.

Irwin, R., "Saladin and the Third Crusade: A Case Study in Historiography and the Historical Novel”, en Bentley, M. (ed.), Companion to Historiography, Londres, Routhledge, 1997, pp. 130-142.

IsKANDAR, M., Le développement de l'art de la guerre chez les zengides et les ayyoubides (1126-1260). Syrie et Égypte à travers la vision des historiens musulmans, Tesis Doctoral, dir. Gabriel Martínez-Gros, École des Hautes Études en Sciences Sociales, en preparación.

Ismail, K., La biographie du sultan ayyoubide al-Malik al-Kamil, 615-635 de l'Hégire (12181238), Tesis Doctoral, Université Sorbonne, 1939. 
JÄCKEL, D., "Saladin und Antichrist. Das andere Bild vom Ayyubidensultan im 12 Jahrhundert", en Brandes, W. y Schmieder, F. (eds.), Antichrist: Konstruktionen von Feindbildern, Berlín, Akademie Verlag, 2010, pp. 117-134.

JACKSOn, D.E.P., "The Crisis in the Holy Land in 1260", The English Historical Review, 95/376 (1980), pp. 482-513.

JACKSON, D.E.P., "The Crusades of 1239-1241 and Their Aftermath", BSOAS, 50/1 (1987), pp. 31-60.

JACKSON, D.E.P., "Some Preliminary Reflections on the Chancery Correspondence of the Qadi al-Fadil", en ES I, pp. 207-218.

JACKSON, D.E.P., "1193-1993. An Appreciation of the Career of Saladin”, ibidem, pp. 219-228.

JACKson D.E.P. y Lyons, M.C., Saladin: The Politics of the Holy War, Cambridge, Cambridge University Press, 1982.

JACKSON, S.A., Islamic Law and the State. The Constitutional Jurisprudence of Shihāb al-Dīn al-Qarāfi, Leiden, Brill, 1996.

JACOBY, D., "Byzantine Trade with Egypt fom the Mid-tenth Century to the Fourth Crusade", Thesaurismata, 30 (2000), pp. 25-77.

JACOBY, D., "The Supply of War Materials to Egypt in the Crusader Period", Jerusalem Studies in Arabic and Islam, David Ayalon in Memoriam, 25 (2001), pp. 102-132.

JADON, S., "The Physicians of Syria during the Reign of Salah al-Din (570-589/1174-1193)", Journal of the History of Medecine and Allied Sciences, 25 (1970), pp. 323-340.

James, B., Saladin et les Kurdes: perception d'un groupe au temps des Croisades, París, L'Harmattan, 2006.

JAMES, B., "Saladin et la diversité: à la tête d'un empire mosaïque", Histoire Antique et Médievale, 25 (2011), pp. 24-29.

James, D., "Qur'ans and Caligraphers of the Ayyubids and the Zangids", en HillenBrand, R. y Auld, S. (eds.), Ayyubid Jerusalem: The Holy City in Context 1187-1250, Londres, Altajir Trust, 2009, pp. 348-359.

JARrAH, S., "Sūq al-Ma'rifa: An Ayyubid Hanbalite Shrine in al-Haram al-Sharīf”, Muqarnas, 15 (1998), pp. 71-100.

Jarrah, S., "From Monastic Cloisters to Sahn: The Transformation of the Open Space of the Masjid al-Aqsa Under Saladin", en Hillenbrand, R. y Auld, S. (eds.), Ayyubid Jerusalem: The Holy City in Context, 1187-1250, Londres, Altajir Trust, 2009, pp. 360-376.

Jenkins-Madina M., Raqqa Revisited: Ceramics of the Ayyubid Syria, Nueva York, The Metropolitan Museum of Art, 2006.

Johnson, G.K., "St. Francis and the Sultan”, Mission Studies, 18/1 (2001), pp. 146-163.

JuBB, M., "Saladin vu par Guillaume de Tyr et par l'Eracles: changement de perspectives", en Balard, M. (ed.), Autour de la première croisade. Actes du Colloque de la Society for the Study of the Crusades and the Latin East (Clermont-Ferrand, 22/25 de junio de 1995), París, Publications de la Sorbonne, 1996, pp. 443-451.

JubB, M., The Legend of Saladin in Western Literature and Historiography, Lewiston, Mellen Press, 2000.

KARIMI, H., 'L'origine iranienne de Fakhr al-Din Yusof, émir ayyoubide, instigateur de la paix avec Frédéric II pendant la VI ${ }^{\mathrm{e}}$ Croisade", en La signification du bas Moyen Âge dans l'histoire et la culture du monde musulman / Actes du 8ème Congrès de l'Union européenne des Arabisants et Islamisants, Aix-en Provence, septembre 1976, Aix-en-Provence, Édisud, 1978, pp. 109-115.

KhadiJa, L., "Designs on Painted Ayyubid/Mamluk Pottery from Rujm el-Kursi, 1990 Season", Annual of the Department of Antiquities of Jordan, 36 (1992), pp. 345-356. 
Khalidi, T., Arabic Historical Thought in the Classical Period, Cambridge, Cambridge University Press, 1994.

Kedar, B.Z., Crusade and Mission: European Approaches toward the Muslims, Princeton, Princeton University Press, 1988.

KedAr, B.Z., "The Subjected Muslims of the Frankish Levant", en Powell, J.M. (ed.), Muslims under Latin Rule 1100-1300, Princeton, Princeton University Press, 1990, pp. 135174.

Kedar, B.Z., "The Battle of Hattin Revisited", en Kedar, B.Z. (ed.), The Horns of Hattin: Proceedings of the $2^{\text {nd }}$ Conference of the Society for the Study of Crusades and the Latin East, (Jerusalem and Haifa, 2/6 July 1987), Jerusalén, Yad Izhak Ben-Zvi, 1992, pp. 190207.

KedAr, B.Z., "A Melkite Physician in Frankish Jerusalem and Ayyubid Damascus: Muwaffaq al-Dīn Ya qūb b. Siqlāb", en The Franks in the Levant, $11^{\text {th }}$ to $14^{\text {th }}$ Centuries, Londres, Variorum, 1993, pp. 113-126.

KedAr, B.Z., "Croisade et Jihâd vus par l'ennemi, une étude des perceptions mutuelles des motivations", en Balard, M. (ed.), Autour de la première croisade. Actes du Colloque de la Society for the Study of the Crusades and the Latin East (Clermont-Ferrand, 22/25 de junio de 1995), París, Publications de la Sorbonne, 1996, pp. 345-355.

Kedar, B.Z., “A Western Survey of Saladin's Forces at the Siege of Acre”, en Kedar, B.Z., Riley-Smith, J. e Hiestand, R. (eds.), Montjoie. Studies in Crusade History in Honour of Hans Eberhard Mayer, Aldershot, Ashgate Publishing Ltd., 1997, pp. 113-122.

Kedar, B.Z., DA'Adli, T. y Weksler-Bdolah, S., "La Madrasa Afdaliyya/Maqam alShaykh'id: un exemple de l'architecture ayyoubide à Jerusalem", Revue Biblique, 119/2 (2012), pp. 271-287.

KING, G. "Archaeological Fieldwork at the Citadel of Homs, Syria, 1995-1999", Levant, 34/1 (2002), pp. 39-58.

Klein-Franke, F., "What Was the Fatal Disease of al-Malik al-Salih Najm al-Din Ayyub?", en Sharon, M. (ed.), Studies in Islamic History and Civilization in Honour of Professor David Ayalon, Leiden, Brill, 1986, pp. 153-158.

KohlBerg, E., "A Melkite Physician in Frankish Jerusalem and Ayyubid Damascus: Muwaffaq al-Din Yaqub b. Siqlab", en Kedar, B.Z. Yudovitch, A.L. (eds.), The Medieval Levant: Studies in Memory of Eliyahu Ashtor, Haifa, University of Haifa, 1988, pp. 113-126.

KÖHLER, M., Allianzen und Verträge zwischen fränkischen und islamischen Herrschern im Vorderen Orient. Eine Studie über das zwischenstaatliche Zusammenleben vom 12. bis ins 13. Jahrhundert, Berlin, De Gruyter, 1991, trad. inglesa Alliances and Treaties between Frankish and Muslim Rulers in the Middle East. Cross-Cultural Diplomacy in the Period of the Crusades, Leiden, Brill, 2013.

Korn, L., "Burg und Palast: Ayyubidische Fürsteresidenzen in Bilad ash-Sham", $6^{\text {th }}$ Colloquium on the History of Egypt and Syria in the Fatimid, Ayyubid and Mamluk Eras (Lovaina, 15/16 de mayo de 1997), inédito.

Korn, L., "Die Bauten Saladins: Kairo, Damaskus und Jerusalem in der Baupolitik des anNasir Salah ad-Din Yusuf ibn Ayyub", en ES II, pp. 209-235.

Korn, L., Ayyubidische Architektur in Ägypten und Syrien: Bautätigkeit im Kontext von Politik und Gesellschaft (564-658/1169-1260), Tesis Doctoral, Universität Tubingen, 1998; pub. Heidelberg, Heidelberger Orientverlag, 2004.

Korn, L., "Ayyubidische Bautätigkeit aus der Sicht der Chronisten", $7^{\text {th }}$ Colloquium on the History of Egypt and Syria in the Fatimid, Ayyubid and Mamluk Eras (Lovaina, 12/13 de mayo de 1998), inédito. 
KoRn, L., "Tradition und Innovation in der ayyubidischen Architektur in Ägypten”, Mitteilungen des Deutschen Archäologischen Instituts Kairo, 55 (1999), pp. 265-292.

Korn, L., "The Façade of as-Salih Ayyub Madrasa and the Style of Ayyubid Architecture in Cairo", en ES III, pp. 101-122.

Korn, L., "The Structure of Architectural Patronage in Ayyubid Jerusalem", en Phalitzsch, J. y Korn, L. (eds.), Governing the Holy City: The Interaction of Social Groups in Jerusalem between the Fatimid and the Ottoman Period, Wiesbaden, Reichert Verlag, 2004, pp. 71-89.

Korn, L., “Ayyubid Mosaics in Jerusalem”, en Hillenbrand, R. y Auld, S. (eds.), Ayyubid Jerusalem: The Holy City in Context 1187-1250, Londres, Altajir Trust, 2009, pp. 377-387.

Korn, L., "Ayyubid Jerusalem in Perspective; the Context of Ayyubid Architecture", ibidem, pp. 388-407.

La Monte, J.L., “Taqi ed-Din, Prince of Hamah”, The Muslim World, 31 (1941), pp.149- 160.

Lane-Poole, S., The Mohammedan Dinasties: Chronological and Genealogical Tables with Historical Introductions, Westminster, A. Constable, 1894.

Lane-Poole, S., Saladin, Nueva York, Fred \& deFau, 1898.

Lane-Poole, S., Saladin and the Fall of the Kingdom of Jerusalem, Londres, G.P. Putnam's Sons, 1898.

LAPIDUS, I.M., "Ayyubid Religious Policy and the Development of Schools of Law in Cairo", en Raymond, K. (ed.), Colloque International sur l'histoire du Cairo (27 mars $/ 5$ avril 1969), El Cairo, General Egyptian Book Organization, 1972, pp. 279-286.

La Viere Leiser, G., The Restoration of Sunnism in Egypt. Madrasas and Mudarrisun 495647/1101-1249, Tesis Doctoral, University of Pennsylvania, 1976.

LEAF, W., "Developments in the System of Armorial Insignia during the Ayyubid and Mamluk Periods", Palestine Exploration Quarterly, 115 (1983), pp. 61-74.

Leder, S., Al-Sawwās, M. y Al-SāGIRGī, M., Mu ' 'gam al-sammā 'āt al-dimašqūyat 550-750 h. Les certificats d'audition à Damas: 1155-1349, Damasco, IFEAD, 1996.

Leder, S., Al-SAwwās, M. y Al-SĀGIRGī, M., Mu'ğam al-samā'āt al-Dimašqiyya. Șuwar al mantūtūtāt al-muntahabat min sanat 550 ilā 750 h. $/ 1155$ ilā 1349 h. Recueil de documents: fac-similés des certificats d'audition à Damas 550 - 750h. / 1135 - 1344, Damasco, IFEAD, 2000.

Leder, S., Dorpmueller, S. y Helmy, M., Chancery and Diplomatics Exemplified by the Correspondence of al-Qadi al-Fadil, Orient Institut Beirut, en preparación: http://www. orient-institut.org/index.php?id=93.

LeISER, G., "Hanbalism in Egypt before the Mamluks", Studia Islamica, 54 (1981), pp. 155181.

Le Strange, G., Palestine Under the Moslems: A Description of Syria and the Holy Land from A.D. 650 to 1500, Londres, A.P. Watt, 1890.

LEV, Y., Saladin in Egypt, Leiden, Brill, 1998.

Lev, Y., "Charity and Social Practice in Egypt and Syria from the Ninth to the Twelfth Century", Jerusalem Studies in Arabic and Islam, 24 (2000), pp. 472-507.

LEV, Y., "Prisoners of War during the Fatimid-Ayyubid Wars with the Crusaders", en GERVERS, M. y POWELL, J.M. (eds.), Tolerance and Intolerance: Social Conflict in the Age of Crusades, Nueva York, Syracuse University Press, 2001, pp. 11-27.

Lev, Y., "Charity and Justice in Medieval Islam", Rivista degli Studi Orientali, 76 (2003), pp. $1-16$.

Lev, Y., Charity, Endowments and Charitable Institutions in Medieval Islam, Gainesville, University Press of Florida, 2005. 
LEv, Y., "Infantry in Muslim Armies during the Crusades", en PRYOR, J. (ed.), Logistics of Warfare in the Age of the Crusades: Proceedings of a Workshop held at the Centre for Medieval Studies (University of Sydney, 30 September to 4 October 2002), Aldershot, Ashgate, 2006, pp. 185-208.

Lev, Y., "The Dismemberment of the Fatimid State and the Emergence of the New Ayyubid Elite in Egypt", en ES V, pp. 129-152.

Lev, Y., "Saladin's Economic Policies and the Economy in the Ayyubid Egypt", ibidem, pp. 307- 348.

Lev, Y., "The Fatimid Caliphate (358-567/969-1171) and the Ayyubids in Egypt (567648/1171-1250)", en Fierro, M. (ed.), New Cambridge History of Islam. Vol. II: The Western Islamic World, Eleventh to Eighteenth Centuries, Cambridge, Cambridge University Press, 2010, pp. 201-236.

Lev, Y., "The Transition from the Ayyubids to the Mamluks: Ibn Wasil's Account", $19^{\text {th }}$ Colloquium on the History of Egypt and Syria in the Fatimid, Ayyubid and Mamluk Eras, (Gante, $5 / 7$ de mayo de 2010), inédito.

Lev, Y., "Direct Quest for Justice in Fatimid-Ayyubid Egypt", $22^{\text {th }}$ Colloquium on the History of Egypt and Syria in the Fatimid, Ayyubid and Mamluk Eras, (Gante, 15/17 de mayo de 2013), inédito.

Levanoni, A., "The Mamluk Conception of Sultanate", International Journal of Middle East Studies, 26/3 (1994), pp. 373-392.

Levanoni, A., "Sagar al-Durr, a Case of Female Sultanate in Medieval Islam", en ES III, pp. 194-209.

LEwIS, B., "Saladin and the Assassins", BSOAS, 15/2 (1953), pp. 239-245.

Lewis, B., "Maimonides, Lionheart and Saladin", Eretz Israel, 7 (1963), pp. 70-75.

LEwIs, B., "Claude Cahen", Proceedings of the American Philosophical Society, 141/2 (1977), pp. 217-220.

Ligato, G., "Continuitá ed eccezioni nella leggenda di Saladino", Quaderni medievali, 36 (1993), pp. 6-29.

Ligato, G., "Saladino e i cristiani, La Terra Santa, 70 (1994), pp. 43-47.

Ligato, G., "Corrado di Monferrato e la corte di Saladino: il punto di vista islamico", en Rondonini, G.S. (ed.), Il Monferrato, crovecia politico, economico e culturale tra Mediterraneo e Europa. Atti del Convegno Internazionale, (Ponzone, 9/12 giugno 1998),

Génova, Universitá degli Studi di Genova, 2000, pp. 111-140.

Ligato, G., "Saladino e I prigioneri di guerra", en Cipollone, G. (ed.), La liberazione dei "captivi" tra Cristianitá e Islam: oltre la crociata e il Gihad: tolleranza e servizio umanitario, Roma, Archivio Segreto Vaticano, 2000, pp. 649-654.

Ligato, G., La croce in catene: prigionieri e ostaggi cristiani nelle guerre di Saladino (11691173), Spoleto, Fondazione CISAM, 2005.

Little, D.P., "Jerusalem under the Ayyubids and Mamluks, 1189-1516 AD.", en Asali, K.J. (ed.), Jerusalem in History, Nueva York, Olive Branch Press, 1990, pp. 177-199.

Lohrmann, D., "Das Himmelszelt des Sultans al-Kamil von 1232 für Kaiser Friedrich II", Historische Zeitschrift, 294/2 (2012), pp. 297-327.

LüCKE, M., "Die Friedensbestrebungen im Mittelalter-Franz von Assisi und Sultan al- Kamil", Wissenschaftliche Zeitschrift der Universität Halle-Wittenberg, 39/2 (1990), pp. 109-112.

Lynch, J.A., The Uses of Saladin in Medieval and Early Modern Literature, Tesis Doctoral, dir. Juan Carlos Conde, Indiana University, 2011.

Lyons, M.C. y Jackson D.E.P., Saladin: The Politics of the Holy War, Cambridge, Cambridge University Press, 1982. 
Lyons, M.C. y Melville, C.P., "Saladin's Hattin Letter", en Kedar, B.Z. (ed.), The Horns of Hattin: Proceedings of the $2^{\text {nd }}$ Conference of the Society for the Study of Crusades and the Latin East, (Jerusalem and Haifa, 2/6 July 1987), Jerusalén, Yad Izhak Ben-Zvi, 1992, pp. 208-212.

McClary, R., "Adoption and Absorption: The Penetration of the Ayyubid Aesthetic into the Architecture of 13th Century Saljuq Konya", $22^{\text {th }}$ Colloquium on the History of Egypt and Syria in the Fatimid, Ayyubid and Mamluk Eras (Gante, 15/17 de mayo de 2013), inédito.

Mackenzie, N.D., A Topographical Study of Cairo under the Ayyubids, Tesis Doctoral, The University of Michigan, 1986.

Mackenzie, N.D., "The Fortifications of al-Qahira under the Ayyubids", en Messier, R. Y Dajani-ShakeeL, H.(eds.), The Jihad and its Times: Dedicated to Andrew Stefan Ehrenkre$u t z$, Michigan, University of Michigan Library, 1991, pp.71-94.

MackenZIE, N.D., "Ayyubid-Mamluk Archaeology of the "Aljun Area, A Preliminary Typology”, Annual of the Deparment of Antiquities of Jordan, 46 (2002), pp. 615-620.

MAKARIOU, S. (dir.), L'Orient de Saladin: l'art des Ayyoubides: exposition presentée à l'Institut du monde arabe, Paris (23 octobre 2001 au 10 mars 2002), París, Gallimard, 2001.

Mallet, A., "Islamic Historians of the Ayyubid Era and Muslim Rulers from the Early Crusader Period: A Study in the Use of History", AM, 24/3 (2012), pp. 241-252.

Mallet, A., Popular Muslim Reactions to the Franks in the Levant, 1097-1291, Londres, Ashgate, 2014.

Mallet, A., "Sibṭ Ibn al-Jawzī”, en Mallet, A. (ed.), Medieval Muslim Historians and the Franks in the Levant, Leiden, Brill, 2014, pp. 84-108.

Marcotte, R.D., "Suhrawardī al-Maqtūl, the Martyr of Aleppo", Al-Qantara, 22/2 (2001), pp. 395-419.

Martínez-Gros, G. (ed.), Pays d'Islam et Monde latin X'-XIII siècle. Textes et documents, Lyon, Presses Universitaires de Lyon, 2001.

Marshall, C., Warfare in the Latin East, 1192-1291, Cambridge, Cambridge University Press, 1994.

MaYer, H.E., "Saladin by Andrew Ehrenkreutz", Reseña, Speculum, 49/4 (1974), pp. 724727.

Meinecke, M., "Salkhad, exemple de ville-forteresse islamique”, en Dentzer, J.M. (ed.), Le Djebel al-'Arab: histoire et patrimoine au musée de Suweida, París, Editions Recherche sur les Civilisations, 1991, pp. 93-99.

MeLČÁK, M., "Reconstruction of the Lost Ayyubid Waqf. Madrasa al-Shāmīya al-Juwwānīya in Damascus as Depicted in the Fatāwā of Taqī al-Dīn al-Subkī (d. 756/1355)”, Archiv Orientální, 80/1 (2012), pp. 1-39.

Melville, C.P. y LYONS, M.C., "Saladin's Hattin Letter”, en KEDAR, B.Z. (ed.), The Horns of Hattin: Proceedings of the $2^{\text {nd }}$ Conference of the Society for the Study of Crusades and the Latin East, (Jerusalem and Haifa, 2/6 July 1987), Jerusalén, Yad Izhak Ben-Zvi, 1992, pp. 208-212.

Menard, P., "Les combattants en Terre Sainte au temps de Saladin et de Richard Coeur de Lion", en Paviot, J. y Verger, J. (eds.), Guerre, pouvoir et noblesse au Moyen Age: mélanges en l'honneur de Philippe Contamine, París, Presses de l'Université Paris-Sorbonne, 2000, pp. 503-511.

Meri, J.W., The Cult of the Saints among Muslims and Jews in Medieval Syria, Oxford, Oxford University Press, 2002.

Messadié, G., Saladin, chevalier de l'Islam, París, L'Archipel, 2007. 
Michaudel, B., "Le château de Saône (Sayün-Qal'at Salah al-Din) et ses défenses", Architecture Islamique, 11 (2001), pp. 201-206.

Michaudel, B., "Étude historique de Qal'at Salah al-Din (Sayun-Château de Saône)",[http:// castellorient.fr] [en línea] (2002) (consulta: 10/10/2013).

Michaudel, B., "Les organes de défense de l'enceinte ayyoubide du Caire", AI, 36 (2002), pp. 287-337.

Michaudel, B., "Les refortifications ayyoubides et mameloukes en Syrie du Nord (fin XII'début XIV siècles), en Faucherre, N., Mesqui, J. y Prouteau, N. (eds.), La fortification au temps des Croisades. Actes du Colloque International de Phartenay. (2002), Rennes, Presses Universitaires de Rennes, 2004, pp. 179-189.

Michaudel, B., Les fortifications ayyoubides et mameloukes en Syrie côtière de la fin du $X I I^{e}$ siècle au début du XIVe siècle. Tesis Doctoral, dir. Marianne Barrucand, Université Sorbonne-Paris IV, 2005.

Michaudel, B., "The Development of Islamic Military Architecture during the Ayyubid and Mamluk Reconquest of Frankish Syria”, en Kennedy, H. (ed.), Muslim Military Architecture in Greater Syria, Leiden, Brill, 2006, pp. 106-121.

Michaudel, B., "The Use of Fortification as a Political Instrument by the Ayyubids and the Mamluks in Bilad al-Sham and in Egypt (Twelfth-Thirtheenth Centuries)", MSR, 11/1 (2007), pp. 55-67.

Michaudel, B., "Aiyubidische und mamlukische Befestigungen in syrischen Küstengebeit zur Zeit der Kreuzzüge", en PIANA, M. (ed.), Burgen und Städte der Kreuzzugszeit, Petersberg, Michael Imhof Verlag, 2008, pp. 102-109.

Michaudel, B., "La poliorcétique au temps de Saladin, l'exemple de la campagne militaire de 1188 en Syrie côtiére", AI, 43 (2009), pp. 245-272.

Michaudel, B., "Medieval Fortifications under the Ayyubids and the Early Mamluks", Conférence pour l'Institut Français d'Études Anatoliennes dans le cycle "Fortifier un lieu, une ville, un territoire entre le $X^{e}$ et le XV siècle: exemples anatoliens et des villes voisines", Estambul, mayo 2009, inédito.

Micheau, F., L'Orient au temps des Croisades, présentation, traduction et notes, París, Flammarion, 2002.

Michaudel, B., "Ibn al-Athīr", en Mallet, A. (ed.) Medieval Muslim Historians and the Franks in the Levant, Leiden, Brill, 2014, pp. 52-83.

Miles, G.C., "The Ayyūbid Dynasty of Yaman and their Coinage", The Numismatic Chronicle, 19 (1939), pp. 62-97.

Milwright, M., "Pottery in Written Sources of the Ayyubid-Mamluk Period (c. 567-923/11711517), BSOAS, 62/3 (1999), pp. 504-518.

Milwright, M., "Central and Southern Jordan in the Ayyubid Period: Historical and Archaeologic Perspectives", Journal of the Royal Asiatic Society, 16/1 (2006), pp. 1-27.

Milwright, M., The Fortress of the Raven: Karak in the Middle Islamic Period (1100-1650), Leiden, Brill, 2008.

Milwright, M., "The Pottery of Ayyubid Jerusalem”, en Hillenbrand, R. y Auld, S. (eds.), Ayyubid Jerusalem: The Holy City in Context (1187-1250), Londres, Altajir Trust, 2009, pp. 408-417.

Minorsky, V., "The Prehistory of Saladin", Studies in Caucasian History, Londres, Cambridge University Press, 1953, pp. 107-157.

Miura, T., "The Sālihiya Quarter in the Suburbs of Damascus, its Formation, Structure and Transformation in the Ayyubid and Mamluk Periods", BEO, 47 (1995), pp. 129-181.

MoAz, A., "Note sur le mausolée de Saladin à Damas: son fondateur et les circonstances de sa fondation", BEO, 39 (1989), pp. 184-189. 
MöHring, H., Sultan Saladin und der Dritte Kreuzzug: Aiyubidische Strategie und Diplomatie in Vergleich vornehmlich der arabisches mit laleinischen Quellen, Tesis Doctoral, Universität Frankfurt am Main, 1977, pub. Weisbaden, Steiner, 1980.

Möhring, H., "Heiliger Krieg und politische Pragmatik: Salahadinus Tyrannus", Deutsches Archiv für Erforschung des Mittelalters, 39 (1983), pp. 417-466.

Möhring, H., "Zwischen Joseph-Legende und Mahdi-Erwartung: Erfolge und Ziele Sultan Saladins im Spiegel zeitgenossicher Dichtung und Weissagung", en en LEV, Y. (ed.), War and Society in the Eastern Mediterranean, $7^{\text {th }}-15^{\text {th }}$ Centuries, Leiden, Brill, 1997, pp. 177225.

Möhring, H., "Zwei aiyubidische Briefe an Alexander III. Und Lucius III. bei Radulf de Diceto zum Kriegsgefangenenproblem”, Archiv für Diplomatik, 46 (2000), pp. 197-216.

Möhring, H., "Saladin, der edle Heide. Mythisierung und Realität", en Gaube, H., SchneIdMÜLler, B. y Weinfurter, S. (eds.), Konfrontation der Kulturen? Saladin und die Kreuzfahrer, Maguncia, Verlag Philipp von Zabern, 2005, pp. 160-175.

Möhring, H., "Saladin und die Frage der religiösen Toleranz", en WieczoreK, A., Fansa, M. y Meller, H. (eds.), en Saladin und die Kreuzfahrer, Maguncia, Verlag Philipp von Zabern, 2005, pp. 157-162.

MöHRING, H., "Saladin und sein Hof”, ibídem, pp. 319-326.

MöHring, H., Saladin: Der Sultan und seine Zeit, 1138-1193, Munich, C.H.Beck, 2005; trad. inglesa Saladin: the Sultan and His Times, 1138-1193, Baltimore, Johns Hopkins University Press, 2008; trad. española Saladino, el sultán y su época, 1138-1193, Barcelona, Crítica, 2010.

MöHring, H., "Zengiden, Ayubiden und Mamluken. Muslimische Herrscher der Kreuzzugszeit”, en Piana, M. (ed.), Burgen und Städte der Kreuzzugszeit, Petersberg, Michael Imhof Verlag, 2008, pp. 47-60.

Monchamp, J., Contribution à l'étude de la céramique médiévale égyptienne. Chrono-typologie des céramiques issues des fouilles de la muraille ayyoubide du Caire (fin Xe - début $X V I^{e}$ siècles), Tesis Doctoral, dir. Jean-Pierre van Staëvel, Université Paris-Sorbonne IV, 2011.

Moses, P., The Saint and the Sultan: The Crusades, Islam, and Francis of Assisi's Mission of Peace, Nueva York, Doubleday, 2009.

Moussé, C., Mouton, J.M., Sourdel-Thomine, J. y Sourdel, D., "La décourverte d'un navi Zakariyya' à la grande mosquée de Damas à l'époque ayyoubide", Der Islam, 90/2 (2013), pp. 412-444.

Mouton, J.M., Damas et sa principauté sous les Saljoukides et les Bourides (468- 549/10761154), Tesis Doctoral, dir. Dominique Sourdel, Université Sorbonne-Paris IV, 1993.

Mouton, J.M., "La forteresse de l'Ile de Graye (Qal'at Ayla) à l'époque de Saladin", AI, 29 (1995), pp. 75-90.

Mouton, J.M., "La route de Saladin (Tariq Sadr wa Ayla) au Sinaï”, AI, 30 (1996), pp. 41-70.

Mouton, J.M., "La conquête de la Cyrénaïque et de la Tripolitaine par Qaraqush: initiative individuelle ou entreprise d'État ?", en Chanson-Jabeur, C., Gallet, D., Laronde, A. y Lochon, C. (eds.), Aux rivages des Syrtes: la Libye, espace et développement de l'Antiquité à nos jours, París, Centre des hautes études sur l'Afrique et l'Asie modernes, 2000, pp. 59-69.

Mouton, J.M., "Les bédouins entre Syrie et Égypte au temps des croisades" en JEHEL, G. (ed.), Orient et Occiden du IX e au XV siècle, París, Editions du Temps, 2000, pp. 293-300.

Mouton, J.M., "Signes de reconnaissance et signes de distinction chez les ulémas égyptiens de l'époque ayyoubide", en DÉCOBERT, C. (ed.), Valeur et distance, identités et societés en Egypte, París, Maisonneuve et Larose, 2000, pp. 151-161. 
Mouton, J.M., Saladin, le sultan chevalier, París, Gallimard, 2001.

Mouton, J.M., "Saladin et les bédouins du Sinaï", Cahiers des Annales Islamologiques, 21 (2001), pp. 197-206.

Mouton, J.M., "Saladin et les Pisans", en Tous Azimuts...., Mélanges de recherches en l'honneur du Professeur Georges Jehel, Histoire médiévale et archéologie, 13 (2002), pp. 345-383.

Mouton, J.M., "Vie quotidienne et société dans les forteresses ayyoubides: le cas de la forteresse de Sadr au Sinaï", $16^{\text {th }}$ Colloquium on the History of Egypt and Syria in the Fatimid, Ayyubid and Mamluk Eras (Gante, 9/11 de mayo de 2007), inédito.

Mouton, J.M., "La tente du prince et le campament des armées à l'époque ayyoubide", Turcica, 41 (2009), pp. 183-198.

Mouton, J.M., "Damas. Portes et mourailles millénaires”, Archéologia, 473 (2010), pp. 3850.

Mouton, J.M., Sadr, une forteresse de Saladin au Sinaï. Histoire et Archéologie, París, De Boccard, 2010.

Mouton, J.M., “A propos de la pauvreté à Damas à l'époque ayyoubide: deux documents inédits", Archiv für Papyrusforschung, 57/1 (2011), pp. 99-108.

Mouton, J.M., "Deux documents damascains touchant le rachat des captifs détenus par les Francs", Archiv für Papyrusforschung, 59/2 (2013), pp. 405-420.

Mouton, J.M., Sourdel, D., SOurdel-Thomine, J., Mariage et séparation à Damas au Moyen Âge. Un corpus de 62 documents juridiques inédits entre 337/948 et 698/1299, Documents relatifs à l'histoire des croisades publiés par l'Académie des Inscriptions et Belle-Lettres, 21, Paris, 2013.

Mouton, J.M., Sourdel, D., Sourdel-Thomine, J. y Dayoub, B., “Témoignages epigraphiques damascains sur un sayh méconnu d'époque ayyoubide”, Der Islam, 87/1 (2012), pp. 185203.

Mouton, J.M., Moussé, C., Sourdel-Thomine, J. y Sourdel, D., "La décourverte d'un navi Zakariyya' à la grande mosquée de Damas à l'époque ayyoubide", Der Islam, 90/2 (2013), pp. 412-444.

MÜLler-WIENER, M., "Science and the Handmaiden of Power: Science, Art and Technology in Ayyubid Syria", en Hillenbrand, R. y Auld, S. (eds.), Ayyubid Jerusalem: The Holy City in Context (1187-1250), Londres, Altajir Trust, 2009, pp. 418- 422.

Munir, F.Z., "Sultan al-Malik Muhammad al-Kamil and Saint Francis: Interreligious Dialogue and the Meeting at Damietta", Journal of Islamic Law and Culture, 10/3 (2008), pp. 305-314.

Nehmé, A., "Salah al-Din et la noblesse féminine des États latins d'Orient: des relations de paix", en Prouteau, N. y Senac, P. (eds.), Chrétiens et musulmans en Méditerranée médiévale (VIII ${ }^{e}$-XIII ${ }^{e}$ siècle). Echanges et contacts, Poitiers, Université de Poitiers, 2003, pp. 109-114.

Neocleus, S., "The Bizantines and Saladin: Some Further Arguments”, AM, 25/2 (2013), pp. 204-221.

Nicolle, D., The Military Technology of Classical Islam, Tesis Doctoral, dir. Robert Hillenbrand, University of Edinburgh, 1983.

Nicolle, D., Saladin and the Saracens, Oxford, Osprey Publishing, 1986 (Men-at-Arms, 171).

Nicolle, D., Hattin 1187. Saladin's Greatest Victory, Oxford, Osprey Publishing, 1993 (Campaign, 19); trad. Hattin, 1187, Madrid, Ediciones del Prado, 1999.

NicolLE, D., "Wounds, Military Surgery and the Reality of Crusading Warfare; the Evidence of Usamha's Memories", Journal of Oriental and African Studies, 5 (1993), pp. 33-46. 
Nicolle, D., Medieval Warfare Source Book: Christian Europe and its Neighbours (Vol. II), Londres, Brockhampton Press, 1996.

Nicolle, D., Arms and Armour of the Crusading Era, 1050-1350: Islam, Eastern Europe and Asia (Vol. II), Londres, Greenhill Books, 1999.

Nicolle, D., "The Manufacture and Importation of Military Equipment in the Islamic Eastern Mediterranean, $10^{\text {th }}$ to $14^{\text {th }}$ Centuries", en ES III, pp. 139-162.

Nicolle, D., Warriors and Their Weapons Around the Time of Crusades: Relationships between Byzantium, the West and the Islamic World Burlington, Aldershot, 2002.

Nicolle, D., The Third Crusade 1191, Richard the Lionheart, Saladin and the Struggle for Jerusalem, Oxford, Osprey Publishing, 2005 (Campaign, 161); trad. La batalla por Jerusalén, Barcelona, RBA, 2011.

Nicolle, D., Fighting for the Faith: The Many Fronts of Medieval Crusade and Jihad, 10001500 AD., Barnsley, Pen \& Sword Military, 2007.

Nicolle, D., Saracen Strongholds 1100-1500, Oxford, Osprey Publishing, 2009 (Fortress, 87).

Nicolle, D., Saladin, Oxford, Osprey Publishing, 2011(Command, 12).

Nielsen, J., "The Participation of Christians and Jews in the Ayyubid and Mamluk State: A Historiographical Reflection", en HADDAD, M. (ed.), Towards a Cultural History of the Mamluk Era, Beirut, Orient Institut Beirut, 2010, pp. 3-7.

Nierman, J.H., Aimery II of Jerusalem and His Relations with His Ayyubid Neighbors, Tesis Doctoral, New York University, 1971.

Nierman, J.H., "Levantine Peace following the Third Crusade: A New Dimension in FrankishMuslim Relations", The Muslim World, 65/2 (1975), pp. 107-118.

Northrup, L., "The Bahri Mamluk Sultanate, 1250-1390", en Petry, C.F. (ed.), The Cambridge History of Egypt, 2 vols., Cambridge, Cambridge University Press, 1998, vol. I, pp. 242-289.

Nuссіотті, M., “Analisi stratigrafiche degli elevati a Shawbak: primi risultati”, en VANNINI, G.(ed.), rcheologia dell'insediamento crociato-ayyubide in Transgiordania: il Progetto Shawbak, Florencia, Edizioni All'Insegna del Giglio, 2007, pp. 29-57

Nucciotti, M., "Shawbak and South Transjordan in the Ayyubid Epoch", en VAnNini, G. y Nucciotti, M. (eds.), From Petra to Shawbak, Archeology of a Frontier, Florencia, Giunti Editore, 2009, pp. 110-125.

Nucciotтi, M., "Il palazzo Ayyubide di Shawak, analisi archeologica e contestualizzazione storica", en Changes and Challenges - 11th International Conference on the History and Archeology of Jordan, París, 7-14 de junio 2010, inédito.

Онтолнi, T., "The Manners, Customs and Mentality of Pilgrims to the Egyptian City of the Dead: 1100-1500 A.D.", Orient, 29 (1993), pp. 19-44.

O'Kane, B., "The Ayyubids and Early Mamluks (969-1171) [sic; read: 1171-1382]", en The Treasures of Islamic Art in the Museums of Cairo, El Cairo y Nueva York, The American University in Cairo Press, 2006, pp. 92-161.

O'Kane, B., "Ayyubid Architecture in Cairo", en Hillenbrand, R. y Auld, S. (eds.), Ayyubid Jerusalem: The Holy City in Context, 1187-1250, Londres, Altajir Trust, 2009, pp. 423434.

O'Kane, B., “The Ayyubids and Early Mamluks”, en SEROUR, A. (ed.), Writing Egypt: History, Literature and Culture, El Cairo, The American University in Cairo Press, 2012, pp. 199-207.

Pahlitzsch, J., "The Transformation of Latin Religious Institutions into Islamic Endowments by Saladin in Jerusalem", en Pahlitzsch, J. y Korn, L. (eds.), Governing the Holy City: The 
Interaction of Social Groups in Medieval Jerusalem, Wiesbaden, Reichert Verlag, 2004, pp. 47-69.

Paine, L., Saladin, A Man For All Ages, Londres, Hale, 1974.

Pellat, C., "Un traité de hisba signé: Saladin”, en Traini, R. (ed.), Studi in onore di Francesco Gabrieli nel suo ottantesimo compleanno, 2 vols., Roma, Università di Roma La Sapienza, Dipartimento di studi orientali, 1984, vol. II, pp. 593-598.

Petersen, A.D., "Two Medieval Castles and Their Position in the Military Architecture of Muslim Palestine", en ES III, pp. 383-406.

Philipps, J.P., "The Travels of Ibn Jubayr and His View of Saladin", en Villads Jensen, K. (ed.), Cultural Encounters during the Crusades, Odense, University Press of Southern Denmark, 2013, pp. 75-90.

PoliaK, A., "The Ayyubid Feudalism", Journal of the Royal Asiatic Society, 71/3 (1939), pp. 428-432.

Pouzet, L., "Maghrébins à Damas au VII'/XIII siècle", BEO, 28 (1975), pp. 167-199.

Pouzet, L., "Deux grammairiens à Damas au VII/ $/ \mathrm{XIII}$ e siècle", Mélanges de l'Université Saint-Joseph, 49 (1975-1976), pp. 767-784.

PouZet, L., "La descendance de l'historien 'Alī Ibn 'Asākir et ses alliances à Damas au VII'/ XIII siècle”, Mélanges de l'Université Saint-Joseph, 50, 1984, pp. 515-529.

Pouzet, L., "Abū Shāma (599-665/1203-1268) et la societé damascaine de son temps", BEO, 37-38 (1985/1986), pp. 115-126.

PouZET, L., "L'année des Khawārezmiens: 643/1245-46. Essai d'analyse historique d'un texte d'ad-Dahabī (m. 748/1348)", Atti del XIII congresso dell'UEAI (Venise 29 septembre-4 octobre 1986), Quaderni di Studi Arabi, 5-6 (1987-1988), pp. 679-689.

PouZet, L., Damas au VII'/XIII siècle: vie et structures religieuses d'une métropole islamique, Beirut, Dar el-Mahreq, 1988.

PouZET, L., "Les madrasas et leur professeurs au VII'-XIII siècle", Mélanges de l'Université Saint-Joseph, 52 (1991-1992), pp. 121-196.

Pouzet, L., "Vision populaire de la femme en Syrie aux VI et VII $/ \mathrm{XII}{ }^{\circ}$ et XIII ${ }^{\mathrm{e}}$ siècles" en Fodor, A. (ed.), Proceedings of the 14th Congress of the UEAI (Budapest, 1988), 2 vols., Budapest, 1995, part. I, pp. 295-304.

PouZet, L., "Deux figures controversées du mysticisme à Damas au Moyen Âge: 'Alī alHarīīi (m. 645/1244) et Ibn Isrā'̄il (m. en 677/1278)", in Proceedings of the 20th Congress of the Union Européenne des Arabisants et Islamisants, 2 vols., Budapest, 2003, part. II, pp. 61-69.

PowERs, J.M., "Saint Francis and the Sultan: the Curious History of a Christian-Muslim Encounter", Religion, 41/3 (2011), pp. 496-499.

PozzA, M., I trattati con Alepo, 1207-1254, Venecia, Il Cardo, 1990.

Pradines, S., "L'enceinte urbaine du Caire ayyoubide: résultats préliminaires de la mission 1999", Archéologie Islamique, 11 (2001), pp. 195-200.

Pradines, S., "La muraille de Saladin au Caire", L'Archéologue, 64 (2003), pp. 30-31.

Pradines, S., "Saladin, le bâtisseur", Histoire Antique et Médiévale, 25 (2010), pp. 50-57.

Pradines, S., "Burg al-Zafar, une architecture de passage, des Fatimides aux Ayyoubides", $21^{s t}$ Colloquium on the History of Egypt and Syria in the Fatimid, Ayyubid and Mamluk Eras (Gante, 9/11 de mayo de 2012), inédito.

Pringle, D., "The Castles of Ayla (al-'Aqaba) in the Crusader, Ayyubid and Mamluk Period", en ESIV, pp. 333-354.

QARATĀy Al-'IzZī, Ta' rīhh, trad. italiana de G. Levi, "L'invasione dei Tartari in Siria nel 1260 nei ricordi di un testimone oculare", Orientalia, 1935, p. 353-376. 
RaBIE, H.M., "The Size and Value of the iqta in Egypt, 564-741 A.H. /1169-1341 A.D.", en Coor, M.A. (ed.), Studies in the Economic History of the Middle East: from the Rise of Islam to the Present Day, Londres, Psychology Press, 1970, pp. 129-138.

RabIE, H.M., The Financial System of Egypt (1169-1341), Londres, Oxford University Press, 1972.

RAFEQ, A., "Damas et Alep, métropoles commerciales des Ayyoubids aux Ottomans", en CluZAN, S., (ed.), Syrie, memoire et civilisation, París, Flammarion, 1993, pp. 396-401.

RAGIB, Y., "Morts dans la ville. Les sépultures de Fustat et du Caire jusqu'à la fin des Ayyoubides", AI, 46 (2012), pp. 337-386.

Raphael, S.K., The Muslim Concept of Defense in Greater Syria in the Late $12^{\text {th }}$ and $13^{\text {th }}$ Centuries in the Light of Historical, Archaeological and Architectural Analysis of Ayyubid and Early Mamluk Fortifications, Tesis Doctoral, dirs. Reuven Amtai y Ronnie Ellenblum, The Hebrew University of Jerusalem, 2008.

RaphaEl, S.K., "Ayyubid Fortresses in the Late Twelfth and Early Thirteenth Centuries", en Raphael, S.K., Muslim Fortresses in the Levant, Between Crusaders and Mongols, Londres, Routledge, 2010, pp. 4-51.

RAPHAEL, S.K., "Mighty Towers and Feeble Walls: Ayyubid and Mamluk Fortifications in the Late Twelfth and Early Thirteenth Centuries in the Light of the Decline of Crusader Siege Warfare", Crusades, 9 (2010), pp. 147-158.

Recueil des Historiens des Croisades. Historiens Orientaux, 5 vols., París, Académie des Inscriptions et Belles-Lettres, 1872-1906.

Regan, G., Saladin and the Fall of Jerusalem, Londres, Routledge, 1987.

RAPHAEL, S.K., Lionhearts: Saladin and Richard I, Londres, Constable, 1988.

Regourd, A., "Trade on the Red Sea during the Ayyubid and Mamluk Periods. The Quseir Paper Manuscript Collection 1999-2003, First Data", Proceedings of the Seminar for Arabian Studies, 34 (2004), pp. 277-292.

ReInaud, J.L., Notice sur la vie de Saladin, sultan d'Egypte et de Syrie, París, Dondey- Dupré, 1824.

ReINFAndt, L., "Recycled Documents in Textiles from Ayyubid and Mamluk Egypt", $21^{s t}$ Colloquium on the History of Egypt and Syria in the Fatimid, Ayyubid and Mamluk Eras (Gante, 9-11 de mayo de 2012), inédito.

Richard, J., "La Chanson de Syracon et la légende de Saladin”, Journal Asiatique, (1949), pp. 155-158.

Richard, J., "An Account of the Battle of Hattin Referring to the Frankish Mercenaries in Oriental Muslem States", Speculum, 27/2 (1952), pp. 168-177.

Richard, J., "Les prisonniers et leur rachat au cours des croisades", en Dufour, J. y Platelle, H. (eds.), Fondations et oeuvres charitables au Moyen Âge, París, Éditions du CTHS, 1999, pp. 63-73.

RichARD, J., "Les transformations de l'image de Saladin dans les sources occidentales", Revue des mondes musulmans et de la Méditerranée, 89 (2000), pp. 177-187.

Richards, D.S., “The Early History of Saladin”, Islamic Quarterly, 17 (1973), pp.140-159.

Richards, D.S., “A Consideration of Two Sources for the Life of Saladin”, Journal of Semitic Studies, 25 (1980), pp. 46-65.

Richards, D.S., “A Petition for an iqta adressed to Saladin or al-'Adil”, BSOAS, 55/1 (1992), pp. 98-105.

Richards, D.S., "Imād al-Dīn al-Isfahāni: Administrator, Littérateur and Historian”, en SHATZMiLler, M. (ed.), Crusaders and Muslims in Twelfth Century Syria, Leiden, Brill, 1993, pp. 133-146. 
Richards, D.S., "Saladin's Hospital in Jerusalem: Its Foundation and Some Later Archival Material", en Atнamina, K. y Heacocк, R. (eds.), The Frankish Wars and their Influence in Palestine, Birzeit, Birzeit University Publications, 1994, pp. 70-83.

Richards, D.S., "More on the Death of the Ayyubid Sultan al-Salih Najm al-Din Ayyub", en Bahm- Harding, Ç. e ImBer, C. (eds.), The Balance of Truth: Essays in Honour of Professor Geoffrey Lewis, Estambul, The Isis Press, 2000, pp. 269-274.

Richards, D.S., "Biographies of Ayyubid Sultans", en Hillenbrand, R. y Auld, S. (eds.), Ayyubid Jerusalem: The Holy City in Context 1187-1250, Londres, Altajir Trust, 2009, pp. 441-455.

Richards, D.S., "Ibn Wāsil, Historian of the Ayyubids”, ibídem, pp. 456-459.

Richards, D.S., "Ramla in the Ayyubid and Mamluk Periods",en PRINGLE, D. y PETERSEN, A. (eds.), Ramla: A City of Muslim Palestine, AD.c. 715/1917: Studies in History, Architecture and Archaeology, Oxford, British Academy Monographs in Archaeology, en preparación.

Richter-Bernburg,L., Der syrische Blitz. Saladins Sekretär zwischen Selbstdarstellung und Geschichtsschreibung, Stuttgart, Franz Steiner Verlag, 1998.

Richter-Bernburg,L., "Past Glory and Present Ignorance: Abd al-Atif al-Baghdadi on Ayyubid Egypt", en ES V, pp. 349-367.

Richter-Bernburg,L., "Contemporary Perspectives on Fatimid and Ayyubid Building and Engineering", $16^{\text {th }}$ Colloquium on the History of Egypt and Syria in the Fatimid, Ayyubid and Mamluk Eras (Gante, 9/11 de mayo de 2007), inédito.

Richter-Bernburg,L., “'Imād al-Dīn al-Ișfahānī”, en Mallet, A. (ed.), Medieval Muslim Historians and the Franks in the Levant, Leiden, Brill, 2014, pp. 29-51.

Rikabi, J., La Poésie profane sous les Ayyûbides et ses principaux représentants, París, G.P. Maisonneuve, 1949.

RiPKE, M., Saladin und sein Biograph Baha'addin b. Saddad, Tesis Doctoral, Universität Bonn, 1988.

RizwAn, A.S., Izz al-Din al-Sulami. His Life and Works, Islamabad, Islamic Research Institute, 1978.

Robinson, CH.F., Islamic Historiography, Cambridge, Cambridge University Press, 2003.

Rosen-Ayalon, M., "Art and Architecture in Ayyubid Jerusalem”, Israel Exploration Journal, 40/4 (1990), pp. 305-314.

Rosen-Ayalon, M., "Between Cairo and Damascus: Rural Life and Urban Economics in the Holy Land during the Ayyubid, Mamluk and Ottoman Periods", en Levy T.E. (ed.), The Archaeology of Society in the Holy Land, Nueva York, Continuum, 1998, pp. 512-523.

Rosenthal, F., A History of Muslim Historiography, Leiden, Brill, 1952.

Rouxel, A., La place de Jerusalem dans l'idéologie de Saladin, Tesis Doctoral, dir. John Tolan, Université de Nantes, 1998.

Rusell, J.C., "The Population of Medieval Egypt", Journal of the American Research Center in Egypt, 5 (1966), pp. 69-82.

Salamah, S.A., Medina in the Ayyubid Period and the Shi'a Influence upon it, Tesis Doctoral, dir. Ian Richard Netton, University of Leeds, 2008.

SAlih'ABD Al-MaliK, S., "Deux hammams ayyoubides dans le Sinaï: étude archéologique et architecturale", en Boussac, M.F., Fournet, T y Redon, B. (eds.), Le bain collectif en Égypte, El Cairo, Institut Français d'Archéologie Orientale, 2009, pp. 305-311.

SAunier, A., "Saladin et l'Hôpital de Saint-Jean d'Acre dans le récit du Ménestrel de Reims, ou le regard d'un Oriental sur une institution occidentale" en Tous Azimuts...., Mélanges de recherches en l'honneur du Professeur Georges Jehel, Histoire médiévale et archéologie, 13 (2002), pp. 423-433. 
SAuvaget, J., "Le cénotaphe de Saladin”, Revue des arts asiatiques, 6/3 (1930), pp. 168- 175.

Sauvaget, J., Alep, essai sur le développement d'une grande ville syrienne, des origines au milieu du XIX $X^{e}$ siècle, París, P. Geuthner, 1941.

Sauvaget, J. (ed.), Les monuments ayyoubides de Damas, 4 vols., París, E. de Boccard, 19401950.

Al-SAwwĀs,M., Al-SāGirgī, M. y Leder, S., Mu'ğam al-sammā 'āt al-dimašqūyat 550-750 h. Les certificats d'audition à Damas: 1155-1349, Damasco, IFEAD, 1996.

Al-Sawwās,M., Al-SāGirgī, M. y Leder, S., Mu'ğam al-samā'āt al-Dimašqiyya. Șuwar al mahtututât al-muntahabat min sanat 550 ilā 750 h. / 1155 ilā 1349 h. Recueil de documents: fac-similés des certificats d'audition à Damas 550 - 750h. / 1135 - 1344, Damasco, IFEAD, 2000.

Sватн, P., Choix de livres qui se trouvaient dans les bibliothèques d'Alep (au XIII' siècle), El Cairo, Institut Français d'Archéologie Orientale, 1946.

Schaefer, K.R., Jerusalem in the Ayyubid and Mamluk Eras, Tesis Doctoral, New York University, 1985.

Schultz, W.C., "Ayyubid and Mamluk Coins Preserved in the Oriental Institute of the University of Chicago", Journal of Near Eastern Studies, 60/4 (2001), pp. 269-273.

ScotT, W., The Talisman, Londres, Archibald Constable, 1825.

SEll, E., The Ayyub and Mamluk Sultans, Londres, Church Missionary Society, 1929.

Shaddoud, I., Céramiques des forteresses croisées, ismaïliennes, ayyoubides et mameloukes de Syrie du Nord, Tesis Doctoral, dir. Veronique Francois, Université Aix-Marseille, 2014.

Shaik, Z., Ayyubid Aleppo (1178-1260), Ontario, E. Keall, 2008.

Sharon, M., "The Ayyubid Walls of Jerusalem. A New Inscription from the Time of alMu'azzam Isa", en Rosen-Ayalon, M. (ed.), Studies in Memory of Gaston Wiet, Jerusalén, The Hebrew University Magnes Press, 1977, pp. 179-193.

Sharon, M., Corpus Inscriptionum Arabicarum Palaestinae, Leiden, Brill, 1997-2008.

Sharon, M., "Two Inscriptions of the Time of al-Mu'azzam Isa”, Jerusalem Studies in Arabic and Islam, 24 (2000), pp. 508-518.

Shatzmiller, M., "The Crusades and Islamic Warfare, a Re-evaluation", Der Islam, 69/2 (1992), pp. 247-288.

SibṬ IBn Al-ŶAwZī, Mir'āt al-Zamān fì Ta'rīj al-A 'yān, trad. francesa de S. Sayde-Hajjar, Mir'āt al-Zamān fi Ta'rikh al-A 'yān, traduction annotée (589-1193 à 654-1256), Tesis Doctoral, dir. Claude Cahen, Université Sorbonne-Paris I, 1982; trad. francesa de F. Monot, L'Orient islamique au VI ${ }^{e}$-XII ${ }^{e}$ siècles à travers le "Mir'ät al-Zamān fi Ta'rikh al-A 'yān", traduction annotée sur les annés 518-569/1124-1175, Tesis Doctoral, dir. Dominique Sourdel, Université Sorbonne-Paris IV, 1992.

Sidarus, A., "Families of Coptic Dignitaries (buyūtāt) under the Ayyūbids and the Golden Age of Coptic Arabic Literature (13th cent.)", Journal of Coptic Studies, 15 (2013), pp. 189-208.

SINGER, L., The Minbar of Saladin: Reconstructing a Jewel of Islamic Art, Nueva York, ThAmEs \& Hudson, 2008.

SivAn, E., "Le caractère sacré de Jerusalem dans l'Islam aux XII'-XIII' siècles", Studia Islamica, 7 (1967), pp. 149-182.

Sivan, E., "Notes sur la situation des chrétiens à l'époque ayyoubide", Revue de l'histoire des religions, 172/2 (1967), pp. 117-130.

Sivan, E., "Réfugiés syro-palestiniens au temps des croisades", REI, 35 (1967), pp. 135-147.

Sivan, E., L'Islam et la croisade, idéologie et propagande dans les reactions musulmans aux Croisades, París, Adrien Maisonneuve, 1968.

Sivan, E., "Saladin et le calife al-Nasir", Scripta Hierosolymitana, 23 (1972), pp. 126-145. 
Smith, G.R., "The Ayyubids and Rasulids: The Transfer of Power in $7^{\text {th }} / 13^{\text {th }}$ Century Yemen, Islamic Culture, 43 (1969), pp. 175-188.

Sмith, G.R., The Ayyubids and the Early Rasulids in the Yemen (567-694/1173-1295). A Study of Ibn Hatim 's "Kitab al-Simt”, 2 vols., Londres, The Trustees of the E.J.W. Gibb Memorial, 1978.

Smith, G.R., Studies in the Medieval History of the Yemen and South Arabia, Aldershot, Ashgate, 1997.

Smoor, P., "Umãra's Poetical Views of Shãwar, Dirghãm, Shĩrkũh and Salãh al-Dĩn as Viziers of the Fatimid Caliphs", en Daftary, F. y Meri, J.W. (eds.), Culture and Memory in Medieval Islam. Essays in Honour of Wilferd Madelung, Londres-Nueva York, I.B. Tauris, 2003, pp. 410-432.

SoEtens, S., "Sagarat al-Durr: A Comparative Study of Three Historical Sources", Orientalia Lovaniensia Periodica, 30 (1999), pp. 97-112.

Sourdel, D., "Les professeurs de madrasa à Alep aux XII ${ }^{\mathrm{e}}-\mathrm{XIII}{ }^{\mathrm{e}}$ siècles d'après Ibn Shaddad", $B E O, 13$ (1949-1951), pp. 85-115.

Sourdel, D., "Rūhīn, lieu de pèlerinage musulman de la Syrie du nord au XIII' siècle", Syria, 30 (1953), pp. 89-107.

Sourdel, D., "Réflexions sur la diffusion de la madrasa en orient du $\mathrm{XI}^{\mathrm{e}}$ au XIII" siècle", $R E I$, Hors série 13 (1976), pp. 165-184.

Sourdel, D., "Nouvelle lettre d'un docteur hanbalite de Damas à l'époque ayyoubide", Journal of Near Eastern Studies, 40/4 (1981), pp. 265-276.

Sourdel, D. y Sourdel-Thomine, J., "Nouveaux documents sur l'histoire religieuse et sociale de Damas au moyen-âge", REI, 32 (1964), pp. 1-15.

Sourdel, D. y Sourdel-Thomine, J., "Un texte d'invocations en faveur de deux princes Ayyūbides", en Koouymuan, D.K., (ed.), Near Eastern Numismatics, Iconography, Epigraphy and History: Studies in honor of George C. Miles, Beirut, American University of Beirut, 1974, pp. 347-352.

Sourdel, D. y Sourdel-Thomine, J., Certificats de pèlerinage d'époque ayyoubide: contribution à l'histoire de l'idéologie de l'Islam au temps des croisades, Paris, Académie des Inscriptions et Belles-Lettres, 2006.

Sourdel, D., Sourdel-Thomine, J. y Mouton, J.M., Mariage et séparation à Damas au Moyen Âge. Un corpus de 62 documents juridiques inédits entre 337/948 et 698/1299, Documents relatifs à l'histoire des croisades publiés par l'Académie des Inscriptions et Belle-Lettres, 21, Paris, 2013.

Sourdel, D., Sourdel-Thomine, J., Mouton, J.M. y Dayoub, B., “Témoignages epigraphiques damascains sur un sayh méconnu d'époque ayyoubide", Der Islam, 87/1 (2012), pp. 185 203.

Sourdel-Thomine, J., "Les anciens lieux de pèlerinage damascains d'après les sources arabes", $B E O, 14$ (1952-1954), pp. 65-85.

Sourdel-Thomine, J., "Le peuplement de la région des «villes mortes» (Syrie du nord) à l'époque ayyoubide", Arabica, 1 (1954), pp. 187-199.

Sourdel-Thomine, J., Al-Harawi, Guide des lieux de pèlerinage, Damasco, Institut Français de Damas, 1957.

Sourdel-Thomine, J., "Les conseils du Sayh al-Harawi à un prince ayyubide (édition et traduction du Kitab at-tadkira al-harawiyya fi 1-hiyal al-harbiyya", BEO, 17 (1961-1962), pp. 205-266.

Sourdel-Thomine, J., "L'état ayyoubide vu par un homme de réligion de cette époque", Israel Oriental Studies, 10 (1980), pp. 124-131. 
Sourdel-Thomine, J., "Le chaykh 'Ali al-Harawi et la propagande politico-religieuse dans la Syrie de XIII' siècle", en Makdisi, G., Sourdel, D. y Sourdel-Thomine, J., (eds.), Predication et propaganda au Moyen Âge, Islam, Byzance, Occident, París, PUF, 1983, pp. 241-56.

Sourdel-Thomine, J., "Un modèle exceptionnel parmi les certificats de pèlerinage ayyoubides", en Déroche, F. y Richard, F. (eds.), Scripts, page settings and bindings of MiddleEastern manuscripts: Papers/ The Third International Conference on Codicology and Paleography of Middle-Eastern Manuscripts (Bologna, 4-6 October, 2000), San Petesburgo, Thesa, 2003, pp. 63-68.

Sourdel-Thomine, J., Sourdel, D. y Mouton, J.M., Mariage et séparation à Damas au Moyen Âge. Un corpus de 62 documents juridiques inédits entre 337/948 et 698/1299, Documents relatifs à l'histoire des croisades publiés par l'Académie des Inscriptions et Belle-Lettres, 21, Paris, 2013.

Sourdel-Thomine, J.; Sourdel, D.; Mouton, J.M. y Moussé, C., “La décourverte d'un navi Zakariyya' à la grande mosquée de Damas à l'époque ayyoubide”, Der Islam, 90/2 (2013), pp. 412-444.

Staffa, S.J., Conquest and Fusion: The Social Evolution of Cairo, A.D. 642-1850, Leiden, E. J. Brill, 1977.

SteIner, M., "Tell Abu Sarbut: The Occupation of a Rural Site in Ayyubid/Mamluk Periods", en Steiner, M. y Van Der Steen, E.J. (eds.), Sacred and Sweet: Studies on the Material Culture of Tell Deir'Allah and Tell Abu Sarbut, Leiden, Uitgeverij Peeters, 2008, pp. 157197.

Stern, S.M., "Petitions from the Ayyubid Period", BSOAS, $27 / 1$ (1964), pp. 1-32.

Stern, S.M., "Two Ayyubid Decrees from Sinai", en STERN, S.M. (ed.), Documents from Islamic Chanceries, Cambridge, Harvard University Press, 1965, pp. 11-25.

TABBAA, Y., The Architectural Patronage of Nur al-Din, 1146-1174, Tesis Doctoral, Institute of Fine Arts of New York University, 1983.

TabBaA, Y., "Circles of Power: Palace, Citadel, and City in Ayyubid Aleppo", Ars Orientalis, 23 (1993), pp. 181-200.

Tabban, Y., Constructions of Power and Piety in Medieval Aleppo, Filadelfia, Pennsylvania University Press, 1997.

TabBAa, Y., "Dayfa Khatun: Regent Queen and Architectural Patron", en RugGles, D.F. (ed.), Women, Patronage and Self-Representation, Nueva York, State University of New York Press, 2000, pp. 17-34.

TAвbAA, Y., "Defending Ayyubid Aleppo: The Fortifications of al-Zahir Ghazi (1186-1216)", en Kennedy, H. (dir.), Muslim Military Architecture in Greater Syria, Leiden, Brill, 2006, pp. 176-183.

TABBAA, Y., "An Image of What Once Was: The Ayyubid Fortifications of Jerusalem", en HiLlenbrand, R.y Auld, S. (eds.), Ayyubid Jerusalem: The Holy City in Context, 1187-1250, Londres, Altajir Trust, 2009, pp. 460-468.

TAKAYAMA, H., "Frederick II's Crusade: an Example of Christian-Muslim Diplomacy", Mediterranean Historical Review, 25/2 (2010), pp. 169-185.

Talmon-Heller, D., Society and Religion in Syria from the Reign of Nur al-Din to the Mamluk Occupation (1154-1260), Tesis Doctoral, The Hebrew University of Jerusalem, 1999.

Talmon-Heller, D., "Religion in the Public Sphere: Rulers, Scholars and Commoners in Zangid and Ayyubid Syria (1150-1260)", en Hoexter, M. (ed.), The Public Sphere in Muslim Societies, Albany, Suny, 2002, pp. 49-64.

Talmon-Heller, D., "Fidelity, Conformity and Cohesion within Madhhabs in Zangid and Ayyubid Syria”, en Bearman, P., Peters, R. y Vogel, F. (eds.), The Islamic School of Law: 
Evolution, Devolution and Progress, Cambridge, Harvard University Press, 2005, pp. 94116.

Talmon-Heller, D., Islamic Piety in Medieval Syria. Mosques, Cemeteries and Sermons under the Zangids and the Ayyubids (1146-1260), Leiden, Brill, 2007.

Talmon-Heller, D., "Islamic Preaching in Syria during the Counter-Crusade (Twelfth-Thirteenth Centuries)", en Shagrir, I., Ellenblum, R. y Riley-Smith, J. (eds.), In Laudem Hierosolymitani: Studies in Crusade and Medieval Culture in Honour of Benjamin Z. Kedar, Aldershot, Ashgate, 2007, pp. 61-76.

Talmon-Heller, D., "Ilm, Shafa'ah and Barakah: The Resources of Ayyubid and Early Mamluk Ulama", MSR, 13/2 (2009), pp. 1-23.

TAмi, A., L'art de la guerre au temps des croisades (491/1098 - 589/1193): Du théocentrisme irrationnel aux influences mutuelles et adaptations pragmatiques dans le domaine militaire, Tesis Doctoral, dirs. Sobhi Boustani y Samaha Koury, Université Bordeaux Montaigne, 2012.

TAVERANI, C., Caravanséraits et réseaux routiers du Bilad al-Sam (fin du XII siècle-début du $X V I^{e}$ siècle), Tesis Doctoral, dir. Jean-Pierre van Stäevel, Université Sorbonne-Paris IV, 2011.

Taylor-Slaughter, G.E., Saladin, 1138-1193: A Biography, Nueva York, Exposition Press, 1955.

Thorau, P., "Die Ritterorden im Kampf mit Ayyubiden und Mamluken”, Die Welt des Orients, 31 (2001), pp. 145-164.

Thorau, P., "Shadschar ad-Durr, Sultanin von Ägypten", en WieczoreK, A., FAnsa, M. y MeLler, H. (eds.), en Saladin und die Kreuzfahrer, Maguncia, Verlag Philipp von Zabern, 2005, pp. 167-170.

TolAn, J., "Mirror of Chivalry: Saladin in the Medieval European Imagination", Cairo Papers on Social Science, 19 (1996), pp. 7-38.

Tolan, J., Le Saint chez le Sultan: la recontre de François d'Assise et de l'Islam: huit siècles d'interprétation, París, Seuil, 2007.

Tolan, J., "The Friar and the Sultan: Francis of Assisi's Mission to Egypt", European Review, 16/1 (2008), pp. 115-126.

Tramontana, F., "Khubz as Iqta in Four Autors from the Ayyubid and Early Mamluk Periods", MSR, 16 (2012), pp. 103-122.

Trotter, D.A., "The Legend of Saladin in Western Literature and Historiography", Medium Aevum, 71/1 (2002), pp. 129-130.

Tsugitaka, S., State and Rural Society in Medieval Islam, Leiden, Brill, 1997.

Turk, A., "Le rôle de la Marine ayyoubide dans le conflict Arabo-Croisades d'après les chroniques arabes (1159-1195), en AlBerini, P. (ed.), Aspetti ed attualità del potere marittimo in Mediterraneo nei secoli XII-XVI: acta del Convegno di storia militare tenuto a Napoli, in Castel dell'Ovo, dal 27 al 29 ottobre 1997, Roma, Ufficio storico della marina militare, 1999, pp. 245-256.

Usāma Ibn MunQID, Kitāb al-i 'tibār, trad. francesa de H. Derenbourg, Ousama ibn Munqidh, un emir syrien au premier siècle des Croisades (1095-1188), Paris, Leroux, 1889; trad. inglesa de P.K. Hitti, An Arab-Syrian Gentleman and warrior in the Period of the Crusades, Memoirs of Usāmah Ibn-Munqidh, Nueva York, Columbia University Press, 1929, reed. 2000; trad. alemana de G. Rotter, Usâma ibn Munqidh. Ein Leben im Kampf gegen Kreuzritterheere, Tubinga, Horst Erdmann, 1978; trad. francesa de A. Miquel, Des enseignements de la vie. Souvenirs d'un gentilhomme syrien du temps des Croisades, Paris, Imprimerie Nationale, 1983; trad. española de A. García Algarra, Libro de las experiencias, 
Madrid, Gredos, 2000; trad. inglesa de P. Cobb, The Book of Contemplation: Islam and the Crusades, Londres, Penguin Classics, 2008.

Van Ostaeyen, P., "Saladin and the Assassins: Myth versus Reality", en $9^{\text {th }}$ Colloquium on the History of Egypt and Syria in the Fatimid, Ayyubid and Mamluk Eras (Lovaina 11/12 de mayo de 2000), inédito.

Van Rentherghem, V., "La réaction des pays d'Islam face aux Croisades et aux États latins, fin du XI'-milieu du XIII" siècle", Cahiers d'Histore, 78 (2000), pp. 37-59.

WAlker, B., "Militarization to Nomadization: The Middle and Late Islamic Periods", Near Eastern Archaeology, 62/4 (1999), pp. 202-232.

WALMSLEY, A., "Fatimid, Ayyubid and Mamluk Jordan and the Crusader Interlude", en MacDonald, B., Adams, R. y Bienkowski, P. (eds.), The Archaeology of Jordan, Sheffield, Sheffield Academic Press, 2001, pp. 515-559.

Warner, N., "The Fatimid and Ayyubid Eastern Walls of Cairo: Missing Fragments", AI, 33 (1999), pp. 238-296.

Weinfurter, S., "Saladin und die Kreuzfahrer: Begegnung oder Konfrontation der Kulturen?", en Gaube, H., Schneidmüller, B. y Weinfurter, S. (eds.), Konfrontation der Kulturen? Saladin und die Kreuzfahrer, Maguncia, Verlag Philipp von Zabern, 2005, pp. 9-19.

Weksler-Bdolah, S., DA'Adli, T. y Kedar, B.Z., "La Madrasa Afdaliyya/Maqam alShaykh'id: un exemple de l'architecture ayyoubide à Jerusalem", Revue Biblique, 119/2 (2012), pp. 271-287.

Werthmuler, K.J., Coptic Identity and Ayyubid Politics in Egypt, 1218-1250, El Cairo, American University of Cairo Press, 2010.

WIET, G., "Les inscriptions de Saladin”, Syria, 3 (1922), pp. 307-328.

WIET, G., "Une inscription de Malik Zahir Ghazi à Latakieh", Bulletin de l'Institut Français d'Archéologie Orientale, 30 (1931), pp. 273-292.

Winter, M., “Saladin's Religious Personality, Policy and Image”, en Kraemer, J.L. (ed.), Perspectives on Maimonides. Philosophical and Historical Studies, Oxford, Littman Library of Jewish Civilization, 1996, pp. 309-322.

Yoвoue, A., La vision des ifranjs dans les chroniques arabes à l'époque ayyoubide (11741250), Tesis Doctoral, dir. John Tolan, Université de Nantes, en preparación.

Yovitchiтch, C., "An Early Ayyubid Fortification in the North of Jordan: 'Aljun Castle", International Conference on Islamic Fortification in Bilad al-Sam (Alepo, 16/19 septiembre de 2003), inédito.

Yovitchitch, C., "Les fortifications ayyoubides et mameloukes sur la route de Damas au Caire", Communication pour le Centre d'Étude d'Histoire de la Défense (Château de Vincennes, París, 13 de marzo de 2004), inédito.

Yovitchitch, C., "The Tower of Aybak in 'Ajlun Castle: An Exemple of the Spread of an Architectural Concept in Early $13^{\text {th }}$ Century Ayyubid Fortification", en KENNEDY, H. (dir.), Muslim Military Architecture in Greater Syria, Leiden, Brill, 2006, pp. 225-242.

Yoviтcнiтcн, C., Forteresses ayyoubides de la principauté de Damas: contribution à l'histoire des fortifications médiévales proche-orientales en terre d'Islam, Tesis Doctoral, dir. Marianne Barrucand, Université Sorbonne-Paris IV, 2007; pub. Forteresses du Proche-Orient, l'architecture militaire des Ayyoubides, París, Presses de l'Université Paris- Sorbonne, 2011.

Yovitchiтch, C., "La tour maîtresse dans la sphére ayyoubide: mirage ou réalité ?", Intervention pour le Conseil International des Monuments et de Sites, rencontre "Un patrimoine méditerranéen partagé: forteresses de l'époque des croisades” (Aigues Mortes, 26/27 de enero de 2007), inédito. 
Yovitchitch, C., "Die Befestigung der Tore aiyubidischer Burgen-Herausbildung eines Standards", en Piana, M. (ed.), Burgen und Städte der Kreuzzugszeit, Peterberg, Michael Imhof Verlag, 2008, pp. 110-117.

Yovitchiтch, C., "Die aiyubidische Burg 'Ajlun”, ibídem, pp. 118-125.

Yovitchitch, C., "Architecture militaire et représentation du pouvoir dans la Syrie ayyoubide (XIII ${ }^{\mathrm{e}}$ siècle)", $17^{\text {th }}$ Colloquium on the History of Egypt and Syria in the Fatimid, Ayyubid and Mamluk Eras (Gante, 14/16 de mayo de 2008), inédito.

Yovitchiтch, C., "Qal'at Najm and the Ayyubid Fortifications", Conférence pour l'Institut Français d'Études Annatoliennes dans le cycle "Fortifier un lieu, une ville, un territoire entre le $X^{e}$ et le XV siècles: exemples anatoliens et des villes voisines”, (Estambul, mayo de 2009), inédito.

Yoviтchiтch, C., "Hammams et fortifications: quelques remarques sur trois bains des périodes ayyoubide et mamelouke", Actes du colloque "Balaneia, thermes et hammams, 25 siècles de bain collectif (Proche-Orient, Egypte et Peninsule Arabique)”, (Damasco, 2/6 de noviembre de 2009), inédito.

Yovitchitch, C., "Les tours maîtresses ayyoubides", Histoire et images médiévales, 20 (2010), pp.26-33.

Zaman, M.S., "The Edification of Sir Walter Scott's Saladin in The Talisman", Studies in Literature and Language, 1/8 (2010), pp. 39-46.

Zeibi, A., Saladin. De l'histoire a la legende (XII ${ }^{e}-X V^{e}$ siècles), Tesis Doctoral, dir. Robert Deschaux, Université Stendhal-Grenoble 3, 1990.

Zounche, A., Armées et combats en Syrie de 491/1098 à 569-1174: analyse comparée des chroniques médiévales latines et arabes, Tesis Doctoral, dir. Thierry Blanquis, Université Lumiére-Lyon, 2005; pub. Damasco, Presses de l'Institut Français du Proche-Orient, 2008.

Zouache, A., "Saladin, l'histoire, la lègende", en Aigle, D. (dir.), Le Bilad al-Sam face aux mondes exterieurs. La perception de l'autre et la représentation du souverain, Beirut, Presses de 1'Institut Français du Proche-Orient, 2012, pp. 40-72.

Zouinal, M., Le pouvoir et les mystiques en Syrie et en Égypte de 1156 a 1275: étude sur la politique des princes et des sultans a l'égard des soufis, Tesis Doctoral, dir. Jean-Michel Mouton, École Pratique des Hautes Études, en preparación. 


\section{APÉNDICE I: RELACIÓN CRONOLÓGICA DE LOS PRINCIPADOS AYUBÍES Y SUS DIRIGENTES (589 H./1193-1194-658 H./1260-1261) ${ }^{163}$}

\section{EGIPTO}

589 H./1193-1194

595 H./1198-1199

596 H./1199-1200

615 H./1218-1219

635 H./1237-1238

637 H./1239-1240

647 H./1249-1250

648 H./1250-1251

655 H./1257-1258

657 H./1259-1260
al-'Azīz 'Uțman b. Șalāḥ al-Dīn (desde 582 H.)

al-Manșūr Muhammad b. al-'Azīz

al-'Ādil Abū Bakr Muḥammad b. Naŷm al-Dīn Ayyūb

al-Kāmil Muḥammad b. al-'Ādil (hasta 615 H. junto a al-'Ādil)

al-Kāmil Muhammad b. al-'Ādil

al-'Ādil Abū Bakr II b. al-Kāmil

al-Ṣâliḥ Ayyūb b. al-Kāmil

al-Mu'azżam Tūrānšāh b. al-Ṣālị̣

Šaŷar al-Durr (viuda de al-Șāliḥ) 'Izz al-Dīn Aybeg alTurkumānī (mameluco de al-Șâlị̣ y esposo de Šaŷar alDurr) al-Ašraf Mūsā b. Mas'ūd Yūsuf b. al-Kāmil (co-go bernante junto a 'Izz al-Dīn Aybeg hasta finales de 651 H./1253-1254) al-Manșūr 'Alī b. 'Izz al-Dīn Aybeg al-Muẓaffar Quțuz (mameluco de 'Izz al-Dīn Aybeg)

\section{DAMASCO}

589 H./1193-1194

592 H./1196-1197

594 H./1198-1199

615 H./1218-1219

624 H./1227-1228

626 H./1229-1230

$635 \mathrm{H} . / 1237-1238$

635 H./1237-1238

636 H./1238-1239

637 H./1239-1240

643 H./1245-1246

647 H./1249-1250
al-Afụal 'Alī b. Șalāḥ al-Dīn (¿desde 582 H.?)

al-'Ādil Abū Bakr Muhammad b. Naŷm al-Dīn Ayyūb (como representante de al-'Azīz de Egipto)

al-Mu'az̧zam 'Īsā b. al- 'Âdil (tutelado por al-'Ādil hasta $615 \mathrm{H}$.)

al-Mu'az̧̧am 'Īsā b. al-'Ādil (gobernante independiente)

al-Nāṣir Dāwūd b. al-Mu'az̧zam

al-Ašraf Mūsā b. al-'Ādil

al-Șālị̣ Ismā̄īl b. al-'Ādil (primer reinado)

al-Ŷ́awād Yūnus b. Šams al-Dīn Mawdūd b. al-'Ādil (como representante de al-'Ādil II de Egipto)

al-Șālih Ayyūb b. al-Kāmil Muhammad (primer reinado)

al-Șāliḥ Ismā̄īl b. al- 'Ādil (segundo reinado)

al-Ṣāliḥ Ayyūb b. al-Kāmil Muḥammad (representado en

Damasco por un lugarteniente) (segundo reinado)

al-Mu'aẓzam Tūrānšāh b. al-Șāliḥ Ayyūb

\footnotetext{
${ }^{163}$ Fuente: HUMPHREYS, R.S., From Saladin to the Mongols, the Ayyubids of Damascus, 1193-1260, Albany, University of New York Press, 1977. 
648 H./1250-1251

658 H./1260-1261

589 H./1193-1194

613 H./1216-1217

634 H./1236-1237

648 H./1250-1251

658 H./1260-1261

al-Nāṣir Yūsuf b. al-'Azīz Muhammad b. al-Zāhir Gāzī b. Șalāḥ al-Dīn

Conquista de los mongoles

\section{ALEPO}

al-Žāhir Gāzī b. Șalāḥ al-Dīn (desde 582 H./1186-1187)

al-'Azīz Muḥammad b. al-Z̄āhir Gāzi

al-Nāșir Yūsuf b. al-'Azīz Muhammad (hasta 640 H./12421243 bajo la tutela de su abuela Ḍayfa Jātūn bint al-'Ādil) (reside en Damasco desde 648 H./1250-1251)

al-Mu'azz̧amTūrānšāhb. Șalāḥal-Dīn(como representante de al-Nāṣir Yūsuf)

Conquista de los mongoles

\section{HOMS}

589 H./1193-1194

637 H./1239-1240

643 H./1245-1246

646 H./1248-1249

658 H./1260-1261

662 H./1263-1264

574 H./1178-1179

587 H./1191-1192

617 H./1220-1221

626 H./1229-1230

642 H./1244-1245

683 H./1284-1285

\section{HAMA}

al-Muŷāhid Šīrkūh b. Nāșir al-Dīn Muḥammad b. Asad alDīn Šīrkūh (desde 581 H./1185-1186)

al-Manșūr Ibrāhīm b. al-Muŷāhid al-Ašraf Mūsā b. al-Manșūr

al-Nāṣir Yūsuf b. al-'Azīz Muḥammad b. al-Zāạhir Gāzi b. Șalāh al-Dīn (Homs es anexionada a Alepo) al-Ašraf Mūsā b. al-Manșūr (segundo gobierno)

Mamelucos

Taqī l-Dīn 'Umar b. Šāhanšāh b. Naŷm al-Dīn Ayyūb al-Manșūr Muhammad b. Taqī l-Dīn 'Umar al-Nāșir Kiliç Arslan b. al-Manșūr al-Muẓaffar Maḥmūd b. al-Manșūr al-Manșūr Muḥammad II b. al-Muẓaffar al-Muẓaffar Maḥmūd b. al-Manșūr Muḥammad II 


\section{EDESA Y HARRAN (Diyār Muḍar) ${ }^{164}$}

589 H./1193-1194

592 H./1196-1197

597 H./1200-1201

615 H./1218-1219

$626 \mathrm{H} . / 1229-1230$

635 H./1237-1238

638 H./1240-1241

657 H./1259-1260
al-'Ādil Abū Bakr Muhammad b. Naŷm al-Dīn Ayyūb (desde 588 H./1192-1193)

al-Fā' 'iz Ibrāhīm b. al-'Ādil (como representante de al-'Ādil) al-Ašraf Mūsā b. al-'Ādil (hasta 615 H./1218-1219 tutelado por al-'Ādil)

al-Ašraf Mūsā b. al-'Ādil (gobernante independiente)

al-Kāmil Muhammad b. al-'Ādil

al-Șāliḥ Ayyūb b. al-Kāmil

al-Nāṣir Yūsuf b. al-'Azīz Muḥammad b. al-Zāāhir Gāzī de Alepo

Conquista de los mongoles

\section{MAYYAFARIQIN (Diyār Bakr) ${ }^{165}$}

589 H./1193-1194

592 H./1196-1197

596 H./1199-1200

607 H./1210-1211

615 H./1218-1219

618 H./1221-1222

642 H./1244-1245

658 H./1259-1260

629 H./1231-1232

635 H./1237-1238

636 H./1238-1239

638 H./1240-1241

647 H./1249-1250

\footnotetext{
164 Véase mapa 4.

165 Véase mapa 4.

166 Véase mapa 4.
}

al-'Ādil Abū Bakr Muḥammad b. Naŷm al-Dīn Ayyūb (desde $588 \mathrm{H}$.)

al-Kāmil Muhammad b. al-'Ādil (tutelado por al-'Ādil)

al-Awhad Ayyūb b. al-'Ādil (tutelado por al-'Ādil)

al-Ašraf Mūsā b. al-'Ādil (tutelado por al-'Ādil)

al-Ašraf Mūsā (gobernante independiente)

al-Muẓaffar Gāzī b. al-'Adil

al-Kāmil Muḥammad b. al-Muzaffar

Conquista de los mongoles

\section{AMIDA E ḤIṢN KAYFA (Diyār Bakr) ${ }^{166}$}

al-Ṣālih Ayyūb b. al-Kāmil b. al-'Ādil (como representante de al-Kāmil hasta 635 H./1237-1238)

al-Ṣālih Ayyūb b. al-Kāmil

al-Mu'az̧żam Tūrānšāh b. al-Ṣālih Ayyūb (como representante de al-Ṣālị̣ hasta 647 H./1249-1250)

Amida es ocupada por los seljúcidas de Rum al-Awḥad 'Abd 'Allāh b. al-Mu'azẓam (como representante de al-Mu'azzam hasta 648 H./1250-1251) 


\section{TRANSJORDANIA (Kerak) ${ }^{167}$}

589 H./1193-1194

594 H./1198-1199

615 H./1218-1219

624 H./1217-1218

647 H./1249-1250

648 H./1250-1251

$648 \mathrm{H}$.

661 H./1262-1263
al-'Ādil Abū Bakr Muḥammad b. Naŷm al-Dīn Ayyūb (desde 584 H./1188-1189)

al-Mu'azzam 'Īsā b. al-'Ādil (tutelado por al-'Ādil hasta $615 \mathrm{H}$.)

al-Mu'azẓam 'Īsā (gobernante independiente)

al-Nāșir Dāwūd b. al-Mu'azẓam

al-Șālih Ayyūb b. al-Kāmil b. al-'Ādil

al-Mu'az̧⿻コ一am Tūrānšāh b. al-Șāliḥ Ayyūb

al-Mugịt 'Umar b. al-'Ādil Abū Bakr II b. al-Kāmil Muḥammad

ocupación de los mamelucos

\section{BAALBEK}

575 H./1179-1178

587 H./1191-1192

627 H./1229-1230

635 H./1237-1238

644 H./1246-1247
'Izz al-Dīn Farrujšāh b. Šāhanšāh b. Naŷm al-Dīn Ayyūb al-Amŷad Bahramšāh b. 'Izz al-Dīn Farrujšāh b. Šāhanšāh al-Ašraf Mūsā b. al-'Ādil b. Naŷm al-Dīn Ayyūb al-Șālih Ismā‘īl b. al-'Ādil al-Ṣālị̣ Ayyūb b. al-Kāmil b. al-'Ādil (después Baalbek pierde su estatus autónomo)

\section{BANYAS}

al-'Azīz 'Uțmān b. al-'Ādil b. Naŷm al-Dīn Ayyūb al-Z̄āhir Gāzī b. al-'Azīz

al-Sa'īd Hasan b. al-'Azīz

al-Ṣālị Ayyūb b. al-Kāmil b. al-'Ādil (dependencia de Egipto)

647 H./1249-1250

658 H./1259-1260
al-Nāṣir Yūsuf b. al-'Azīz Muhammad b. al-Zāhir Gāzī (dependencia de Damasco)

al-Sa‘̄ì Hasan b. al-‘Azīz (segundo gobierno)

${ }^{167}$ Kerak fue el centro de un principado semiautónomo solamente bajo al-Nāșir Dāwūd tras la pérdida de Damasco en 626 H. y al-Mugīt 'Umar. Salvo en estos casos, fue siempre dependiente de una entidad mayor, normalmente, Damasco. 


\section{BOSRA}

589 H./1193-1194

592 H./1196-1197

615 H./1218-1219

644 H./1246-1247
al-Z̄āhir Jidr b. Șalāḥ al-Dīn

iqtā' incorporada al principado de Damasco al-Șāliḥ Ismā‘̄il b. al-‘Ādil b. Naŷm al-Din Ayyūb al-Ṣāliḥ Ayyūb b. al-Kāmil b. al-'Ādil (después Bosra pier de su estatus autónomo)

\section{YEMEN}

569 H./1173-1174

577 H./1181-1182

593 H./1197-1198

598 H./1201-1202

611 H./1214-1215

612 H./1215-1216

625 H./1227-1229
al-Mu'az̧żam Tūrānšāh b. Naŷm al-Dīn Ayyūb al-‘Azīz Z̄āhir al-Dīn Tugtigin b. Naŷm al-Dīn Ayyūb Mu'izz al-Dīn Ismā‘̄il b. al-'Azīz Zāhir al-Dīn al-Nāṣir Ayyūb b. al-'Azīz Zāhir al-Dīn al-Muẓaffar Sulaymān b. Šāhanšāh b. Taqī l-Dīn ‘Umar Rasúlies al-Mas'ūd Yūsuf b. al-Kāmil

\section{OTRAS POBLACIONES Y FORTALEZAS IMPORTANTES}

Salkhad: al-Afựal 'Alī b. Șalāḥ al-Dīn (592 H./1196-1197-598 H./1201-1202)

Samosata: al-Afựal ‘Alī b. Șalāḥ al-Dīn (596 H./1199-1200-622 H./1225-1226)

'Ayntab: al-Ṣāliḥ Aḥmad b. al-Z̄āhir Gāzī b. Șalāḥ al-Dīn (m. 650 H./1252-1253)

Qal'at Jabar: al-Ḥāfiz Arslanšah b. al-‘'̄dil b. Naŷm al-Dīn Ayyūb (m. 639 H./1241-1242)

Tell Bašir: al-Ašraf Mūsā b. al-Manșūr b. al-Muŷāhid Šīrkūh (646 H./1248-1249-658 H./1259-1260) 


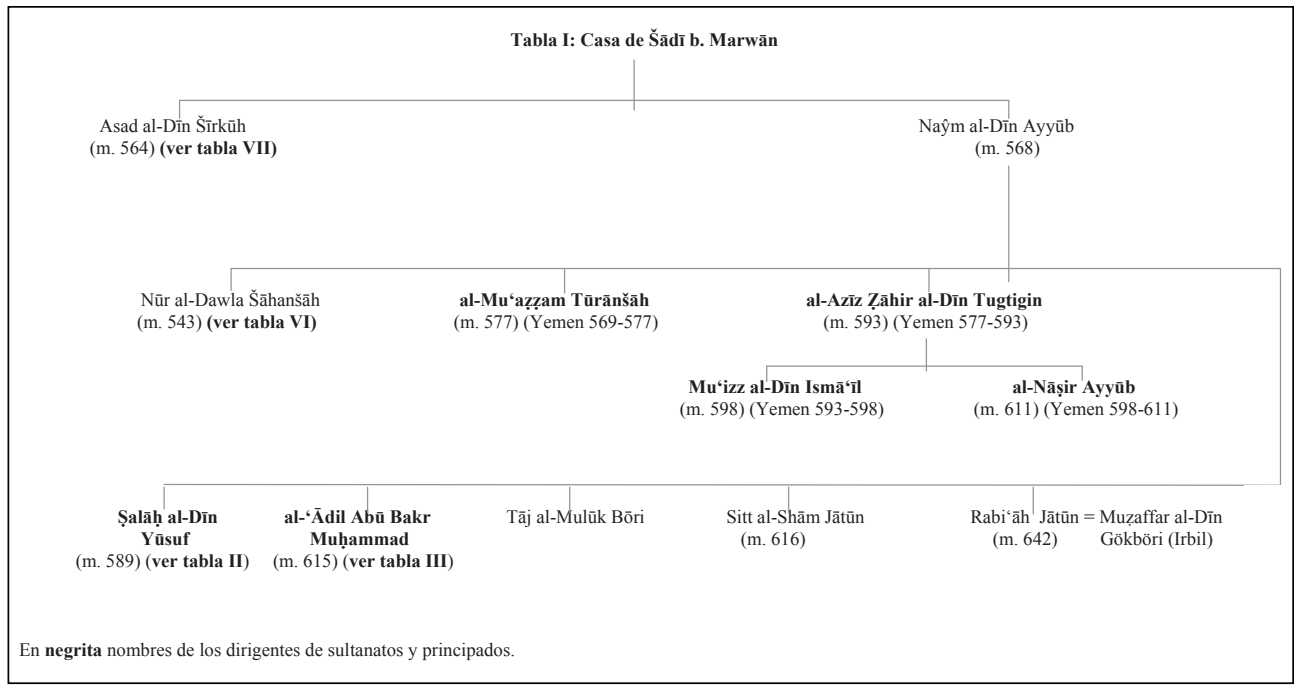

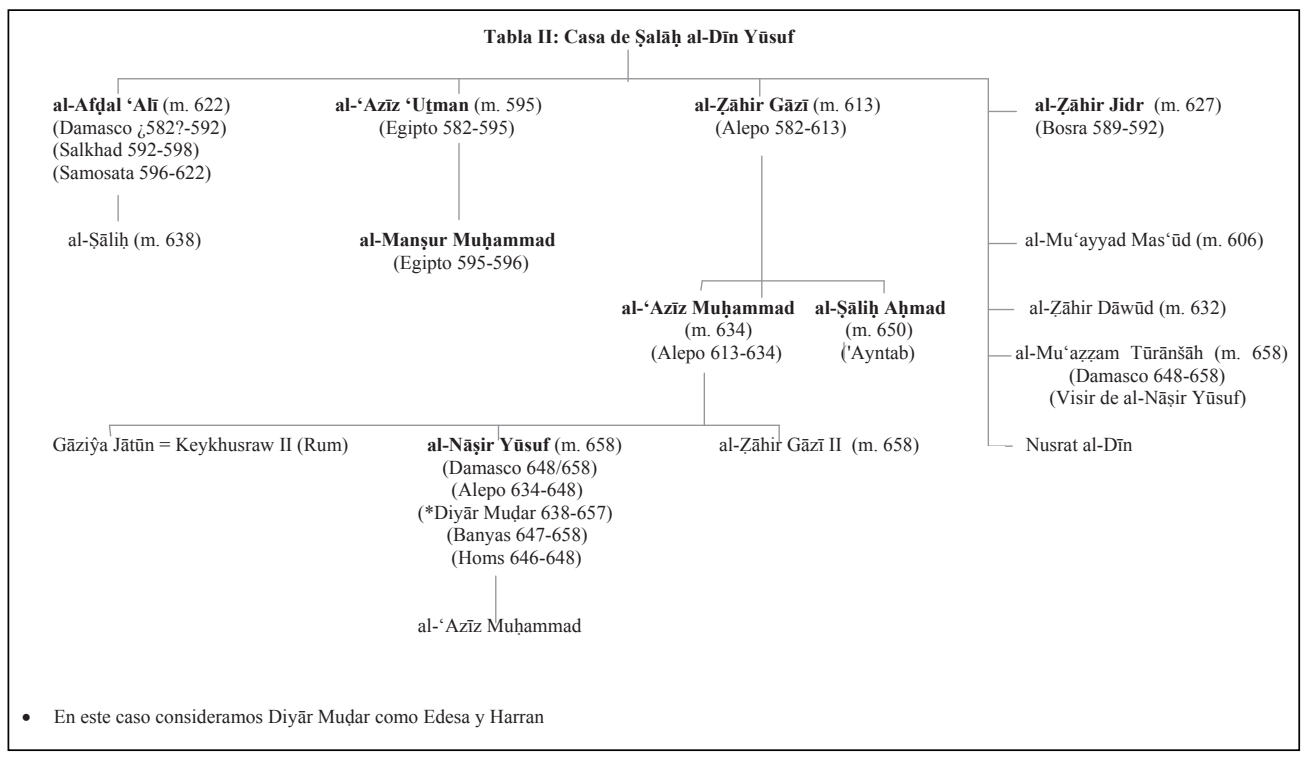




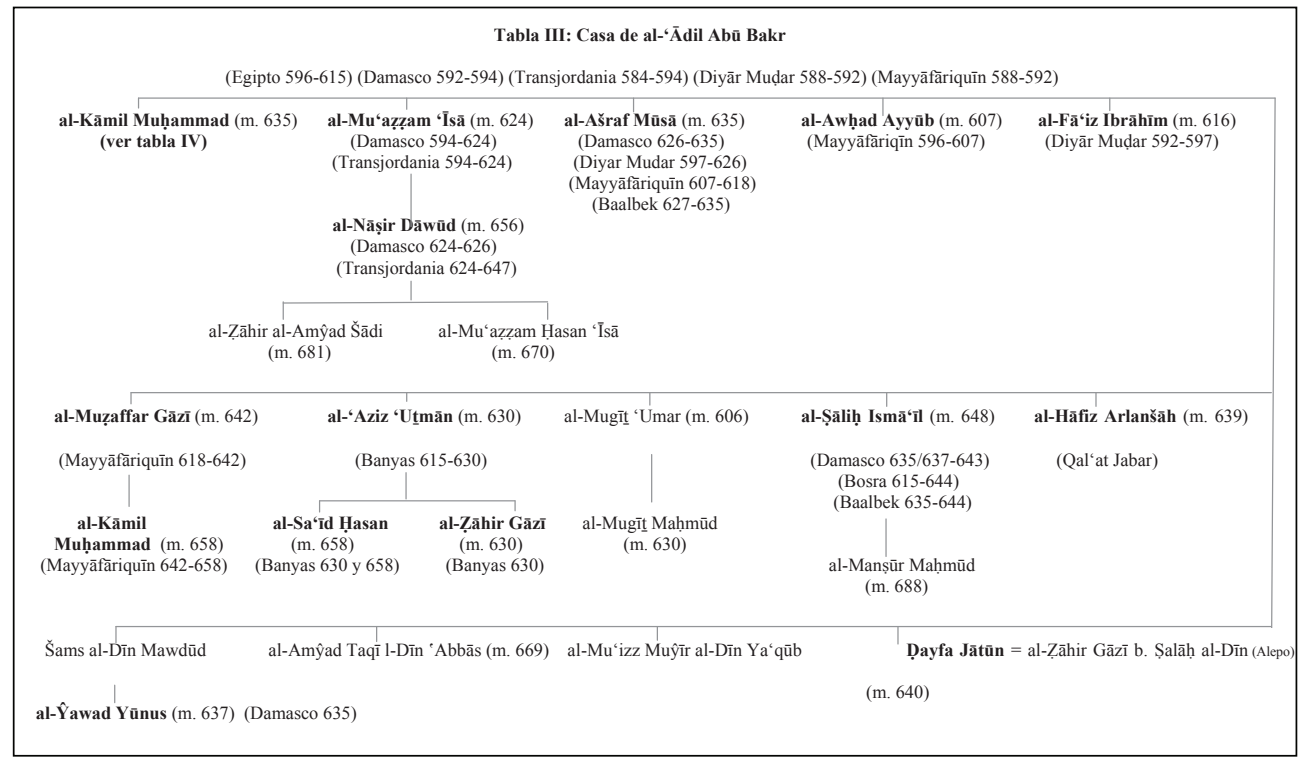

\begin{tabular}{|c|c|c|}
\hline \multirow{3}{*}{$\begin{array}{l}\text { al-Ṣāliḥ Ayyūb (m. 647) } \\
\text { (ver tabla V) }\end{array}$} & \multicolumn{2}{|c|}{$\begin{array}{l}\text { Tabla IV: Casa de al-Kāmil Muhammad } \\
\text { (Egipto 596-635) (Diyār Muḍar 626-635) (Mayyāaāriquīn 592-596) }\end{array}$} \\
\hline & $\begin{array}{l}\text { al-'Ādil Abū Bakr II (m. 645) } \\
\text { (Egipto 635-637) }\end{array}$ & $\begin{array}{l}\text { al-Mas'ūd Yūsuf (m. 625) } \\
\text { (Yemen 612-625) }\end{array}$ \\
\hline & $\begin{array}{l}\text { al-Mugīt ‘'Umar (m. 661) } \\
\text { (Transjordania 648-661) }\end{array}$ & $\begin{array}{l}\text { al-Ašraf Mūsā } \\
\text { (Egipto 648-651) }\end{array}$ \\
\hline Fāțima Jātūn = al-'Azīz Muhamma & \multicolumn{2}{|c|}{ 'Āšurā Jātūn = al-Nāșir Dāwūd b. al-Mu'azzzam (Transjordania } \\
\hline
\end{tabular}

\section{Tabla V: Casa de al-Ṣālị̣ Ayyūb}

(Egipto 637-647) (Damasco 636/643-647) (Bosra 644) (Banyas 644-647)

(Baalbek 644) (Transjordania 647) (Amida e Hișn Kayfa 629-636) (Diyār Muḍar 635-638)

Šâ̂ar al-Durr = 'Izz al-Dīn Aybeg al-Turkumānī (viuda de al-Șāliḥ) (mameluco de al-Șāliḥ Ayyūb)

$$
\text { (Egipto 648) (Egipto 648-655) }
$$

al-Mugīit 'Umar (m. 642)

al-Mu'azzam Tūrānšāh (m. 648)

(Egipto 647-648) (Transjordania 648)

(Amida e Ḥiṣn Kayfa 636-638) (Damasco 647) 


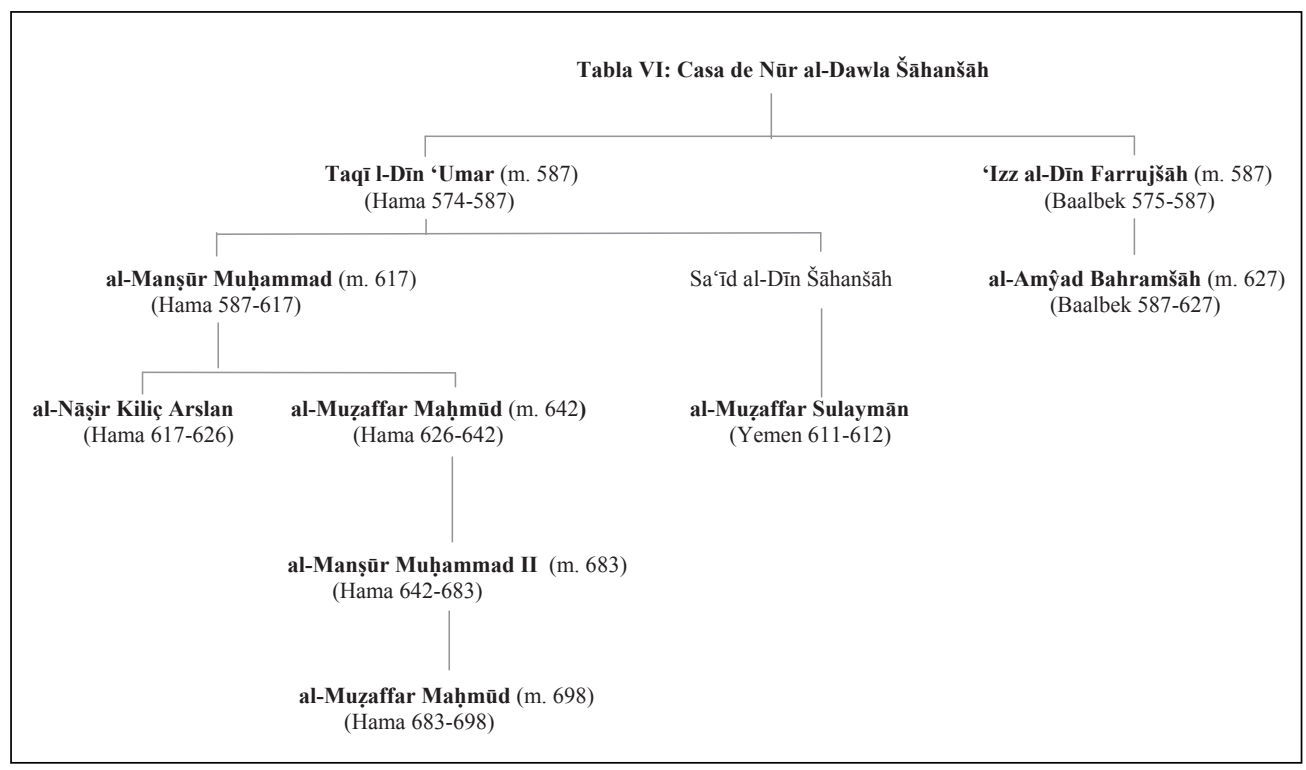

Tabla VII: Casa de Asad al-Dīn Šīrkūh

(Visir del califa fatimí de Egipto en 564)

Nāșir al-Dīn Muhammad (m. 581)

al-Muŷāhid S̄īkūh (m. 637)

(Homs 581-637)

al-Manșūr Ibrāhīm (m. 644)

(Homs 637-643)

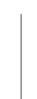

al-Ašraf Mūsā (m. 662)

(Homs 643-646 y 658-662) (Tell Bašir 646-658)
al-Șālih Nūr al-Dīn Ismā‘n̄l (m. 658) 

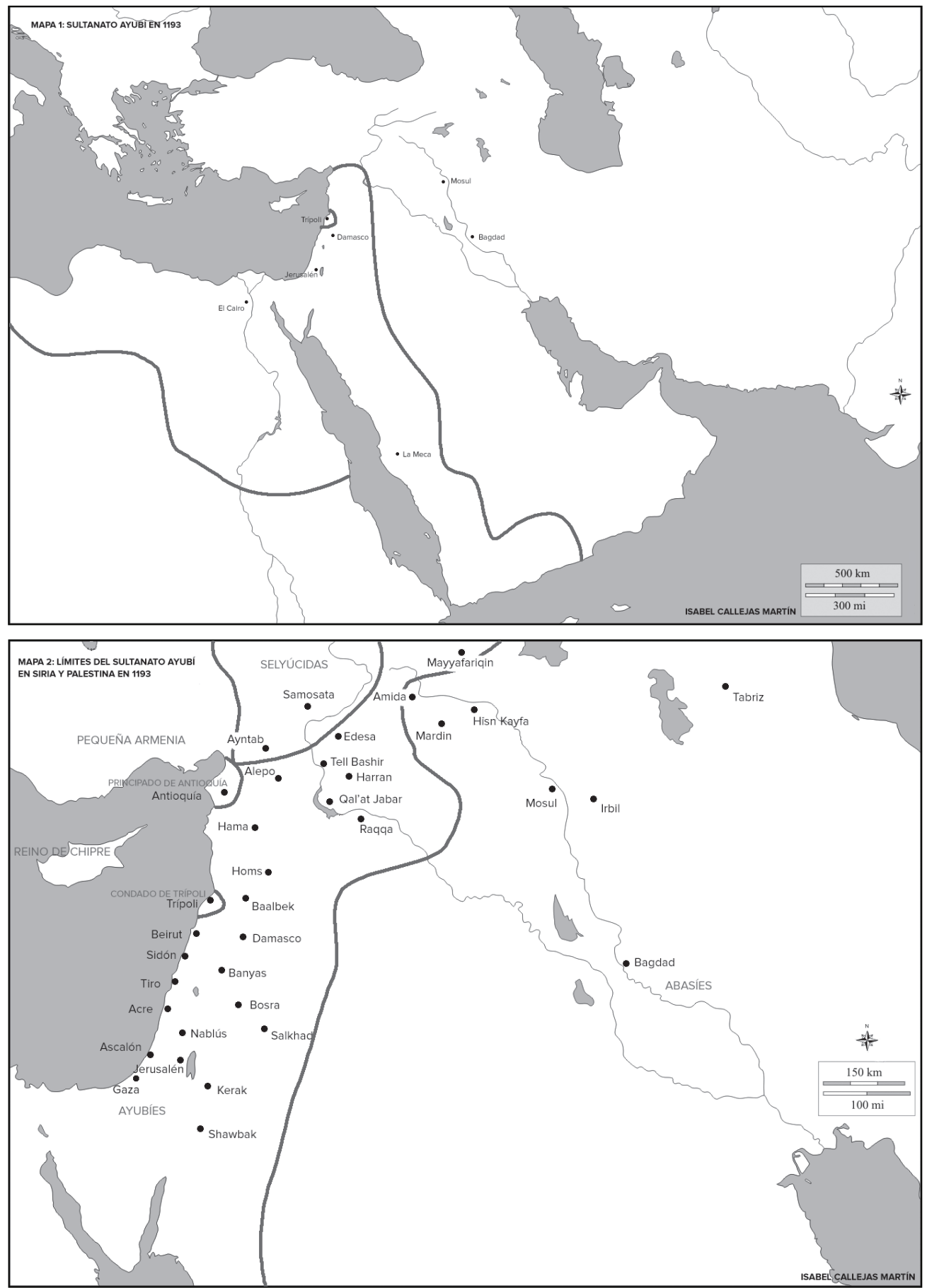

Fuentes: HUMPHREYS, R.S., From Saladin to the Mongols, pp. 388-391; y LANEPOOLE, S., The Mohammedan Dinasties, pp. 77-79. 